
of Engineers ${ }_{\circledast}$ Engineer Research and Development Center

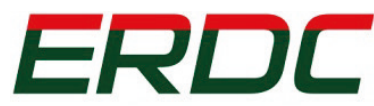
INNOVATIVE SOLUTIONS for a safer, better world

Monitoring Completed Navigation Projects (MCNP) Program

\title{
Use of Dolos Armor Units to Repair Hurricane Sandy-Damaged Great Lakes Harbor Breakwaters
}

Michael C. Mohr, Gerlyn J. Hinds, Weston P. Cross,

Shanon A. Chader, and Jeffrey A. Melby

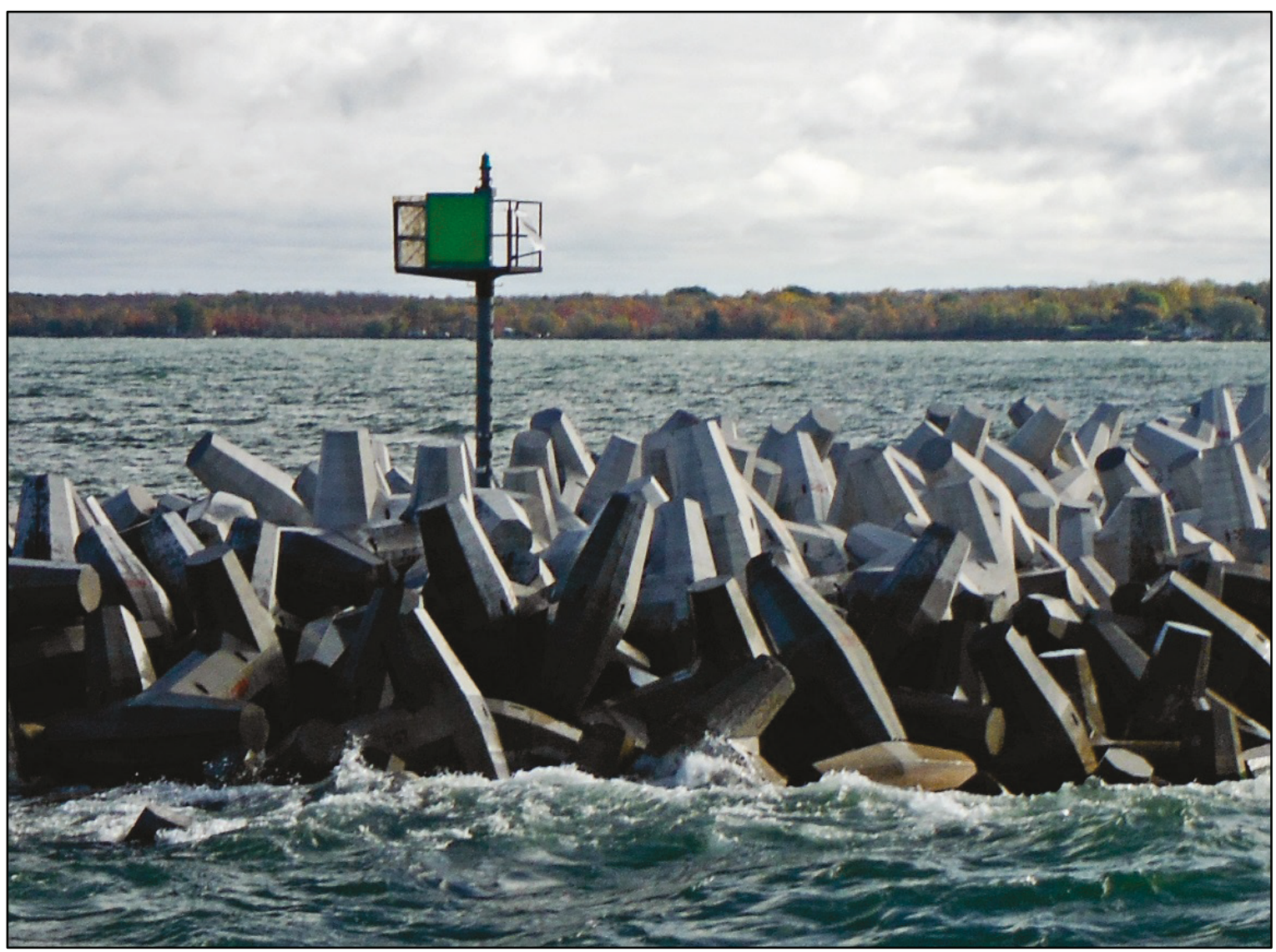


The U.S. Army Engineer Research and Development Center (ERDC) solves the nation's toughest engineering and environmental challenges. ERDC develops innovative solutions in civil and military engineering, geospatial sciences, water resources, and environmental sciences for the Army, the Department of Defense, civilian agencies, and our nation's public good. Find out more at www.erdc.usace.army.mil.

To search for other technical reports published by ERDC, visit the ERDC online library at http://acwc.sdp.sirsi.net/client/default. 


\section{Use of Dolos Armor Units to Repair Hurricane Sandy-Damaged Great Lakes Harbor Breakwaters}

Michael C. Mohr, Gerlyn J. Hinds, Weston P. Cross, and Shanon A. Chader

U.S. Army Corps of Engineers

1776 Niagara Street

Buffalo, NY 14207-3199

Jeffrey A. Melby

U.S. Army Engineer Research and Development Center Coastal and Hydraulics Laboratory

3909 Halls Ferry Road

Vicksburg, MS 39180-6199

Final report

Approved for public release; distribution is unlimited.

Prepared for U.S. Army Corps of Engineers

Washington, DC 20314-1000

Under Work Unit No. A1060 "Reliability Analysis of Coastal Structures" 


\section{Abstract}

After traveling up the eastern U.S. coastline, Hurricane Sandy made landfall on 29 October 2012 near Atlantic City, NJ, with winds of $80 \mathrm{mph}$. The backside of the storm moved inland, bringing high winds and rain far into the nation's interior. No longer a hurricane, but termed Superstorm Sandy, the winds were generally from the north over the Great Lakes, extending as far west as Lake Michigan, causing extensive damage to several federal harbor structures especially in the Lower Great Lakes, including Cleveland East Breakwater on Lake Erie and Oswego Detached Breakwater on Lake Ontario. Concrete dolos armor units were selected to repair damage on these two structures. During 2015, 6,919 6.5-ton unreinforced dolosse were placed, and an additional 11,340 dolosse were placed in 2016 on the Cleveland East Breakwater. During 2015, 973 16-ton steel-reinforced dolosse were placed on the Oswego Detached Breakwater. The dolos design process, creation of the forms, strength testing, and placement are described and documented. Knowledge gained from this initial placement and from future periodic monitoring will correlate dolos movement with environmental forces. This information will be used for reliability analysis of coastal structures in determining remaining useful life for asset-management funding prioritizations.

DISCLAIMER: The contents of this report are not to be used for advertising, publication, or promotional purposes. Citation of trade names does not constitute an official endorsement or approval of the use of such commercial products. All product names and trademarks cited are the property of their respective owners. The findings of this report are not to be construed as an official Department of the Army position unless so designated by other authorized documents. 


\section{Contents}

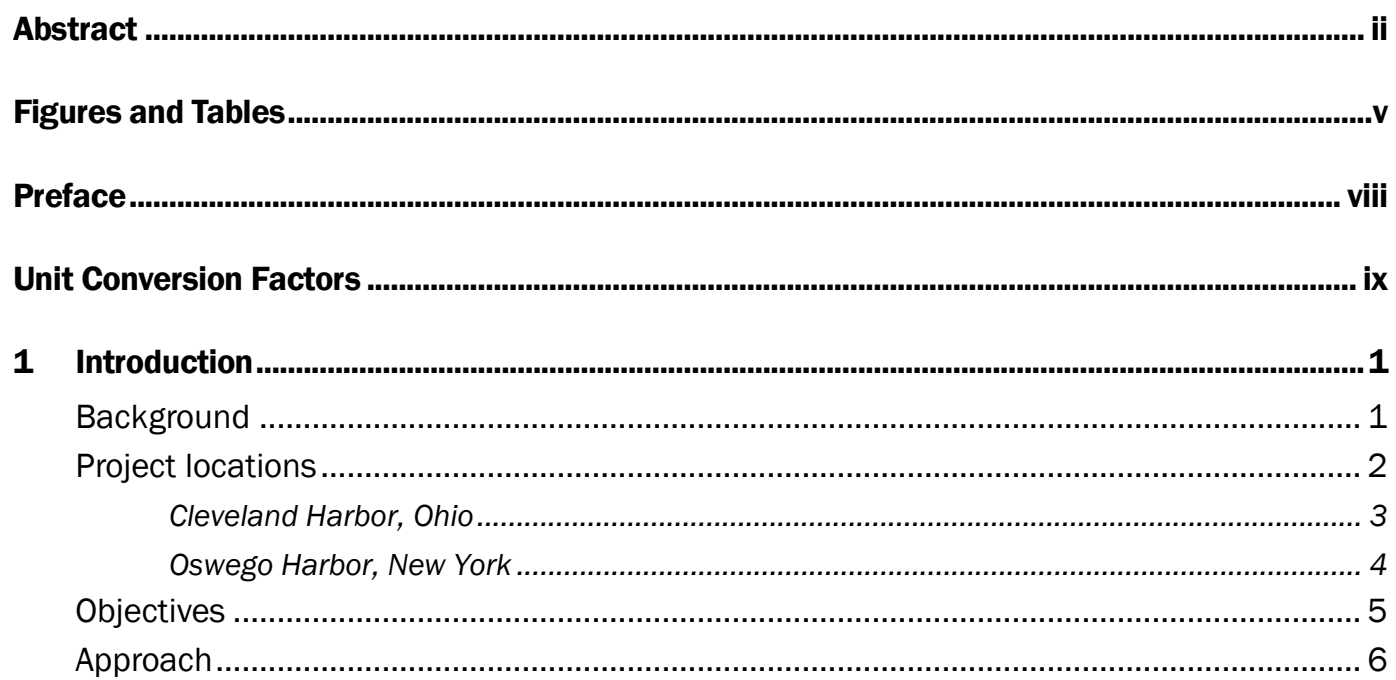

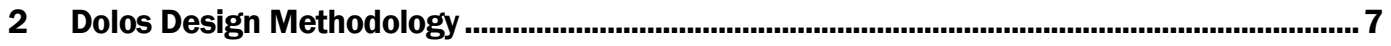

Water levels and waves ............................................................................................. 7

General

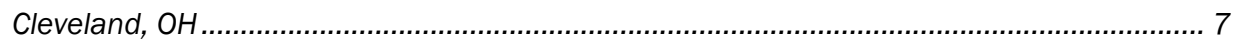

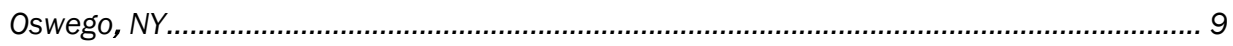

Dolos size and density ...................................................................................... 13

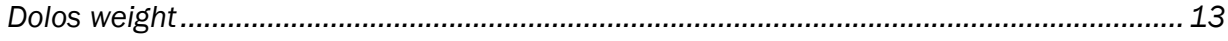

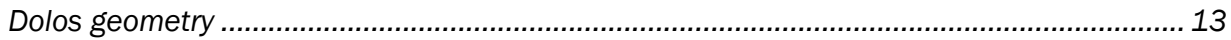

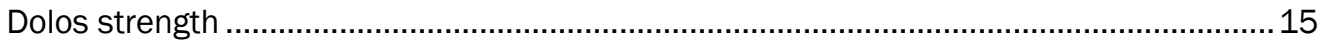

Typical sections and scale models ........................................................................... 17

3 Dolos Construction Techniques .........................................................................................21

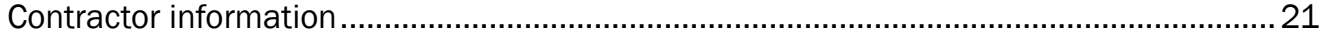

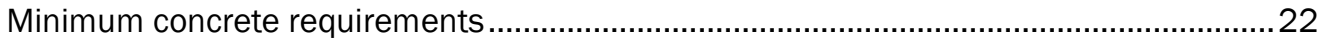

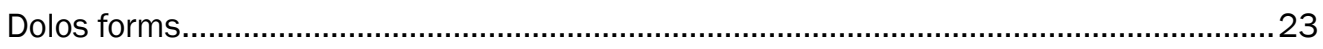

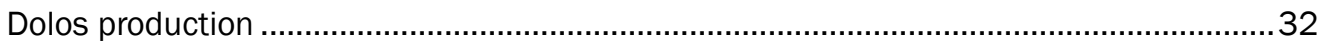

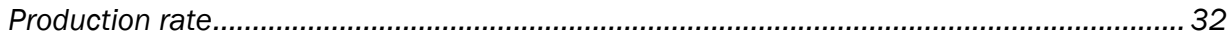

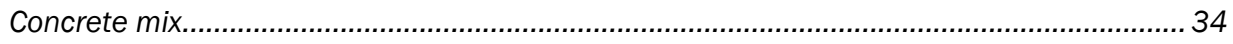

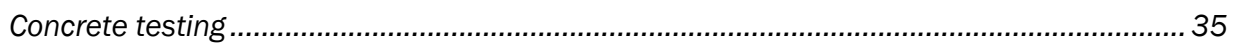

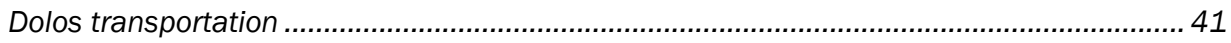

4 Dolos Placement Techniques ....................................................................................................43

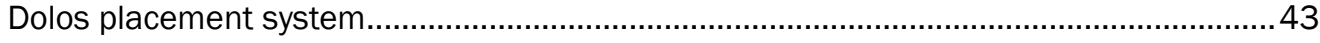

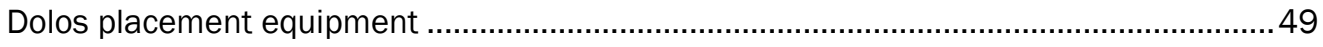

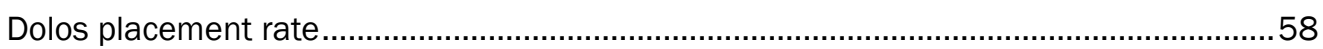

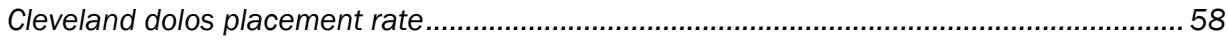

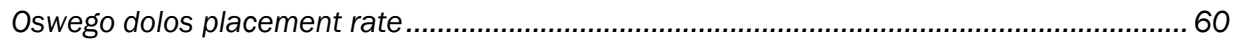

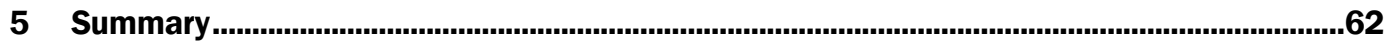




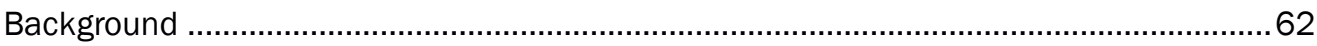

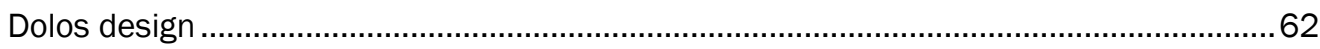

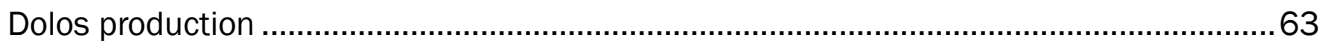

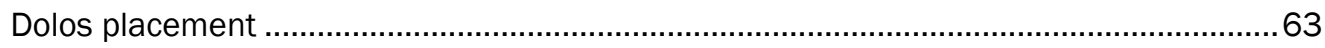

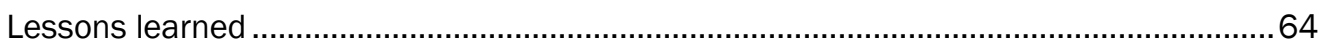

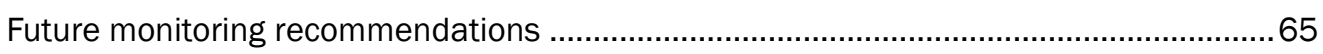

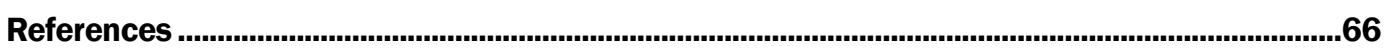

Report Documentation Page 


\section{Figures and Tables}

\section{Figures}

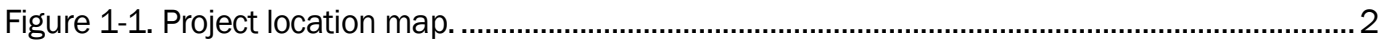

Figure 1-2. Cleveland Harbor repair location map..........................................................................

Figure 1-3. Cleveland East Breakwater section with 2-ton dolosse, 1979. ....................................... 4

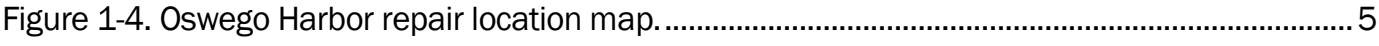

Figure 1-5. Oswego Detached Breakwater section, 1959................................................................. 5

Figure 2-1. WIS Hindcast Station 92070 location. .............................................................................. 8

Figure 2-2. WIS Hindcast Station 91042 location..........................................................................10

Figure 2-3. Oswego Detached Breakwater CMS-Wave monitoring stations. ......................................11

Figure 2-4. Non-dimensional schematic of typical dolos...................................................................14

Figure 2-5. Dolos weight versus maximum flexural tensile stress. .....................................................16

Figure 2-6. 16-ton dolos with steel reinforcement......................................................................17

Figure 2-7. Cleveland East Breakwater typical repair section with 6.5-ton dolosse. ..........................17

Figure 2-8. Oswego Detached Breakwater typical repair section with 16.0-ton dolosse....................18

Figure 2-9. Cleveland East Breakwater scale model..................................................................19

Figure 2-10. Oswego Detached Breakwater scale model with viewing window, side view................19

Figure 2-11. Oswego model, front view. ...................................................................................20

Figure 3-1. Constructing Cleveland 6.5-ton dolos forms. ...............................................................23

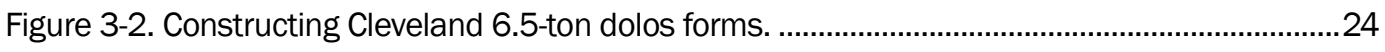

Figure 3-3. Completed Cleveland 6.5-ton dolos forms....................................................................2

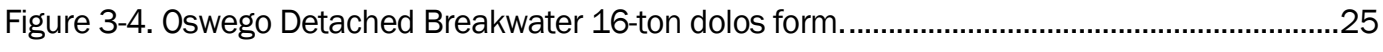

Figure 3-5. Oswego Detached Breakwater 16-ton dolos form...........................................................26

Figure 3-6. Placing concrete for Cleveland 6.5-ton dolos................................................................2

Figure 3-7. Loosening bolts and opening latches on Cleveland 6.5-ton dolos form...........................2

Figure 3-8. Opening Cleveland 6.5-ton dolos form fluke flaps............................................................28

Figure 3-9. Opening Cleveland 6.5-ton dolos form side wings. ........................................................2

Figure 3-10. Lifting Cleveland 6.5-ton dolos out of form. ................................................................29

Figure 3-11. Cleveland 6.5-ton dolos empty open form. ………………………………………....29

Figure 3-12. Lift method when moving Oswego 16-ton dolos........................................................30

Figure 3-13. Cutting Cleveland 6.5-ton dolos and cut sample. ……................................................31

Figure 3-14. Cutting Oswego 16-ton dolos and cut sample...........................................................31

Figure 3-15. Ground view of Allega Concrete forms and curing dolosse, June 2015........................32

Figure 3-16. Lakeland storage yard for Oswego 16-ton dolosse, February 2015.............................33

Figure 3-17. Minor modification to Oswego 16-ton dolos shape........................................................33

Figure 3-18. Cleveland dolos 28-day compressive strengths..........................................................36

Figure 3-19. Cleveland dolos 28-day flexural strengths. ……………………………...................38

Figure 3-20. Cleveland dolos flexural versus compressive with comparison to $\mathrm{ACl}$ equation 
Figure 3-21. Cleveland dolos 28-day flexural strength test (sample failed at 1,302 lb/in. ${ }^{2}$ ). ...........39

Figure 3-22. Oswego dolos quality assurance compressive test results......................................... 41

Figure 3-23. Dolosse at Port of Cleveland, Ohio............................................................................... 41

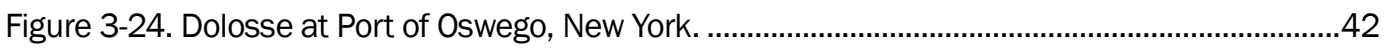

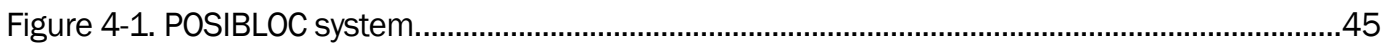

Figure 4-2. Crane operator's view of Oswego dolos placement. ...........................................................45

Figure 4-3. Crane operator's view of computer screen during Oswego dolos placement. ...............46

Figure 4-4. Cleveland Breakwater repair section definition of estimated quarter lengths................46

Figure 4-5. Cleveland plan of placed dolos centers of gravity.............................................................4 47

Figure 4-6. Allowable offsets for the placement of the first row of Oswego dolosse..........................48

Figure 4-7. Calibrating BIB on Oswego dolos.......................................................................................49

Figure 4-8. Cleveland dolos lifting arrangement............................................................................50

Figure 4-9. Aligning Cleveland dolos lifting mechanism with saddle (video time 0:00

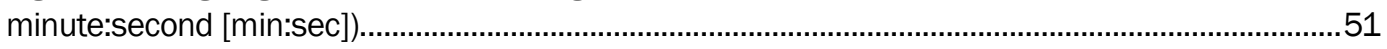

Figure 4-10. Removing saddle from Cleveland dolos prior to lifting (video time 0:21

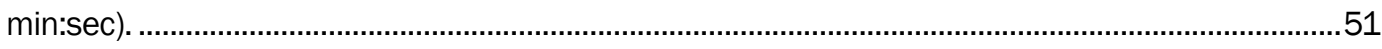

Figure 4-11. Placing saddle from Cleveland dolos at toe of section (video time 1:32 min:sec).

Figure 4-12. Cleveland dolos lifting mechanism returns for next dolos (video time 4:17

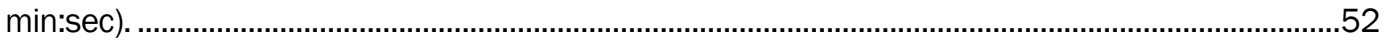

Figure 4-13. Next Cleveland dolos is being lifted for placement (video time 5:39 min:sec)............53

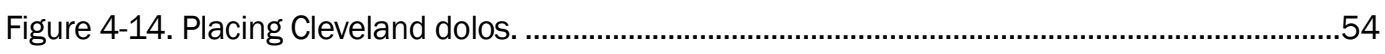

Figure 4-15. Oswego dolos lifting arrangement................................................................................54

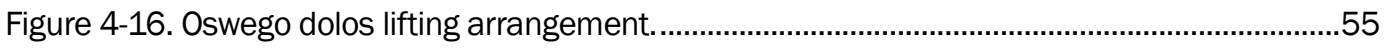

Figure 4-17. Cleveland dolos VISIBLOC placement view. ...................................................................56

Figure 4-18. Cleveland dolos VISIBLOC placement view. .................................................................57

Figure 4-19. Cleveland dolos VISIBLOC placement view. ..............................................................57

Figure 4-20. Cleveland dolos VISIBLOC placement view. .................................................................58

Figure 4-21. Cleveland 6.5-ton dolos placement rate....................................................................59

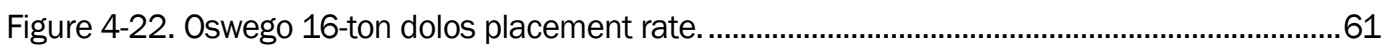

\section{Tables}

Table 2-1. Cleveland water levels and offshore waves. ...................................................................... 8

Table 2-2. Oswego water levels and offshore waves...........................................................................10

Table 2-3. Oswego Detached Breakwater incident waves..................................................................11

Table 2-4. Cleveland and Oswego dolos parameters (Figure 2-4)....................................................15

Table 3-1. Cleveland and Oswego minimum concrete requirements. ................................................22

Table 3-2. Cleveland 6.5-ton dolos concrete mix, $140 \mathrm{lb} / \mathrm{ft}^{3}$, no reinforcement..............................34

Table 3-3. Oswego 16-ton dolos concrete mix, $150 \mathrm{lb} / \mathrm{ft}^{3}$, steel reinforcement. ...............................34

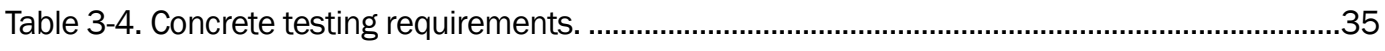

Table 3-5. Cleveland dolos 28-day compressive strength test statistics.............................................36 
Table 3-6. Cleveland dolos 28-day flexural strength test statistics. .................................................37

Table 3-7. Oswego dolos compressive strength tests greater than $5,000 \mathrm{lb} / \mathrm{in}^{2}{ }^{2}$............................40

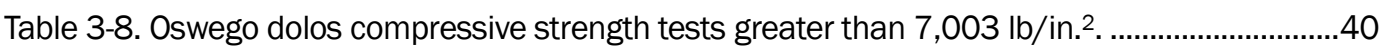

Table 4-1. Oswego first-row placement descriptive statistics. ............................................................49

Table 4-2. Cleveland 6.5-ton dolos daily placement rate statistics...................................................60 


\section{Preface}

This study was conducted for Headquarters, U.S. Army Corps of Engineers (HQUSACE), as part of the USACE Monitoring Completed Navigation Projects (MCNP) Program, under Work Unit "Reliability Analysis of Coastal Structures."

This study was executed by the Technical Services Division (CELRB-TD), Design Branch (CELRB-TD-D), Coastal and Geotechnical Engineering Section (CELRB-TD-DC), of the USACE Buffalo District (CELRB); and by the Harbors, Entrances, and Structures Branch (CEERD-HN-H), Navigation Division (CEERD-HN) of the U.S. Army Engineer Research and Development Center (ERDC), Coastal and Hydraulics Laboratory (CHL). During conduct of this study, Mr. Thomas Switala was Chief, CELRB-TD; Mr. Todd Kufel was Chief, CELRB-TD-D; Mr. Michael Mohr was Chief, CELRB-TD-DC; Mr. James Gutshall was Chief, CEERD-HN-H; and Dr. Jacqueline Pettway was Chief, CEERD-HN. Dr. Jeffrey A. Melby was the principal investigator of the "Reliability Analysis of Coastal Structures" work unit of the USACE MCNP Program being executed by ERDC CHL. Mr. Jeffrey A. McKee, Chief, HQUSACE Navigation Branch, was the Navigation Business Line Manager. Mr. W. Jeff Lillycrop, ERDC CHL, was the ERDC Technical Director for Civil Works and Navigation Research, Development, and Technology Transfer portfolio. Dr. Lyndell Z. Hales was the MCNP Program Manager.

At the time of publication of this report, Mr. Charles E. Wiggins was the Acting Chief of CEERD-HN, Mr. Jeffrey R. Eckstein was the Acting Director of ERDC CHL, and Dr. Jacqueline Pettway was the Acting Deputy Director of ERDC CHL.

COL Bryan S. Green was the Commander of ERDC, and Dr. David W. Pittman was the Director of ERDC. 


\section{Unit Conversion Factors}

\begin{tabular}{|l|c|l|}
\hline Multiply & By & To Obtain \\
\hline acres & 0.404686 & hectares \\
\hline cubic yards & 0.7646 & cubic meters \\
\hline feet & 0.3048 & meters \\
\hline gallons (U.S. liquid) & 3.785401 & liters \\
\hline inches & 2.54 & centimeters \\
\hline knots & 0.5144444 & meters per second \\
\hline miles (nautical) & 1,852 & meters \\
\hline miles (U.S. statute) & $1,609.347$ & meters \\
\hline miles per hour & 0.44704 & meters per second \\
\hline ounces (mass) & 28.3495 & kilograms \\
\hline pounds (force) per square inch & 6.894757 & kilopascals \\
\hline pounds (mass) & 0.453592 & kilograms \\
\hline pounds (mass) per cubic foot & 16.01846 & kilograms per cubic meter \\
\hline square feet & 0.09290304 & square meters \\
\hline square miles & $2.589998 \mathrm{E}+06$ & square meters \\
\hline tons (2,000 pounds, mass) & 907.1847 & kilograms \\
\hline
\end{tabular}




\section{Introduction}

\section{Background}

Hurricane Sandy originated as a tropical wave in the eastern Caribbean on 19 October 2012. It quickly developed into a tropical depression, and within 6 hours (hr), transitioned into a tropical storm that began to slowly travel westward. Tropical Storm Sandy was upgraded to a hurricane on 24 October 2012 when its maximum sustained winds reached 74 miles per hour (mph). Sandy made landfall in Jamaica on 24 October 2012. As it swept across the Bahamas, Sandy gained strength to become a Category 1 hurricane before turning north toward the U.S. coastline.

Hurricane Sandy slowly traveled northward along the eastern U.S. coastline before turning westward and making landfall in the United States on 29 October 2012, striking near Atlantic City, NJ, with winds of $80 \mathrm{mph}$. At one point, Sandy's hurricane-force winds extended up to 175 miles from its center, and tropical storm-force winds (39 mph) reached out as far as 485 miles.

As Hurricane Sandy traveled northward along the U.S. coastline, the backside counterclockwise rotation of the storm moved farther inland, bringing high winds and rain far into the nation's interior. No longer called a hurricane, Sandy was now termed a superstorm, with winds generally from the north over the Great Lakes, extending as far west as Lake Michigan, causing severe extensive damage to several harbor structures especially in the Lower Great Lakes.

Cleveland Harbor East Breakwater on Lake Erie, and Oswego Detached Breakwater on Lake Ontario, were severely damaged on the lake sides by wave and water level effects resulting from Sandy. It was subsequently determined that the Cleveland Harbor East Breakwater would be rehabilitated by using 6.5-ton dolosse ${ }^{1}$, and the Oswego Detached Breakwater would be repaired by using 16 -ton dolosse.

While the destruction wrought by Sandy was overwhelming, the repair of the damage suffered by these two U.S. Army Corps of Engineers (USACE)

${ }^{1}$ dolos (singular), dolosse (plural) 
coastal structures provided an opportunity for obtaining high-fidelity data and knowledge regarding design, construction, and placement of those dolosse. These data will be invaluable for use by the "Reliability Analysis of Coastal Structures" work unit of the USACE Monitoring Completed Navigation Projects (MCNP) Program in asset-management decisionmaking regarding the appropriate time and sequence for expending federal funds to rehabilitate USACE infrastructure. Potentially, future periodic resurveying can be conducted to gain information about remaining future life of the protection provided by the dolosse as settling and displacement occur during future storms and Great Lakes ice conditions.

This U.S. Army Engineer Research and Development Center (ERDC), Coastal and Hydraulics Laboratory (CHL), technical report describes the design methodology, construction, and experience of rehabilitating two harbor breakwaters located on Lakes Erie (Cleveland Harbor East Breakwater, Ohio) and Lake Ontario (Oswego Detached Breakwater, New York) using 6.5-ton and 16-ton dolos, respectively.

\section{Project locations}

Cleveland Harbor is located at the city of Cleveland, $\mathrm{OH}$, along the south shore of Lake Erie, at the mouth of the Cuyahoga River, 176 miles westerly from Buffalo, NY. Oswego Harbor is located at the city of Oswego, NY, along the southeast shore of Lake Ontario, 57 miles westerly from Rochester, NY (Figure 1-1).

Figure 1-1. Project location map.

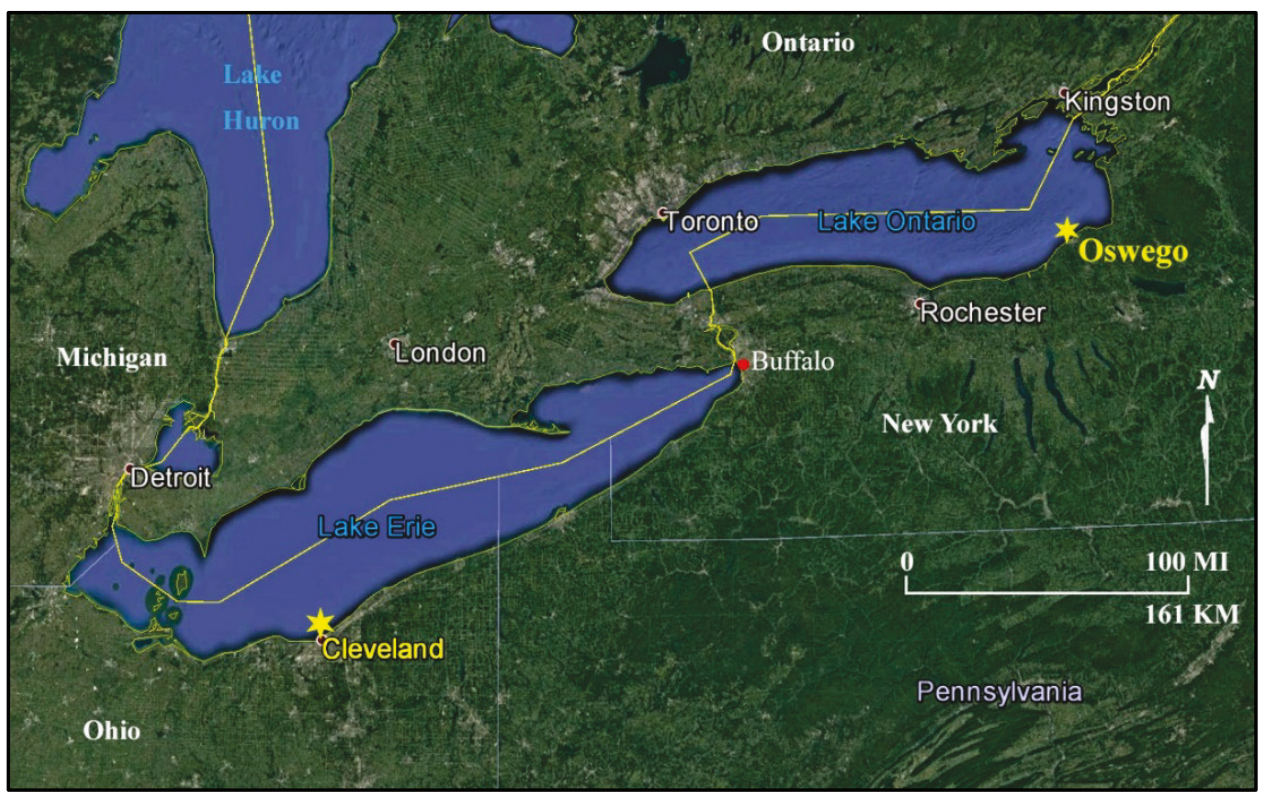




\section{Cleveland Harbor, Ohio}

Cleveland Harbor comprises an outer harbor 5 miles long enclosed by a series of breakwaters and piers with an aggregate length of approximately 5.5 miles as well as a federally maintained navigation channel extending approximately 5.25 miles up the Cuyahoga River. The East Breakwater at Cleveland Harbor was originally constructed between 1903 and 1915 and consisted of dumped core stone covered with individually placed large armor stone. The purpose of the East Breakwater is to reduce the severity of wave action within the harbor and allow ships to maneuver within the Cuyahoga River navigational channels during stormy weather. The East Breakwater has an extensive repair history utilizing multiple construction methods, including repair to the easterly 4,400 linear feet of the breakwater between 1979 and 1980 with 2-ton dolos armor units, with additional 4-ton units placed at the breakwater head in 1985-1986.

Significant breakage of these units occurred as the result of the storm, and the breakwater was repaired using dolosse. Figure 1-2 presents the harbor, and Figure 1-3 presents the typical section.

Figure 1-2. Cleveland Harbor repair location map.

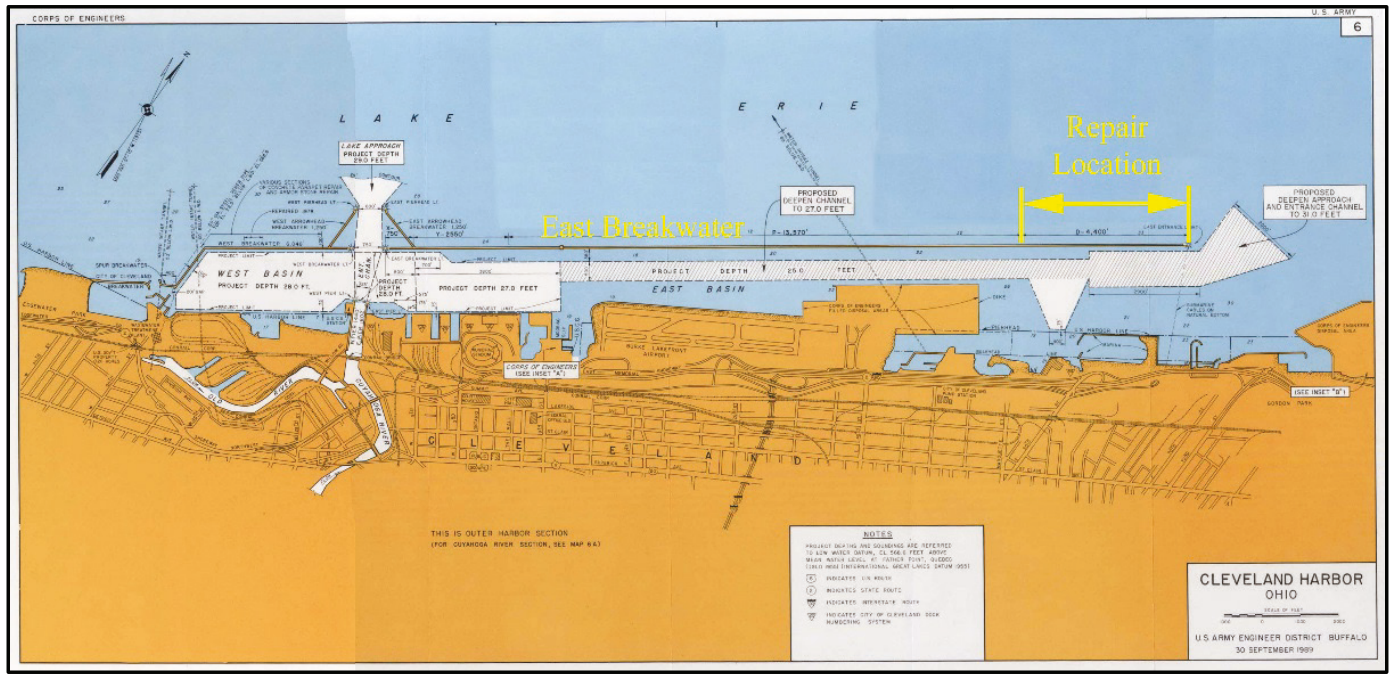


Figure 1-3. Cleveland East Breakwater section with 2-ton dolosse, 1979.

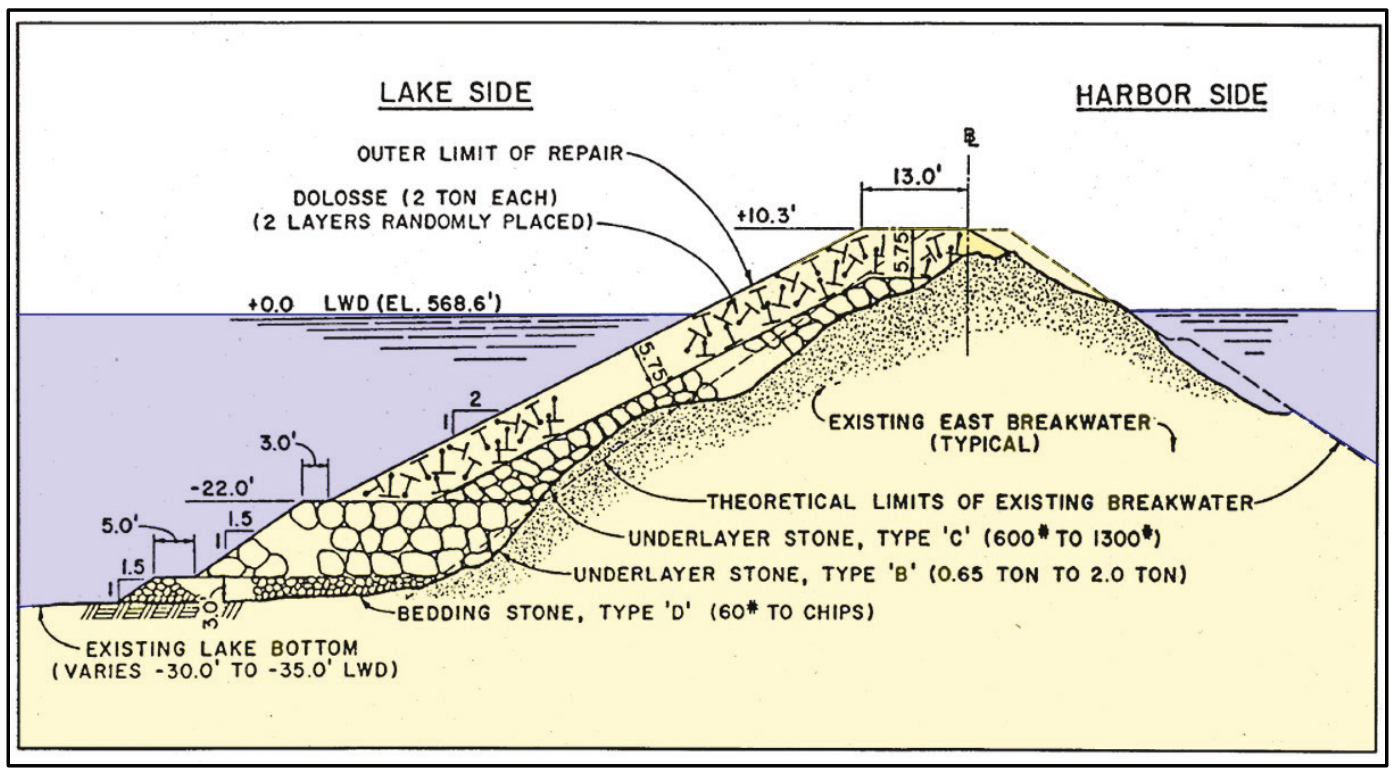

\section{Oswego Harbor, New York}

Oswego Harbor provides for an outer harbor, approximately 280 acres in area, formed by a system of breakwaters comprising an outer west breakwater 4,515 feet (ft) long connected with the shore, a west arrowhead breakwater 2,700 ft long, an east arrowhead breakwater approximately 2,200 ft long, and a detached breakwater $850 \mathrm{ft}$ long at the harbor entrance. It was the latter structure that received damage from Hurricane Sandy.

The detached breakwater is a laid-up cut stone structure built in 19581960. The cap is composed of cast-in-place concrete blocks $10 \mathrm{ft}$ long $\times 8 \mathrm{ft}$ wide. Light blocks, $8 \mathrm{ft} \times 8 \mathrm{ft} \times 4 \mathrm{ft}$, were cast in place at both ends to support U.S. Coast Guard light towers. The blocks do not rely fully for support by the surrounding stone; rather, they are each supported by four steel H-piles that were driven into the lake bed. The cast-in-place concrete cap extended another $12 \mathrm{ft}$ from these blocks. To make access to the breakwater crest and lights safer and easier, a concrete boat landing and stairs were also cast in place at the east end along the harbor side at the light block. The harbor map and typical detached breakwater cross section are presented in Figure 1-4 and Figure 1-5. 
Figure 1-4. Oswego Harbor repair location map.

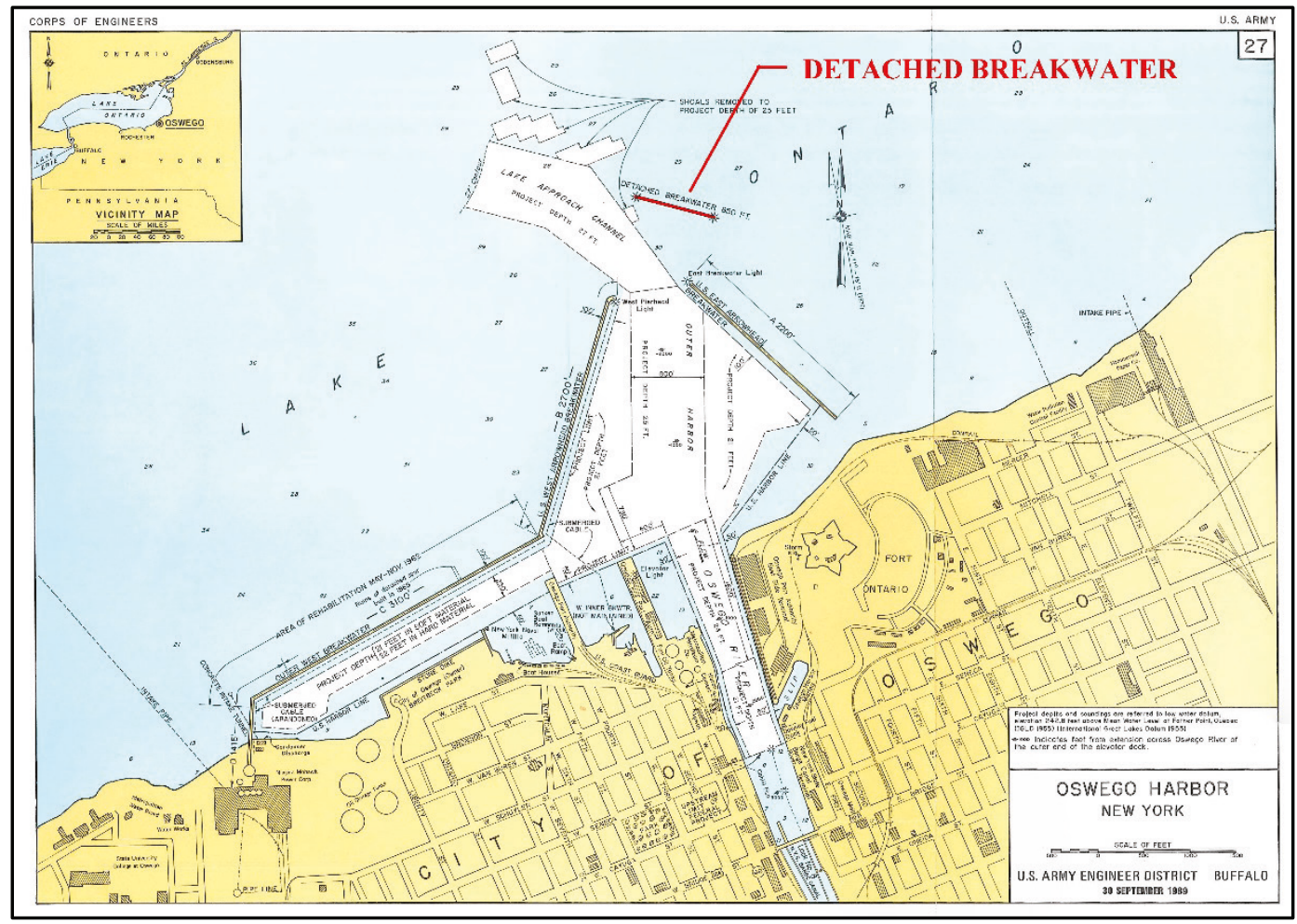

Figure 1-5. Oswego Detached Breakwater section, 1959.

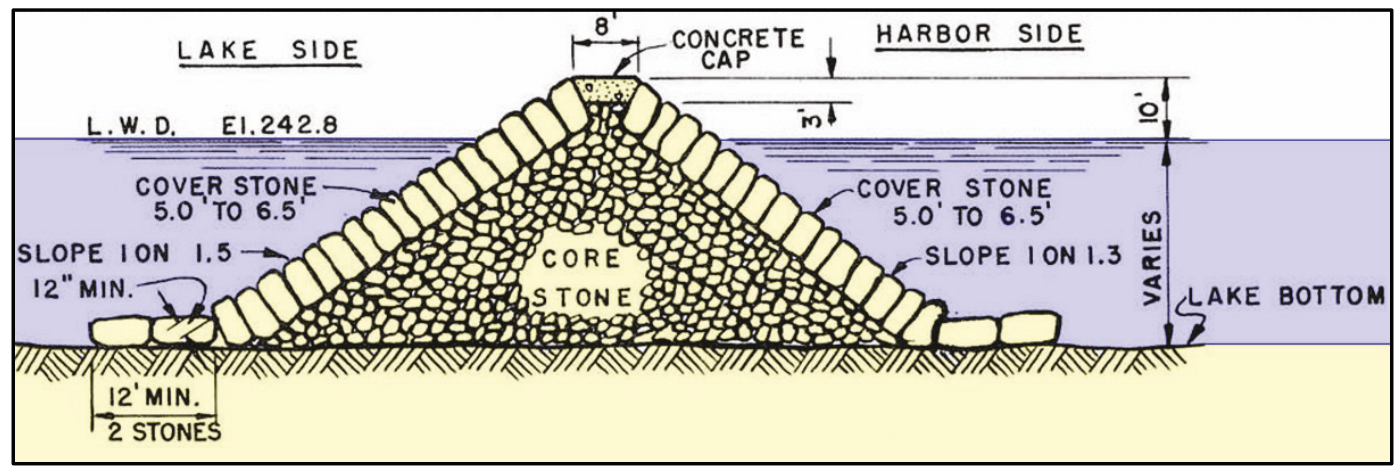

\section{Objectives}

The objectives of this ERDC CHL technical report are to present the design methodology, dolos construction, dolos placement, and lessons learned during the repair of two Great Lakes federal harbor breakwaters (Cleveland East Breakwater, Lake Erie; and Oswego Detached Breakwater, Lake Ontario). As the design methodology is fully discussed in the respective project Detailed Design Reports (USACE 2014b, 2014c, 2014d, 2014e), only pertinent information is extracted from those documents and presented herein. Interested readers are encouraged to peruse those documents for further details regarding the dolos design for these structures. 
The precise location of each dolos placed on the Cleveland East Breakwater (6.5-ton units) and the Oswego Detached Breakwater (16-ton units) will be known from the Armor Unit Placement and Positioning System (AUPPS [USACE Buffalo District term]). Periodic surveys of these breakwater repairs should be conducted on a 3- to 5-year interval to provide data for predicting future dolos movement. This will develop a high-fidelity estimate of remaining useful life of the structures based on the probability of future storm events as deduced by the Coastal Hazards Rapid Prediction System, which stores a suite of storm scenarios that cover a range of statistical events. This time-dependent damage modeling approach being developed by the MCNP Work Unit "Reliability Analysis of Coastal Structures" allows for the assessment of structure performance throughout the structure lifetime for a wide range of forcing and design conditions, knowledge that is of particular interest for asset-management funding prioritization.

\section{Approach}

This technical report is organized into five chapters. Chapter 1 "Introduction" presents background material leading to damages to the Cleveland East Breakwater and Oswego Detached Breakwater and describes the composition of these two structures. Chapter 2 "Dolos Design Methodology" reviews pertinent information from the Detailed Design Reports, including water levels and waves, dolos size and density, dolos strength, and typical sections and scale models of the structures. Chapter 3 "Dolos Construction Techniques" describes the minimum concrete requirements, fabrication of the dolos forms, and the dolos production. Chapter 4 "Dolos Placement Techniques" discusses the contractor AUPPS for the dolos placement, the contractor dolos placement equipment, and the contractor dolos placement rate. Chapter 5 "Summary" presents a brief review of the various necessary activities undertaken in producing and placing the dolos on the two structures, lessons learned, and future monitoring recommendations. 


\section{Dolos Design Methodology}

\section{Water levels and waves}

\section{General}

Standard design practice within the Great Lakes since the 1970s, and based upon practical experience, has been to use for the design conditions the greater of the combination of the 20-year wave and 10-year water level, or vice versa. Following this practice has resulted in reasonably sized structures that are resistant to wave and ice loadings. Lake level-frequency information within the Great Lakes has been developed (USACE 1993). Wave hindcast information at select locations for the Great Lakes is available from the ERDC CHL Wave Information Study (WIS) (USACE 2014a).

The $1 \mathrm{hr}$ deepwater significant wave height information was developed for three class angles. The three angle classes are defined as viewed by an observer on shore:

- Class Angle 1: Mean wave approach angle greater than 30 degrees (deg) to the right of the normal from shore.

- Class Angle 2: Mean wave approach angle within 30 deg to either side of the normal from shore.

- Class Angle 3: Mean wave approach angle greater than 30 deg to the left of the normal from shore.

The WIS storm data set was used to develop partial duration frequency curves for the three wave angle classes. The corresponding wave period was determined by plotting wave periods with the wave heights and fitting a best fit curve in EXCEL ${ }^{\mathrm{TM}}$. Incident waves at the structures were calculated using CMS-Wave (Lin et. al. 2008) for the case of the 10-year wave and 20-year water level, and vice versa, as well as for the 2-year wave and 2-year water level.

\section{Cleveland, $\mathbf{O H}$}

The U.S. National Oceanic and Atmospheric Administration (NOAA) maintains a water level gage at Cleveland Harbor, which has been in operation since 1904. Lake level-frequency information for Cleveland Harbor has been developed by the USACE, Detroit District (LRD), 
(USACE 1993). The wave hindcast developed along the Lake Erie shore encompasses the years 1979-2012. This data set was used to determine the design parameters for the hindcast location (92070) shown in Figure 2-1. CMS-Wave was run for the water level and deepwater wave conditions presented in Table 2-1 and indicated that the largest incident wave along the repair reach was $14.2 \mathrm{ft}$.

Figure 2-1. WIS Hindcast Station 92070 location.

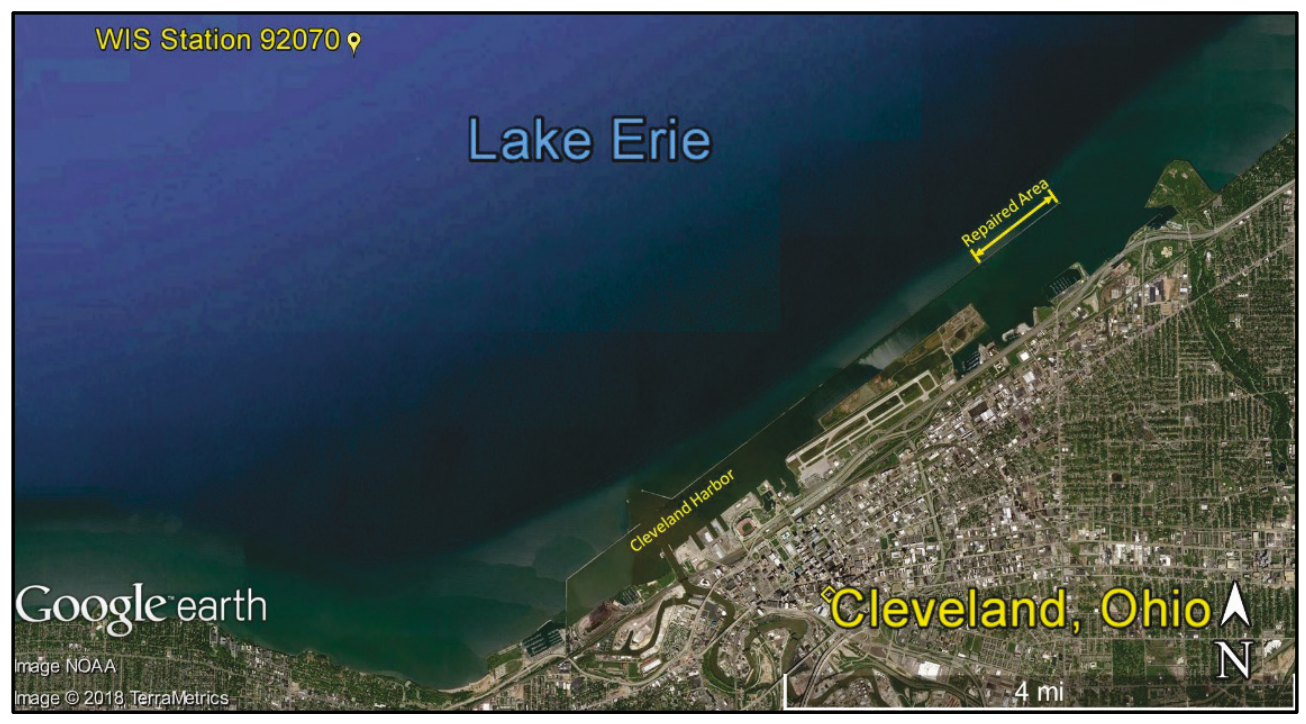

Table 2-1. Cleveland water levels and offshore waves.

\begin{tabular}{|c|c|c|c|c|c|c|c|}
\hline \multirow[b]{2}{*}{ Run } & \multicolumn{2}{|c|}{ Water Level } & \multicolumn{5}{|c|}{ Wave Characteristics } \\
\hline & $\begin{array}{l}\text { Low Water } \\
\text { Datum, ft }\end{array}$ & $\begin{array}{c}\text { Water Level } \\
\text { Recurrence Interval }\end{array}$ & $\begin{array}{c}\mathrm{H}_{\mathrm{mo}}, \\
\mathrm{ft}\end{array}$ & $\begin{array}{l}T_{p} \\
\text { sec }\end{array}$ & $\begin{array}{l}\text { Direction, deg, } \\
\text { Clockwise from North }\end{array}$ & $\begin{array}{l}\text { Wave Recurrence } \\
\text { Interval, years }\end{array}$ & $\begin{array}{l}\text { Wave } \\
\text { Angle } \\
\text { Class }\end{array}$ \\
\hline 1 & 4.5 & 2-year & 7.3 & 6.9 & 360 & 2 & 1 \\
\hline 2 & 4.5 & 2-year & 10.3 & 7.1 & 330 & 2 & 2 \\
\hline 3 & 4.5 & 2-year & 11.5 & 7.4 & 300 & 2 & 3 \\
\hline 4 & 5.8 & 10-year & 12.1 & 8.7 & 360 & 20 & 1 \\
\hline 5 & 5.8 & 10-year & 14.8 & 8.1 & 330 & 20 & 2 \\
\hline 6 & 5.8 & 10-year & 14.6 & 8.2 & 300 & 20 & 3 \\
\hline 7 & 6 & 20-year & 11.5 & 8.5 & 360 & 10 & 1 \\
\hline 8 & 6 & 20-year & 14.1 & 8 & 330 & 10 & 2 \\
\hline 9 & 6 & 20-year & 14.4 & 8.2 & 300 & 10 & 3 \\
\hline 10 & 0 & Low Water & 12.1 & 8.7 & 360 & 20 & 1 \\
\hline 11 & 0 & Low Water & 14.8 & 8.1 & 330 & 20 & 2 \\
\hline 12 & 0 & Low Water & 14.6 & 8.2 & 300 & 20 & 3 \\
\hline
\end{tabular}




\section{Oswego, NY}

NOAA maintains a water level gage at Oswego Harbor, New York. Lake level-frequency information for Oswego Harbor has been developed by USACE LRD (USACE 1993). The wave hindcast developed along the Lake Ontario shore encompasses the years 1979-2012. This data set was used to determine the design parameters, with the Hindcast Station (91042) shown in Figure 2-2. CMS-Wave was run for the water level and deepwater wave conditions presented in Table 2-2. Incident wave conditions at select locations (Figure 2-3) around the breakwater periphery are presented in Table 2-3 and indicated that the largest waves off the west head were $21 \mathrm{ft}$ and decreased along the length to $14 \mathrm{ft}$ at the eastern end. The large incident wave would result in prohibitively large armor, and with the attendant challenges of quarrying, transporting, and placing the armor, alternative armor types were investigated. Core-Loc ${ }^{\mathrm{TM}}$ or dolos concrete armor units were considered. Due to the compressed time frame associated with the availability of Hurricane Sandy funds and experience by ERDC, the use of Core-Loc was omitted as a hydraulic model study was deemed necessary to ensure their viability. Past U.S. Army Corps of Engineers, Buffalo District (LRB), experience with dolosse, and their use around the world, led LRB to choose dolosse as the preferred armor type at the west end. 
Figure 2-2. WIS Hindcast Station 91042 location.

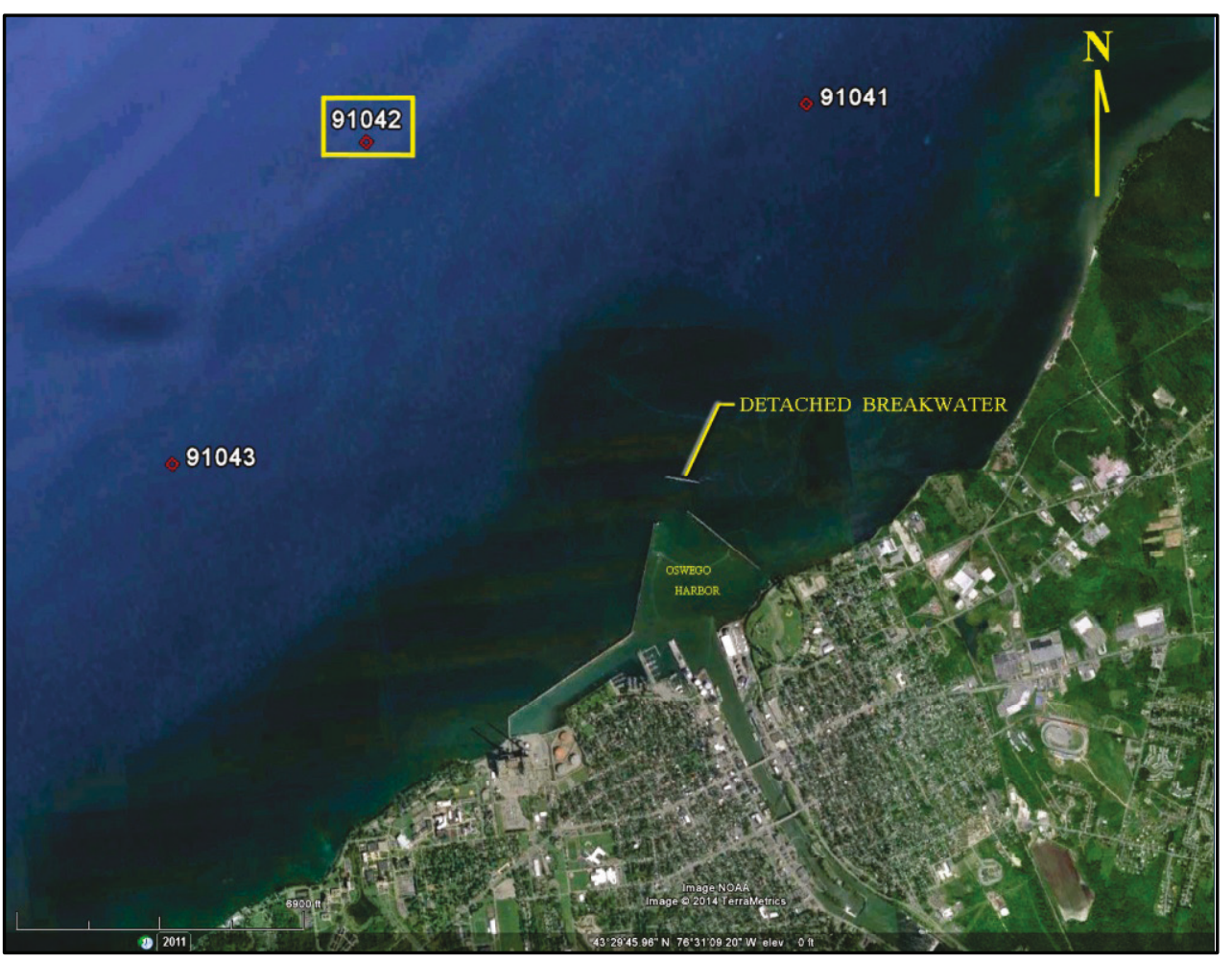

Table 2-2. Oswego water levels and offshore waves.

\begin{tabular}{|c|c|c|c|c|c|c|c|}
\hline \multirow[b]{2}{*}{ Run } & \multicolumn{2}{|c|}{ Water Level } & \multicolumn{5}{|c|}{ Wave Characteristics } \\
\hline & $\begin{array}{l}\text { Low Water } \\
\text { Datum, ft }\end{array}$ & $\begin{array}{c}\text { Water Level } \\
\text { Recurrence } \\
\text { Interval }\end{array}$ & $\mathrm{H}_{\mathrm{mo}}, \mathrm{ft}$ & $T_{p}, \sec$ & $\begin{array}{l}\text { Direction, deg, } \\
\text { Clockwise from } \\
\text { North }\end{array}$ & $\begin{array}{l}\text { Wave Recurrence } \\
\text { Interval, years }\end{array}$ & $\begin{array}{l}\text { Wave } \\
\text { Angle } \\
\text { Class }\end{array}$ \\
\hline 1 & 4.2 & 2-year & 12.1 & 7.5 & 356 & 2 & 1 \\
\hline 2 & 4.2 & 2-year & 12.3 & 8.1 & 326 & 2 & 2 \\
\hline 3 & 4.2 & 2-year & 23.3 & 8.2 & 296 & 2 & 3 \\
\hline 4 & 4.9 & 10-year & 14.8 & 8.2 & 356 & 20 & 1 \\
\hline 5 & 4.9 & 10-year & 14.0 & 8.7 & 326 & 20 & 2 \\
\hline 6 & 4.9 & 10-year & 26.6 & 12.9 & 296 & 20 & 3 \\
\hline 7 & 5.1 & 20-year & 14.6 & 8.1 & 356 & 10 & 1 \\
\hline 8 & 5.1 & 20-year & 13.6 & 8.6 & 326 & 10 & 2 \\
\hline 9 & 5.1 & 20-year & 25.9 & 12.7 & 296 & 10 & 3 \\
\hline 10 & 0 & Low Water & 14.8 & 8.2 & 356 & 20 & 1 \\
\hline 11 & 0 & Low Water & 14.0 & 8.7 & 326 & 20 & 2 \\
\hline 12 & 0 & Low Water & 26.6 & 12.9 & 296 & 20 & 3 \\
\hline
\end{tabular}


Figure 2-3. Oswego Detached Breakwater CMS-Wave monitoring stations.

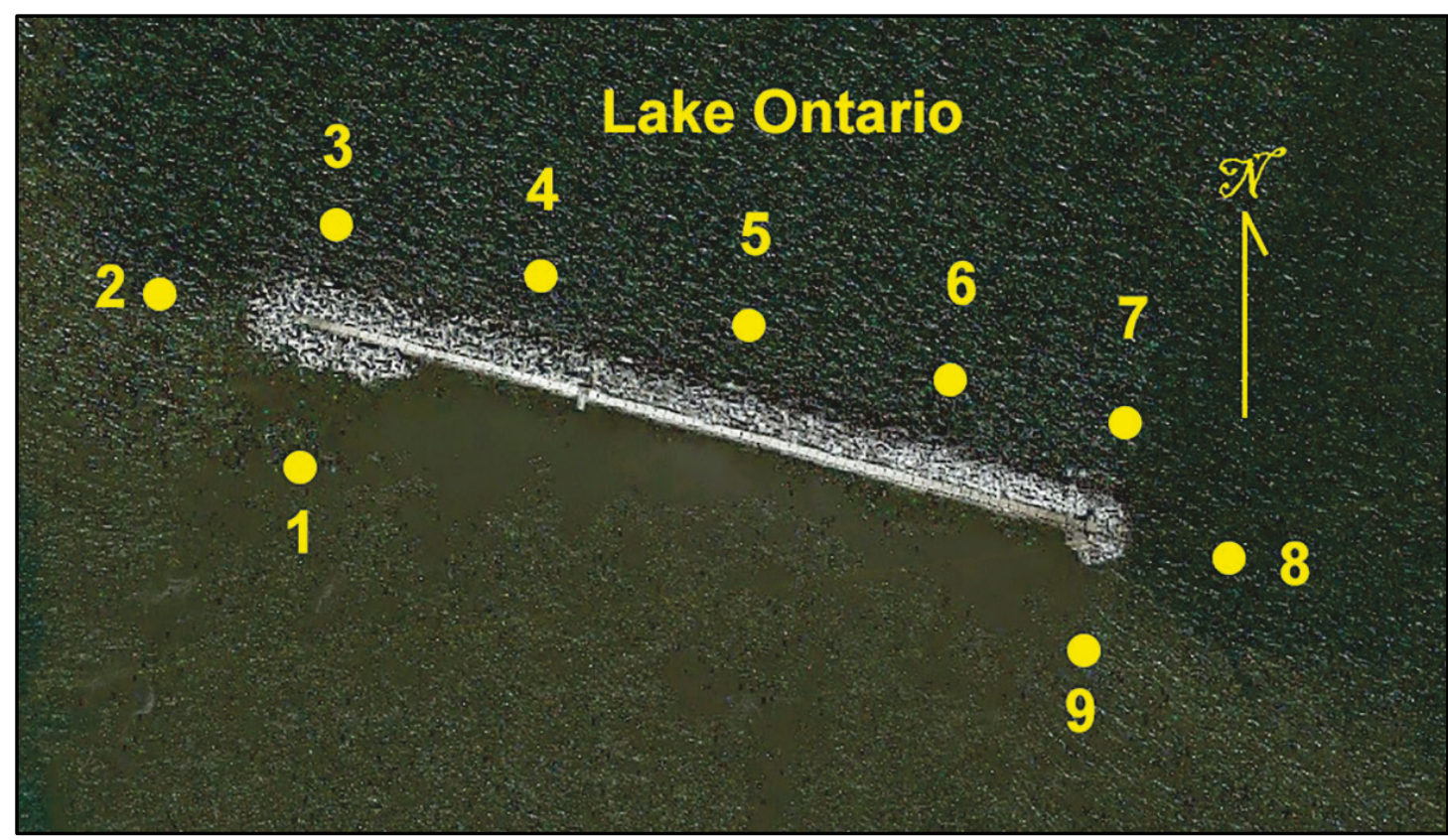

Table 2-3. Oswego Detached Breakwater incident waves.

\begin{tabular}{|l|c|c|c|c|c|l|}
\hline Location & Point & $\mathrm{H}_{\mathrm{s}, \mathrm{ft}}$ & $\mathrm{T}_{\mathrm{p}, \mathrm{sec}}$ & $\begin{array}{c}\text { Direction, } \\
\text { deg, } \\
\text { Clockwise } \\
\text { from North }\end{array}$ & $\begin{array}{c}\text { Low Water } \\
\text { Datum, } \\
\text { Water } \\
\text { Level, ft }\end{array}$ & Case \\
\hline West Head Lee & 1 & 9.2 & 8.3 & 334 & 4.9 & $\begin{array}{l}\text { RUN 4 - 10-year water level, 20-year } \\
\text { wave, class angle 1 }\end{array}$ \\
\hline West Head Lee & 1 & 12.2 & 8.3 & 309 & 4.9 & $\begin{array}{l}\text { RUN 5 - 10-year water level, 20-year } \\
\text { wave, class angle 2 }\end{array}$ \\
\hline West Head Lee & 1 & 17.7 & 11.1 & 289 & 4.9 & $\begin{array}{l}\text { RUN 6 - 10-year water level, 20-year } \\
\text { wave, class angle 3 }\end{array}$ \\
\hline West Head West & 2 & 12 & 8.3 & 334 & 4.9 & $\begin{array}{l}\text { RUN 4 - 10-year water level, 20-year } \\
\text { wave, class angle 1 }\end{array}$ \\
\hline West Head West & 2 & 13.1 & 8.3 & 316 & 4.9 & $\begin{array}{l}\text { RUN 5 - 10-year water level, 20-year } \\
\text { wave, class angle 2 }\end{array}$ \\
\hline West Head West & 2 & 21 & 11.1 & 296 & 4.9 & $\begin{array}{l}\text { RUN 6 - 10-year water level, 20-year } \\
\text { wave, class angle 3 }\end{array}$ \\
\hline West Head Lakeside & 3 & 13.9 & 8.3 & 344 & 4.9 & $\begin{array}{l}\text { RUN 4 - 10-year water level, 20-year } \\
\text { wave, class angle 1 }\end{array}$ \\
\hline West Head Lakeside & 3 & 11.5 & 8.3 & 313 & 4.9 & $\begin{array}{l}\text { RUN 5 - 10-year water level, 20-year } \\
\text { wave, class angle 2 }\end{array}$ \\
\hline West Head Lakeside & 3 & 20.2 & 11.1 & 293 & 4.9 & $\begin{array}{l}\text { RUN 6 - 10-year water level, 20-year } \\
\text { wave, class angle 3 }\end{array}$ \\
\hline Lakeside, 2+00 & 4 & 14.8 & 8.3 & 349 & 4.9 & $\begin{array}{l}\text { RUN 4 - 10-year water level, 20-year } \\
\text { wave, class angle 1 }\end{array}$ \\
\hline Lakeside, 2+00 & 4 & 11.5 & 8.3 & 322 & 4.9 & $\begin{array}{l}\text { RUN 5 - 10-year water level, 20-year } \\
\text { wave, class angle 2 }\end{array}$ \\
\hline
\end{tabular}




\begin{tabular}{|c|c|c|c|c|c|c|}
\hline Location & Point & $\mathrm{H}_{\mathrm{s}}, \mathrm{ft}$ & $T_{p}, \sec$ & $\begin{array}{l}\text { Direction, } \\
\text { deg, } \\
\text { Clockwise } \\
\text { from North }\end{array}$ & $\begin{array}{l}\text { Low Water } \\
\text { Datum, } \\
\text { Water } \\
\text { Level, ft }\end{array}$ & Case \\
\hline Lakeside, 2+00 & 4 & 16.9 & 11.1 & 306 & 5.1 & $\begin{array}{l}\text { RUN } 6 \text { - 10-year water level, 20-year } \\
\text { wave, class angle } 3\end{array}$ \\
\hline Lakeside, 4+00 & 5 & 15.1 & 8.3 & 352 & 4.9 & $\begin{array}{l}\text { RUN } 4 \text { - 10-year water level, 20-year } \\
\text { wave, class angle } 1\end{array}$ \\
\hline Lakeside, 4+00 & 5 & 11.8 & 8.3 & 326 & 4.9 & $\begin{array}{l}\text { RUN } 5 \text { - 10-year water level, 20-year } \\
\text { wave, class angle } 2\end{array}$ \\
\hline Lakeside, 4+00 & 5 & 15.4 & 11.1 & 312 & 5.1 & $\begin{array}{l}\text { RUN } 6 \text { - 10-year water level, 20-year } \\
\text { wave, class angle } 3\end{array}$ \\
\hline Lakeside, $6+00$ & 6 & 14.7 & 8.3 & 356 & 4.9 & $\begin{array}{l}\text { RUN } 4 \text { - 10-year water level, 20-year } \\
\text { wave, class angle } 1\end{array}$ \\
\hline Lakeside, $6+00$ & 6 & 12.2 & 8.3 & 329 & 4.9 & $\begin{array}{l}\text { RUN } 5 \text { - 10-year water level, 20-year } \\
\text { wave, class angle } 2\end{array}$ \\
\hline Lakeside, $6+00$ & 6 & 15.1 & 11.1 & 314 & 5.1 & $\begin{array}{l}\text { RUN } 6 \text { - 10-year water level, 20-year } \\
\text { wave, class angle } 3\end{array}$ \\
\hline East Head Lakeside & 7 & 13.6 & 8.3 & 357 & 4.9 & $\begin{array}{l}\text { RUN } 4 \text { - 10-year water level, 20-year } \\
\text { wave, class angle } 1\end{array}$ \\
\hline East Head Lakeside & 7 & 11.6 & 8.3 & 332 & 4.9 & $\begin{array}{l}\text { RUN } 5 \text { - 10-year water level, 20-year } \\
\text { wave, class angle } 2\end{array}$ \\
\hline East Head Lakeside & 7 & 13.9 & 11.1 & 319 & 5.1 & $\begin{array}{l}\text { RUN } 6 \text { - 10-year water level, 20-year } \\
\text { wave, class angle } 3\end{array}$ \\
\hline East Head East & 8 & 11.9 & 8.3 & 360 & 4.9 & $\begin{array}{l}\text { RUN } 4 \text { - 10-year water level, 20-year } \\
\text { wave, class angle } 1\end{array}$ \\
\hline East Head East & 8 & 9.6 & 8.3 & 338 & 4.9 & $\begin{array}{l}\text { RUN } 5 \text { - 10-year water level, 20-year } \\
\text { wave, class angle } 2\end{array}$ \\
\hline East Head East & 8 & 10.6 & 11.1 & 324 & 5.1 & $\begin{array}{l}\text { RUN } 6 \text { - 10-year water level, 20-year } \\
\text { wave, class angle } 3\end{array}$ \\
\hline East Head Lee & 9 & 6.4 & 8.3 & 10 & 4.9 & $\begin{array}{l}\text { RUN } 7 \text { - 20-year water level, 10-year } \\
\text { wave, class angle } 1\end{array}$ \\
\hline East Head Lee & 9 & 5.8 & 8.3 & 337 & 5.1 & $\begin{array}{l}\text { RUN } 8 \text { - 20-year water level, 10-year } \\
\text { wave, class angle } 2\end{array}$ \\
\hline East Head Lee & 9 & 7.6 & 11.1 & 303 & 5.1 & $\begin{array}{l}\text { RUN } 9 \text { - 20-year water level, 10-year } \\
\text { wave, class angle } 3\end{array}$ \\
\hline
\end{tabular}




\section{Dolos size and density}

\section{Dolos weight}

The required individual weight for the dolos was determined using Hudson (1958) ${ }^{1}$ :

$$
\boldsymbol{W}=\frac{\boldsymbol{W}_{\boldsymbol{r}} \boldsymbol{H}^{3}}{\boldsymbol{K}_{\boldsymbol{D}}\left(\boldsymbol{S}_{\boldsymbol{r}}-1\right)^{3} \cot \boldsymbol{\theta}}
$$

where:

$$
\begin{aligned}
\mathrm{W} & =\text { weight of armor unit in primary cover layer } \\
\mathrm{W}_{\mathrm{r}} & =\text { unit weight of armor } \\
\mathrm{H} & =\text { design wave height } \\
\mathrm{K}_{\mathrm{D}} & =\text { stability coefficient } \\
\mathrm{S}_{\mathrm{r}} & =\text { specific gravity of the armor unit } \\
\cot \theta & =\text { structure inverse slope. }
\end{aligned}
$$

Selection of the appropriate $K_{D}$ value is crucial to successfully sizing the dolos. Through consultation with coastal structure specialists at ERDC 2 , a $K_{D}$ value of 8 was selected. This value is based upon experience with structures around the world. With incident wave heights of 14.2 and $21.0 \mathrm{ft}$, unit weights of 140 pounds per cubic foot $(\mathrm{lb} / \mathrm{ft} 3)$ (no reinforcement) and $150 \mathrm{lb} / \mathrm{ft} 3$ (with steel reinforcement), the required individual dolos weights were determined as 6.5 tons and 16.0 tons for the Cleveland and Oswego repairs, respectively.

\section{Dolos geometry}

The geometric dimensions of the dolos have been normalized by the primary or characteristic length, C, as shown in Figure 2-4 (USACE 1984, 2011).

\footnotetext{
1 During the Oswego dolos design, Carver and Heimbaugh (1989) and Burcharth and Liu (1992) were also used and suggested weights of 16.1 and 13.6 tons, respectively. (USACE 2014c).

2 Jeffrey Melby (ERDC-CHL-MS) to Michael Mohr (CELRB-TD-DC), Subject: Dolos, personal communication, 18 March 2014.
} 
Figure 2-4. Non-dimensional schematic of typical dolos.

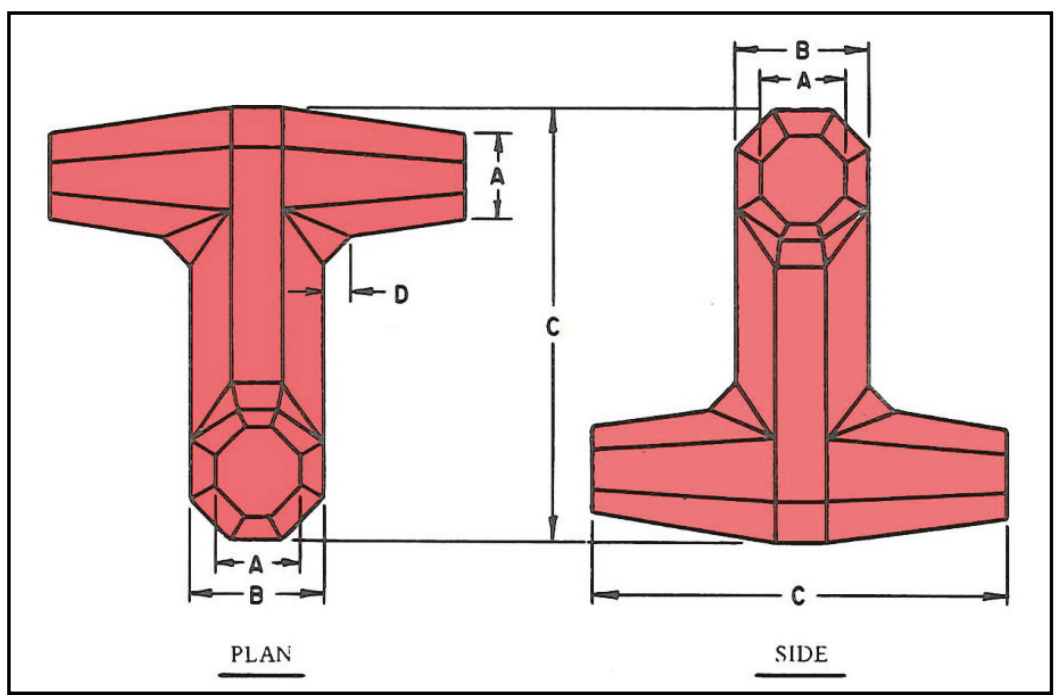

where:

$$
\begin{aligned}
& A=0.20 C \\
& B=0.32 C \\
& C=\text { overall dimension } \\
& D=0.057 C \\
& E=0.364 C .
\end{aligned}
$$

The volume, $V$, of an individual dolos can be expressed in terms of the characteristic length as

$$
V=0.16 C^{3}
$$

The layer thickness, $\mathrm{R}$, is

$$
\mathrm{R}=1.020 \mathrm{C}
$$

The number of dolosse per unit area, $N_{r}$, is

$$
N_{r}=0.83 V^{-\frac{2}{3}}
$$

Table 2-4 presents the adopted dolos parameters in feet (ft), square feet $\left(\mathrm{ft}^{2}\right)$, and cubic feet $(\mathrm{ft} 3)$. 
Table 2-4. Cleveland and Oswego dolos parameters (Figure 2-4).

\begin{tabular}{|l|c|c|}
\hline Variable & $\begin{array}{c}\text { Cleveland } \\
6.5 \text {-ton Dolos }\end{array}$ & $\begin{array}{c}\text { Oswego } \\
\text { 16-ton Dolos }\end{array}$ \\
\hline Dolos dimension, A & $1.67 \mathrm{ft}$ & $2.2 \mathrm{ft}$ \\
\hline Dolos dimension, B & $2.67 \mathrm{ft}$ & $3.52 \mathrm{ft}$ \\
\hline Dolos dimension, C & $8.33 \mathrm{ft}$ & $11.0 \mathrm{ft}$ \\
\hline Dolos dimension, D & $0.47 \mathrm{ft}$ & $0.6270 \mathrm{ft}$ \\
\hline Dolos dimension, $\mathrm{E}$ & $3.03 \mathrm{ft}$ & $4.00 \mathrm{ft}$ \\
\hline Layer thickness, $\mathrm{R}$ & $8.5 \mathrm{ft}$ & $11.22 \mathrm{ft}$ \\
\hline Volume, V & $92.5 \mathrm{ft}^{3}$ & $212.96 \mathrm{ft}^{3}$ \\
\hline Number units per area, $\mathrm{N}_{\mathrm{r}}$ & $40.6 / 1,000 \mathrm{ft}^{2}$ & $23.274 / 1,000 \mathrm{ft}^{2}$ \\
\hline
\end{tabular}

\section{Dolos strength}

Unreinforced concrete has a brittle failure mode. The maximum flexural tensile stress that the dolosse can be expected to experience during handling and placement was established using USACE (2011), Figure VI-544 (Figure 2-5), and resulted in a recommended value of 368 pounds per square inch (lb/in. $\left.{ }^{2}\right)$ (2.54 megapascals [MPa]) and $537 \mathrm{lb} /$ in. $^{2}$ (3.70 MPa) for the Cleveland and Oswego dolosse, respectively. The minimum precast compressive strengths, $f_{c}$, are $5,000 \mathrm{lb} /$ in. $^{2}$ and 10,000 lb/in. ${ }^{2}$ for Cleveland and Oswego, respectively. It would be prohibitively expensive or impractical to specify sufficient concrete tensile strength with the corresponding compressive strength to prevent breakage of the Oswego dolosse, and hence steel reinforcement was used. The analysis for the Oswego reinforcing steel may be found in USACE (2014d) and considered load cases of lifting by straps at the end of two flukes, in the center of the shaft, at the end of one fluke and around one end of the shaft. It was determined that a single point lift at an end of the fluke was not acceptable and hence not allowed as the reinforcement was unlikely to provide adequate strength for this load condition. The addition of the steel reinforcement resulted in a unit weight of $150.1 \mathrm{lb} / \mathrm{ft} 3$, consistent with the initial design assumption. Figure 2-6 presents a view of the 16-ton dolos with reinforcing steel. 
Figure 2-5. Dolos weight versus maximum flexural tensile stress.

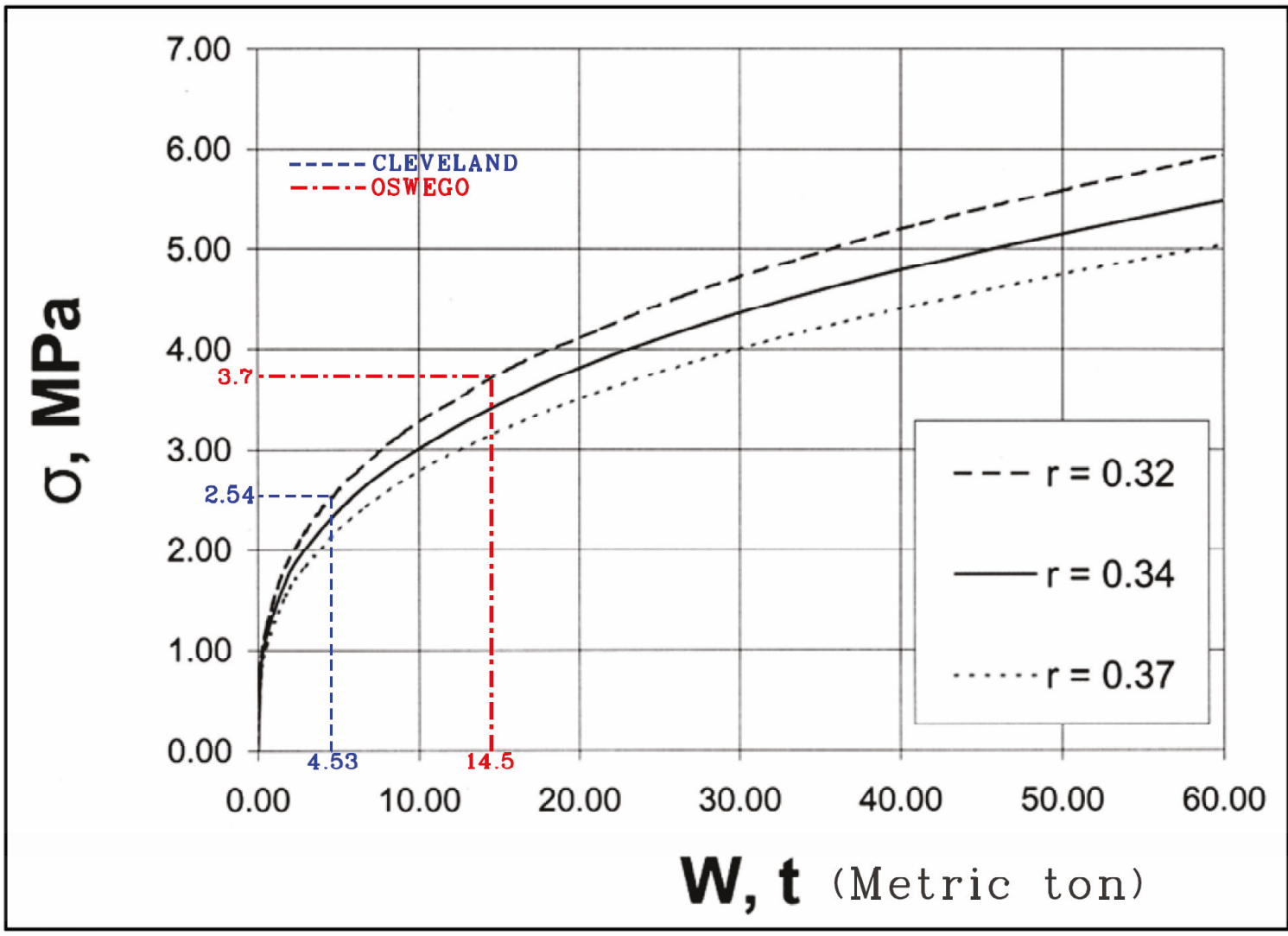


Figure 2-6. 16-ton dolos with steel reinforcement.

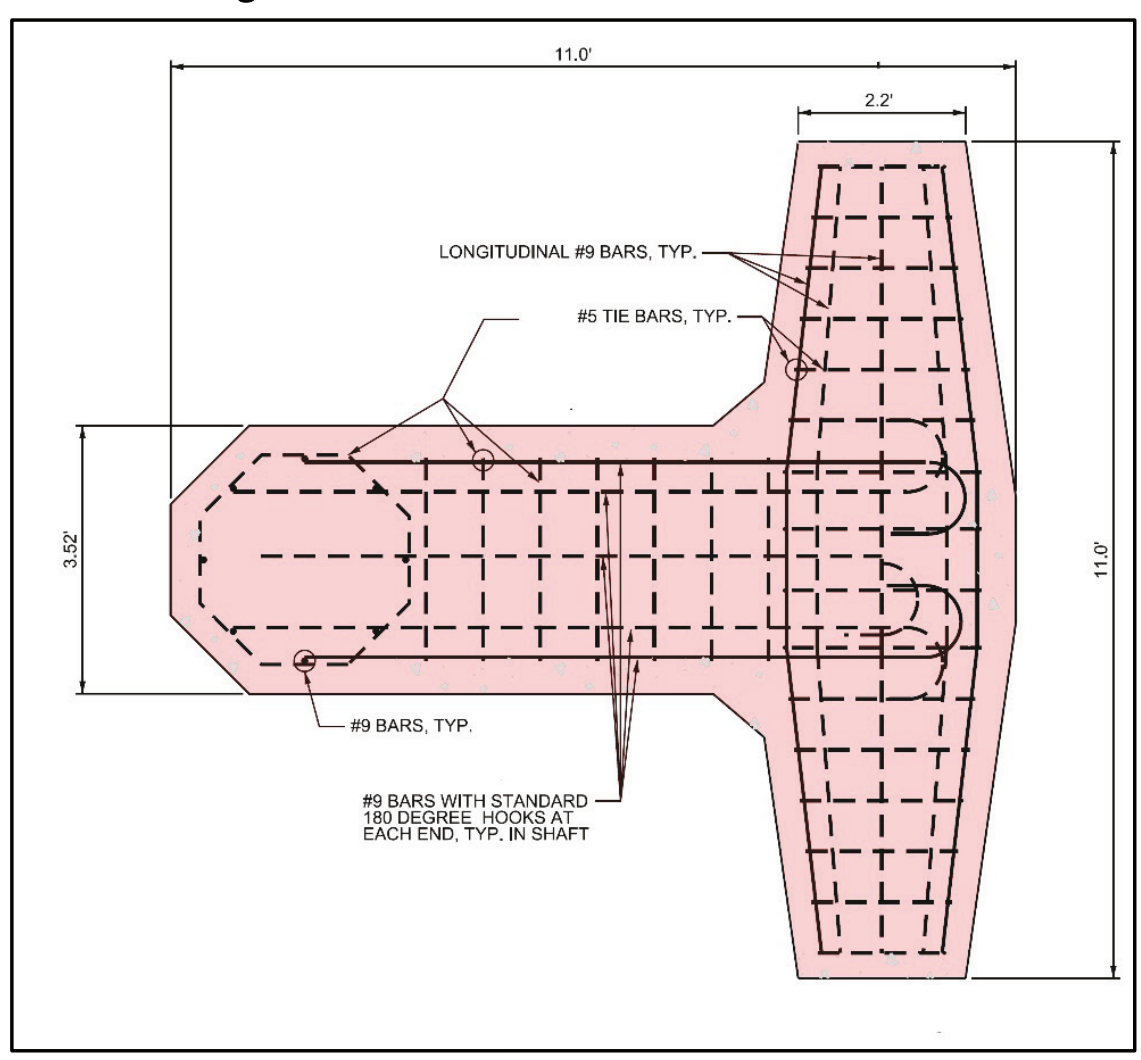

\section{Typical sections and scale models}

The typical repair sections for the dolos overlay for the Cleveland East Breakwater and the Oswego Detached Breakwater are presented in Figure 2-7 and Figure 2-8, respectively.

Figure 2-7. Cleveland East Breakwater typical repair section with 6.5-ton dolosse.

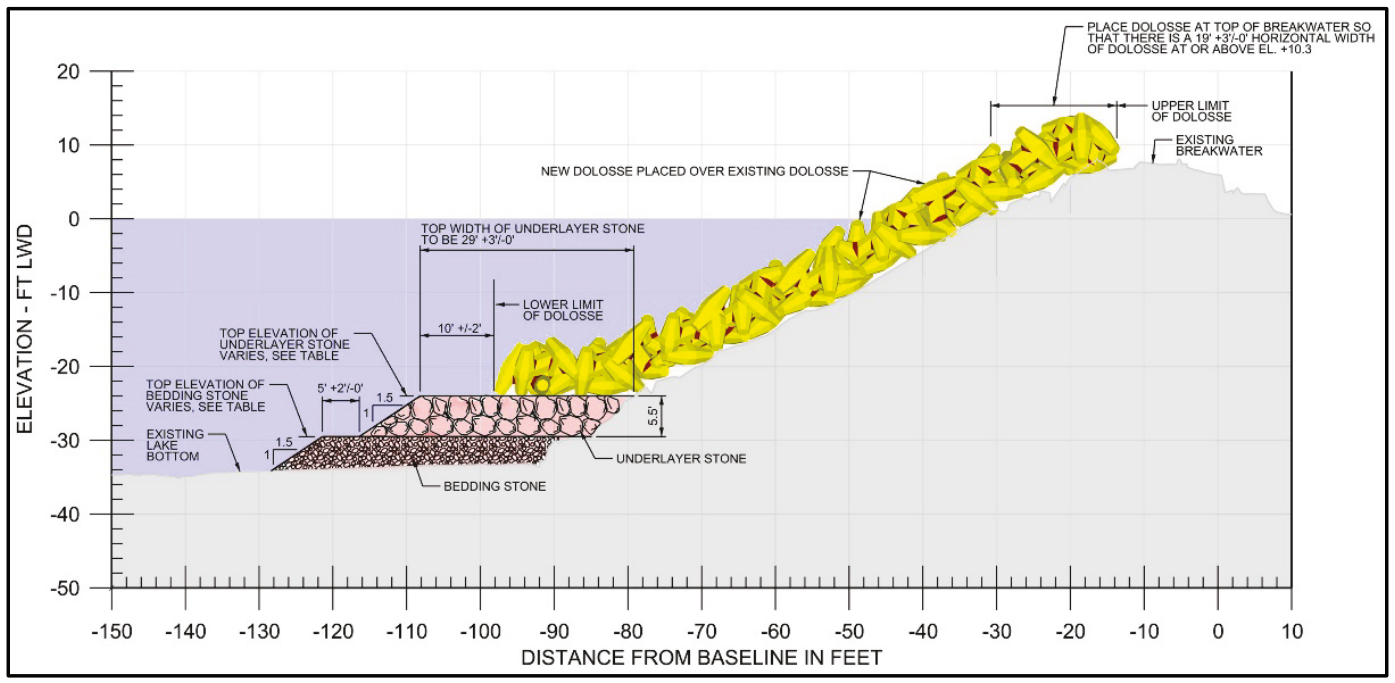


Figure 2-8. Oswego Detached Breakwater typical repair section with 16.0-ton dolosse.

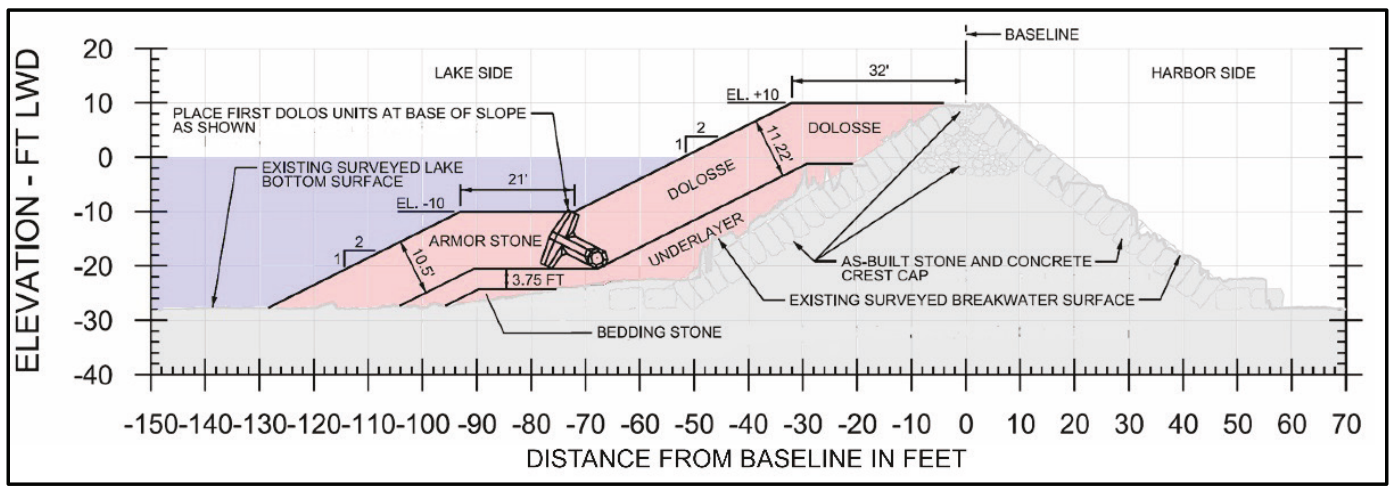

The typical section for the Cleveland dolos overlay was based on the previously constructed dolos overlay. The existing dolosse provided a rough slope for the random placement of the new dolos overlay. This random placement encouraged proper interlocking of the new dolosse. The typical section for the Oswego dolos overlay is an initial placement over a laid-up stone breakwater. The laid-up stone posed as a concern for slope stability. The specific placement of the toe dolosse was to ensure a stable slope, and the proper interlocking of the remaining dolosse would occur.

As the use of dolos units is rare in the Great Lakes, it was deemed important to construct a scale model of the typical section for each project to acquaint the potential bidders with the proposed repair. The models were scaled based upon the number and size of available model dolosse supplied by ERDC. The Cleveland model used a sloping wooden surface at $1 \mathrm{~V}: 2 \mathrm{H}$ to represent the existing dolos surface, was approximately $40 \mathrm{in}$. long $\times 9$ in. high $\times 16$ in. wide, and was scaled at 1 in. $=2.455 \mathrm{ft}$. The Oswego model used an open box design approximately $30 \mathrm{in}$. long $\times 10.5 \mathrm{in}$. high $\times 13$ in. wide, and was constructed using 0.5 in. thick medium density fiberboard with an 8 in. $\times 10$ in. Lexan ${ }^{\mathrm{TM}}$ side viewing window, and was scaled at $1 \mathrm{in} .=$ $4.889 \mathrm{ft}$. Selection of bedding, underlayer, and stone armor material was limited to prepackaged stone material from local home improvement centers, and while hand-sorting of the material was done to most closely scale the material, an approximate stone sizing was achieved. The dolosse models resided at the respective project office, allowing the contractors to deconstruct and reconstruct the model, giving them a better sense of the placement process and visually demonstrated that proper interlocking consists of touching at least two other dolosse. The Cleveland model is shown in Figure 2-9, and the Oswego model in Figure 2-10 and Figure 2-11. 
Figure 2-9. Cleveland East Breakwater scale model.

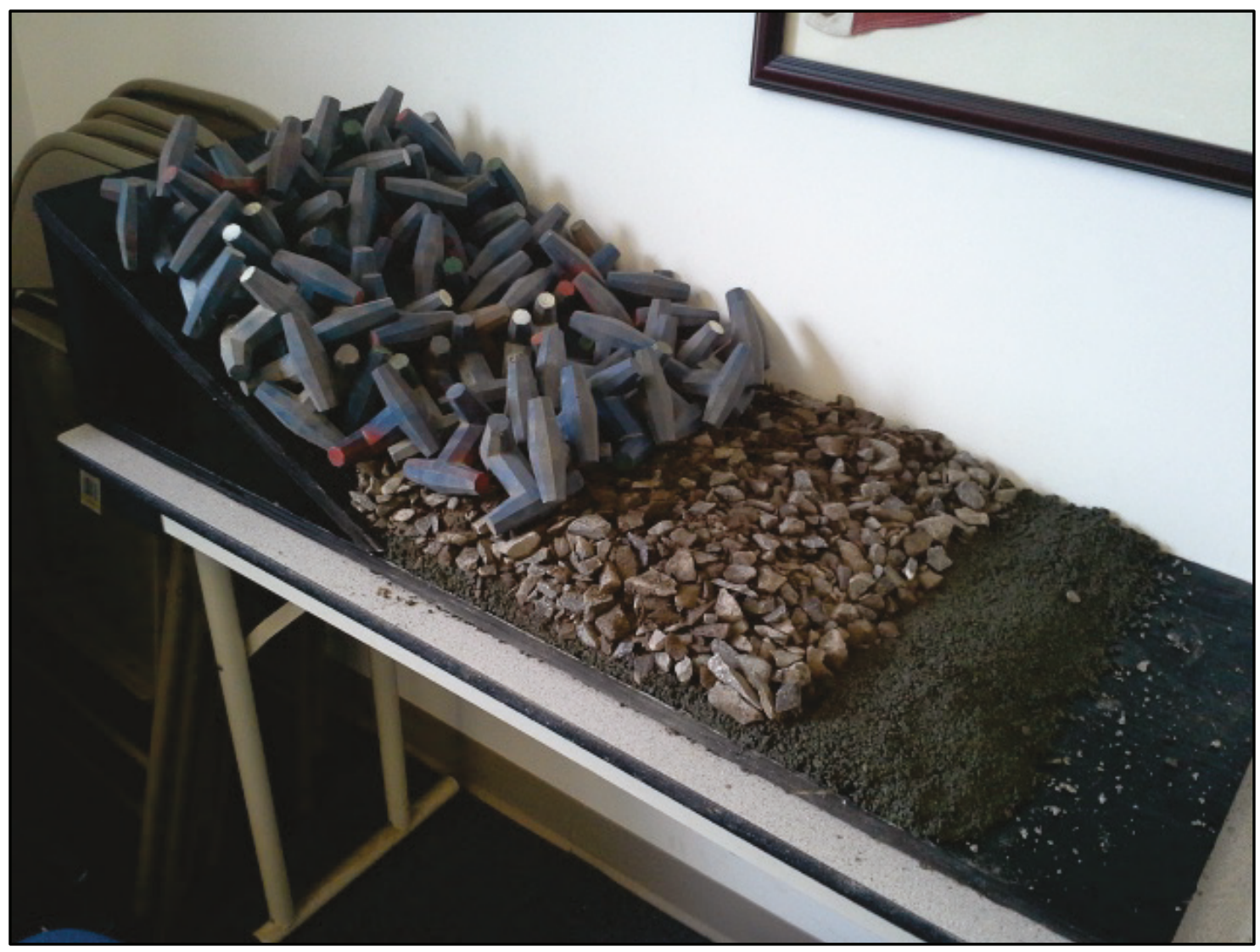

Figure 2-10. Oswego Detached Breakwater scale model with viewing window, side view.

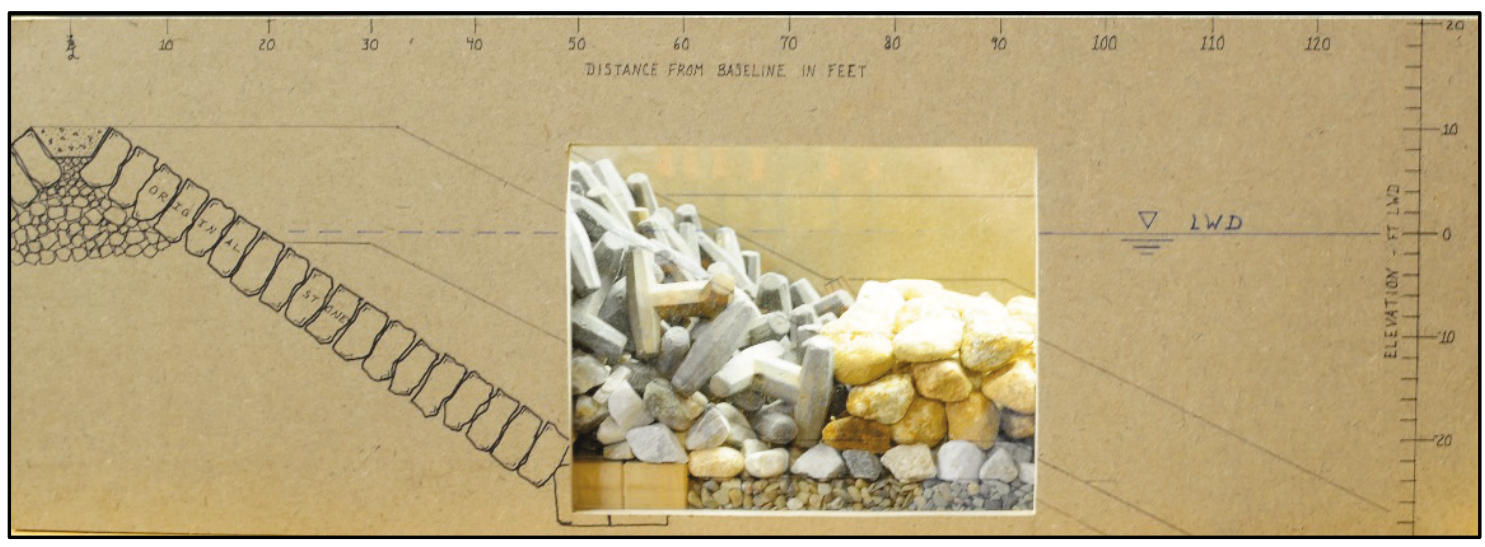


Figure 2-11. Oswego model, front view.

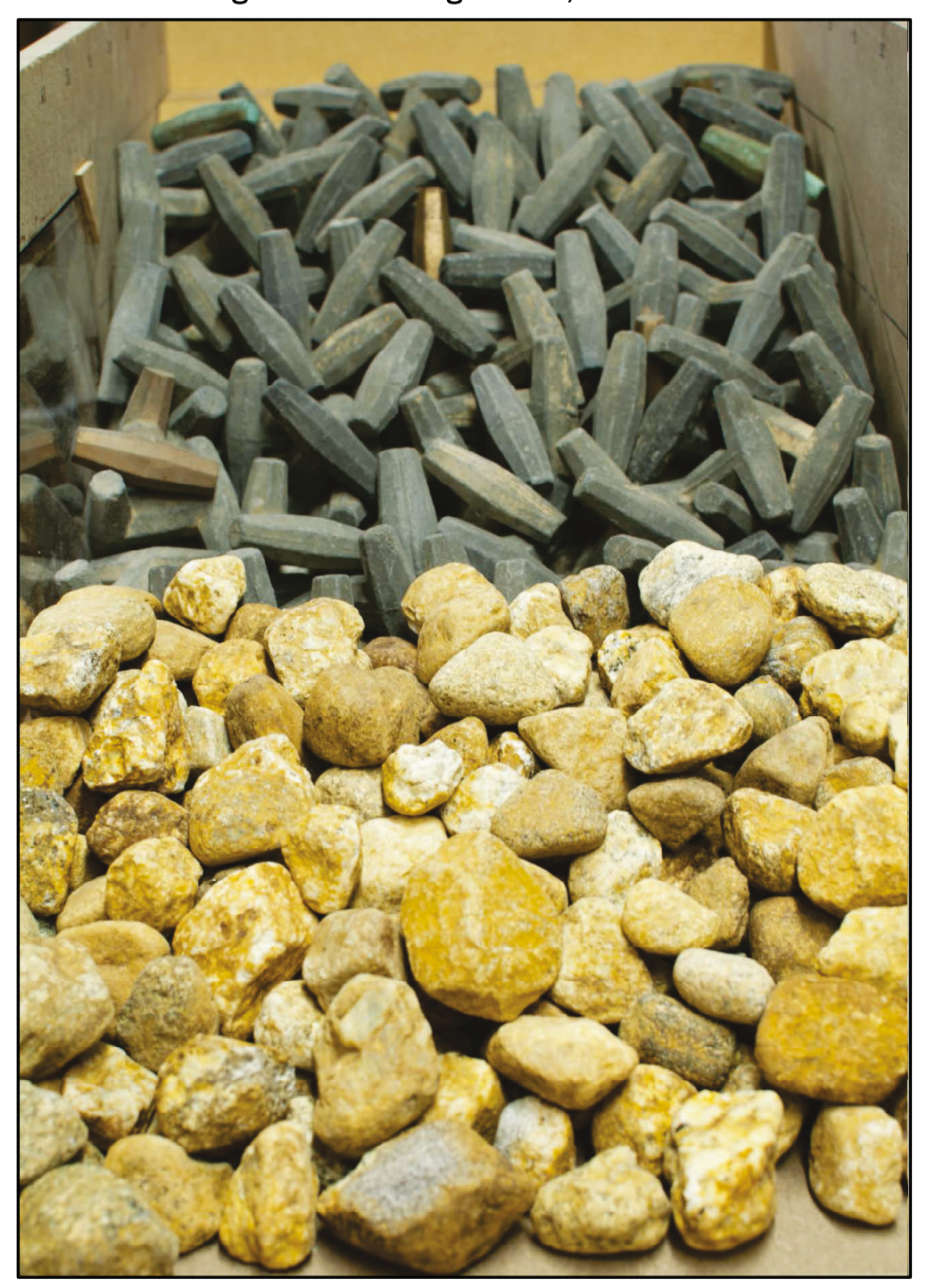




\section{Dolos Construction Techniques}

This section describes the minimum concrete requirements, the creation of the dolos forms, the making and testing of the dolosse, and their final placement (USACE 2014e, 2014f).

\section{Contractor information}

The contractors for the Cleveland East Breakwater 6.5-ton dolos repair were the following:

Dolos Forms and Test Dolos

Lindsay Concrete Products Company

6845 Erie Avenue NW

Canal Fulton, OH 44614

www.lindsayprecast.com

Dolos Production

Allega Anthony Cement Contractor

5585 Canal Rd

Cleveland, $\mathrm{OH} 44125$

www.allega.com

Dolos Placement

Great Lakes Dock and Materials, LLC

1800 Lakeshore Drive

Muskegon, MI 49441

www.greatlakesdock.com

The contractors for the Oswego Detached Breakwater 16-ton dolos repair were the following:

Dolos Forms, Test Dolos, and Dolos Production

Lakelands Concrete Products, Inc.

7520 E Main St

Lima, NY 14485

www.lakelandsconcrete.com 


\section{Dolos Placement}

Kokosing Construction Company

Durocher Marine Division

958 N Huron Street

Cheboygan, MI 49721

www.kokosing.biz

\section{Minimum concrete requirements}

It was required that the precast concrete producers were certified by the Precast/Prestressed Concrete Institute Plant Certification program prior to and during the production of the dolosse. The contractor was to select the mix proportions for normal weight concrete according to the minimum requirements in Table 3-1.

Table 3-1. Cleveland and Oswego minimum concrete requirements.

\begin{tabular}{|c|c|c|c|c|}
\hline Parameter & \multicolumn{2}{|c|}{ Cleveland } & \multicolumn{2}{|c|}{ Oswego } \\
\hline 28-Day Strength, f'c & \multicolumn{2}{|c|}{$5,000 \mathrm{lb} / \mathrm{in}^{2}{ }^{2}$} & \multicolumn{2}{|c|}{$5,000 \mathrm{lb} / \mathrm{in}^{2}{ }^{2}$} \\
\hline $\begin{array}{l}\text { 28-Day Flexural Tensile } \\
\text { Strength }\end{array}$ & \multicolumn{2}{|c|}{500 lb/in.2 } & \multicolumn{2}{|c|}{ Not specified, since steel reinforced } \\
\hline Weight & \multicolumn{2}{|c|}{$140 \mathrm{lb} / \mathrm{ft}^{3}$} & \multicolumn{2}{|c|}{$145 \mathrm{lb} / \mathrm{ft}^{3}$} \\
\hline Water-to-Cement Ratio & \multicolumn{2}{|c|}{0.45 or less } & \multicolumn{2}{|c|}{0.45 or less } \\
\hline \multirow{6}{*}{ Air Content } & $\begin{array}{l}\text { Nominal Maximum } \\
\text { Aggregate Size, in. }\end{array}$ & Air Content, \% & $\begin{array}{l}\text { Nominal Maximum } \\
\text { Aggregate Size, in. }\end{array}$ & Air Content, \% \\
\hline & 0.38 & 6.0 to 9.0 & 0.38 & 6.0 to 9.0 \\
\hline & 0.50 & 5.5 to 8.5 & 0.50 & 5.5 to 8.5 \\
\hline & 0.75 & 4.5 to 7.5 & 0.75 & 4.5 to 7.5 \\
\hline & 1.00 & 4.5 to 7.5 & 1.00 & 4.5 to 7.5 \\
\hline & 1.50 & 4.5 to 7.0 & 1.50 & 4.5 to 7.0 \\
\hline
\end{tabular}




\section{Dolos forms}

As in any casting operation, the forms used must be robust (steel sufficiently thick to limit flexing) and reusable, must ensure complete filling with no air pockets or segregation of the concrete, and must allow easy extraction of the dolosse. This was especially true for the Cleveland project wherein a very large number of dolosse were required. To confirm the creation of a quality dolos, each contractor was required to produce a sample dolos. These dolosse were subjected to visual inspection, strength testing, and destructive testing.

The creation of the 6.5-ton dolos forms are presented in Figure 3-1, Figure 3-2, and Figure 3-3.

Figure 3-1. Constructing Cleveland 6.5-ton dolos forms.

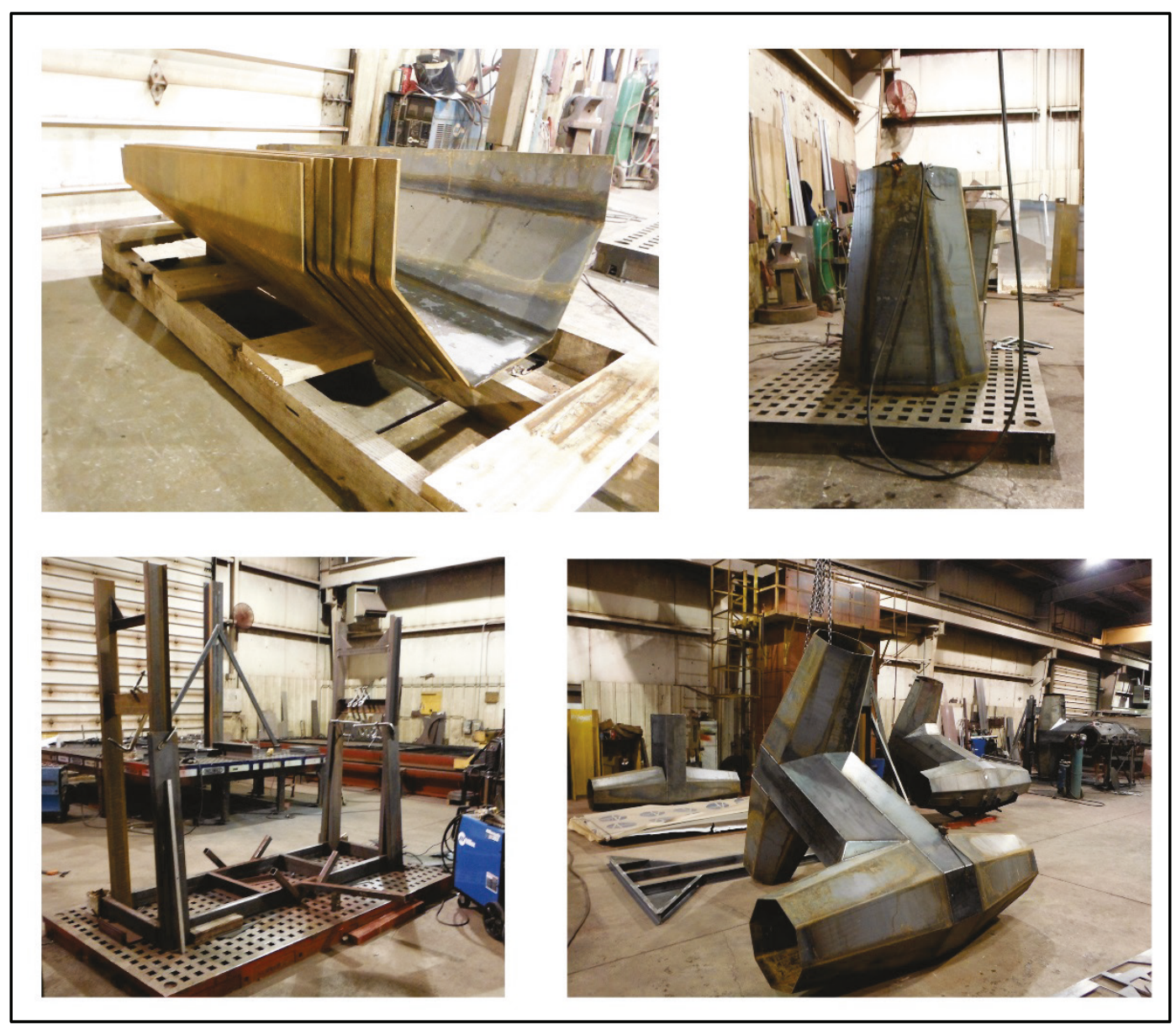


Figure 3-2. Constructing Cleveland 6.5-ton dolos forms.

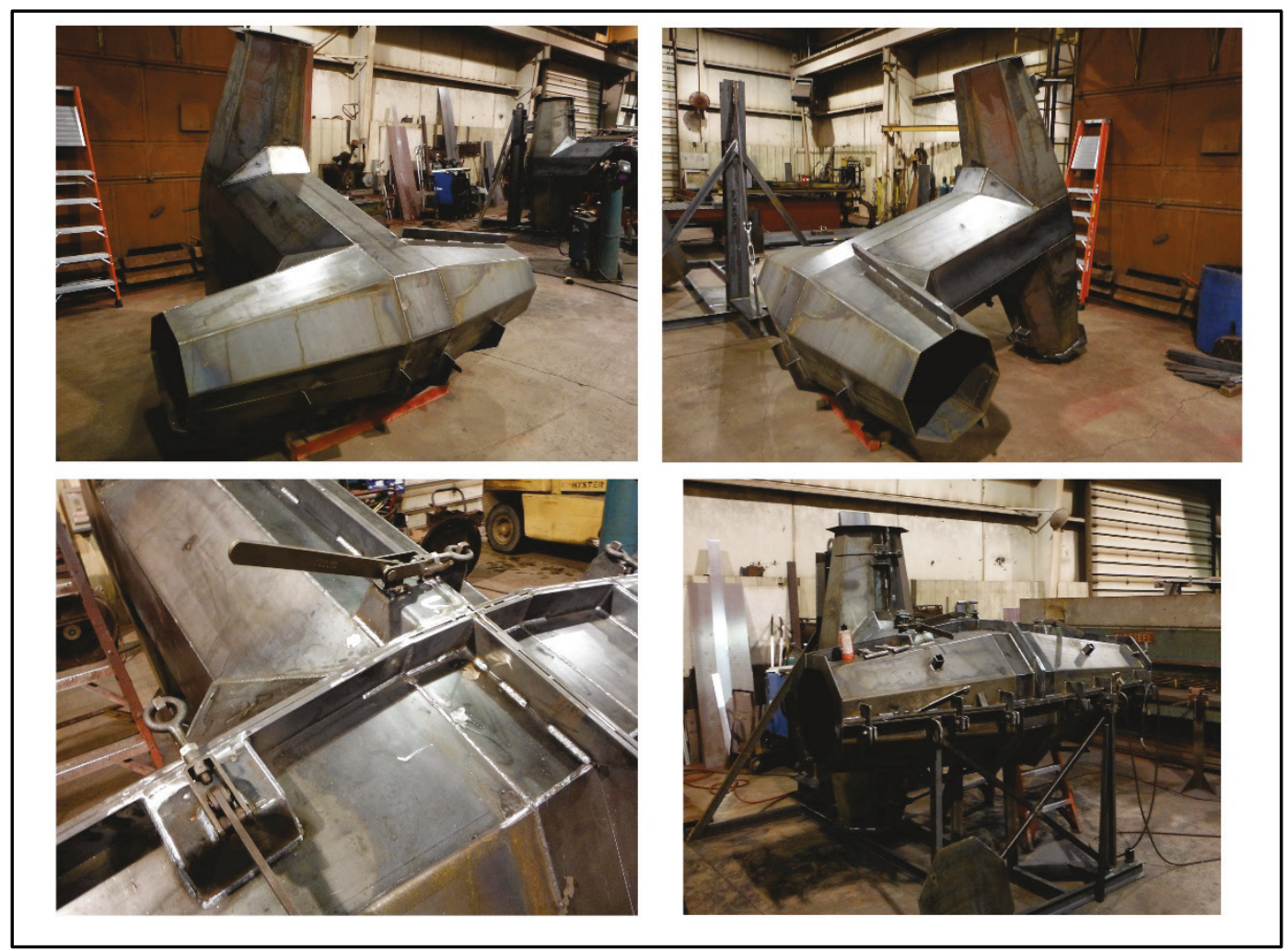

Figure 3-3. Completed Cleveland 6.5-ton dolos forms.

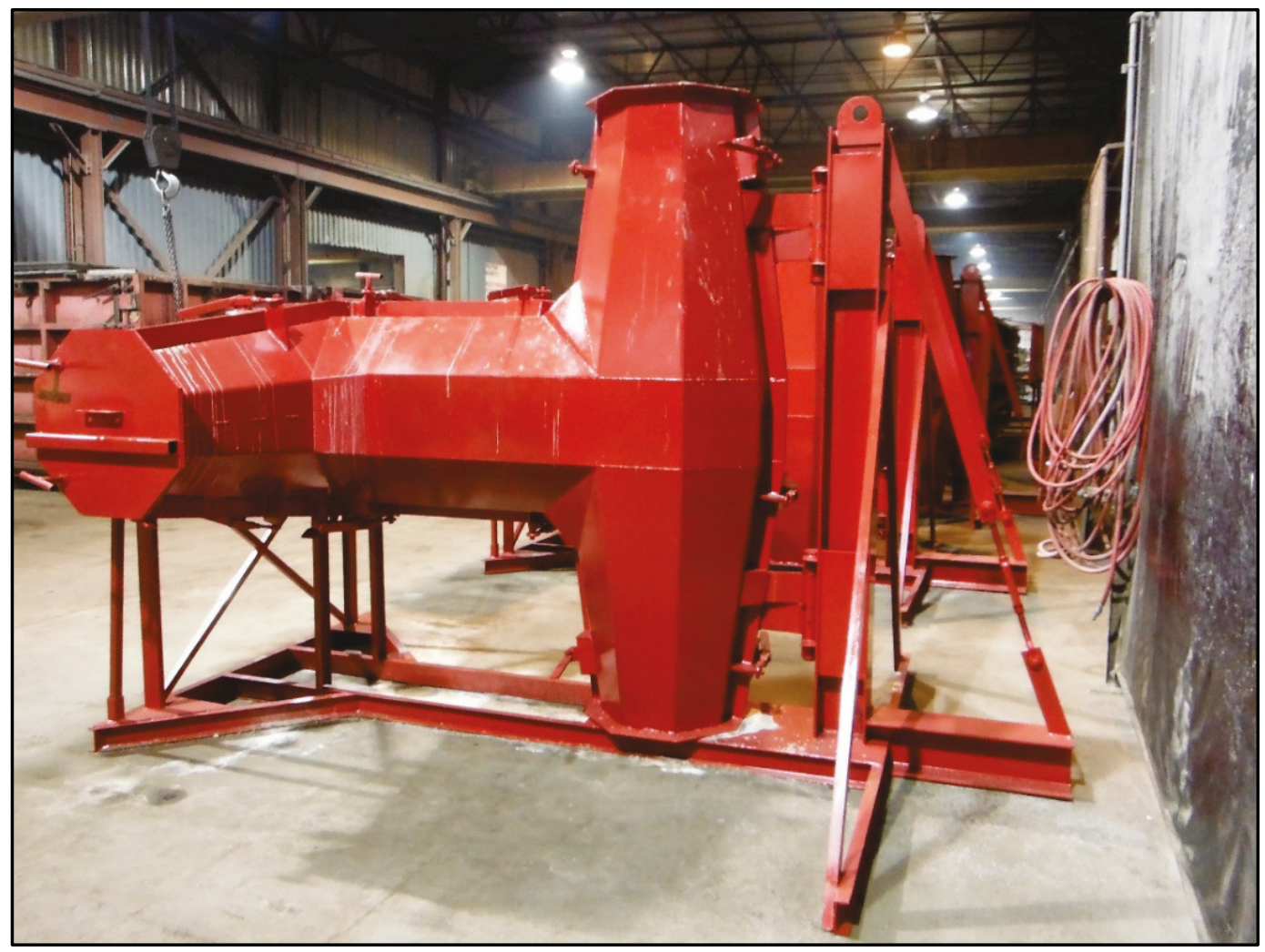


Figure 3-4 and Figure 3-5 present images of the forms for the Oswego 16-ton dolos. Note the presence of the external ribs for additional strength. Dolos steel reinforcement is seen in the form in the latter image.

Figure 3-4. Oswego Detached Breakwater 16-ton dolos form.

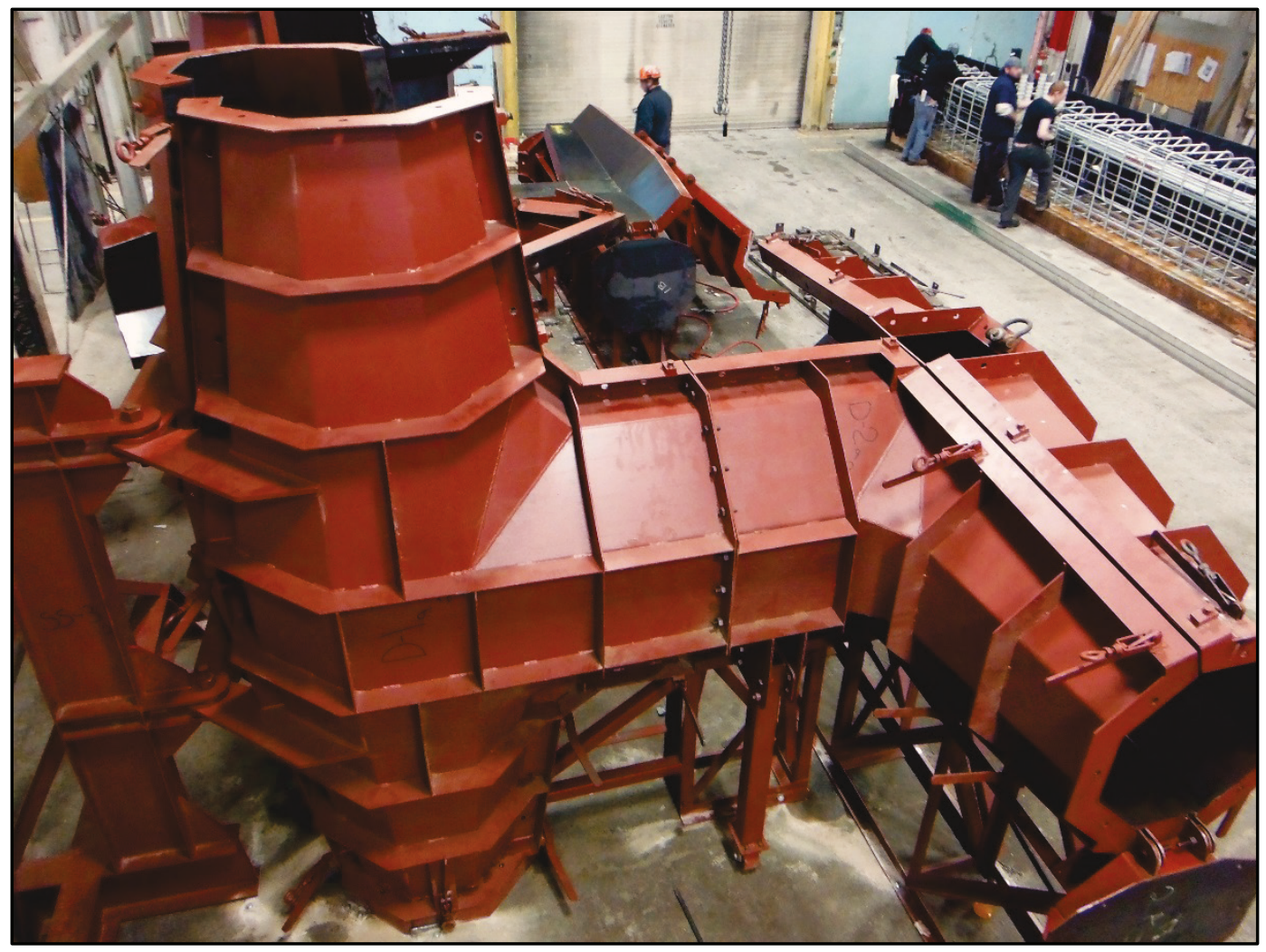


Figure 3-5. Oswego Detached Breakwater 16-ton dolos form.

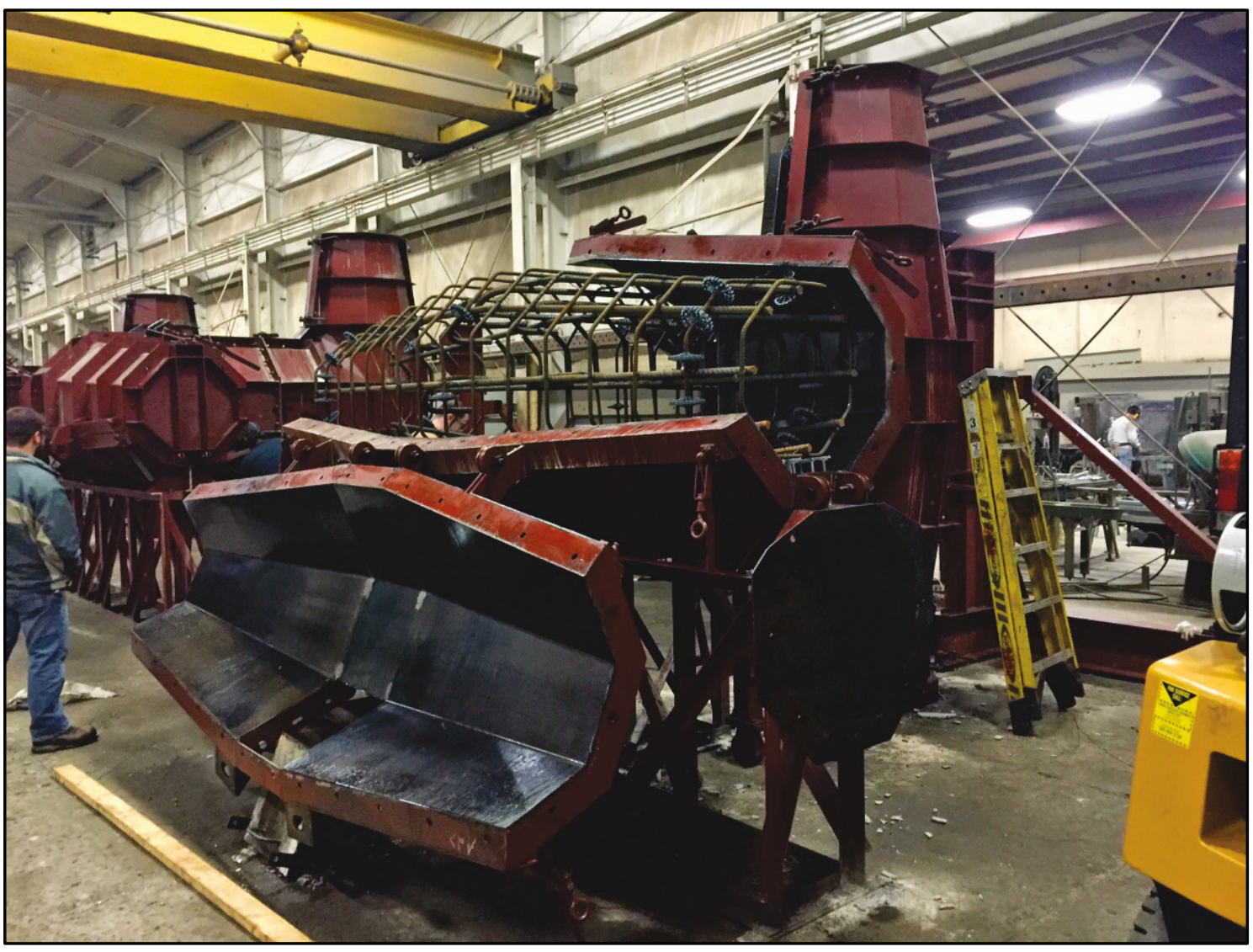

Casting the dolos was accomplished by placing the concrete through the top of the form (vertical fluke end). Once cured, the dolos was removed by loosening the bolts and latches, opening the top horizontal fluke form flaps and the side wings, placing a strap around the shaft center, and lifting. This sequence, captured from videos ${ }^{1}$ or still photos, is shown in Figure 3-6 through Figure 3-11. Note that yard handling of the Oswego 16-ton was accomplished by using a spreader beam of the straddle crane that attached to the precast eyes in the dolos (Figure 3-12).

\footnotetext{
1 Faces of individuals are intentionally blurred to mask their identities.
} 
Figure 3-6. Placing concrete for Cleveland 6.5-ton dolos.

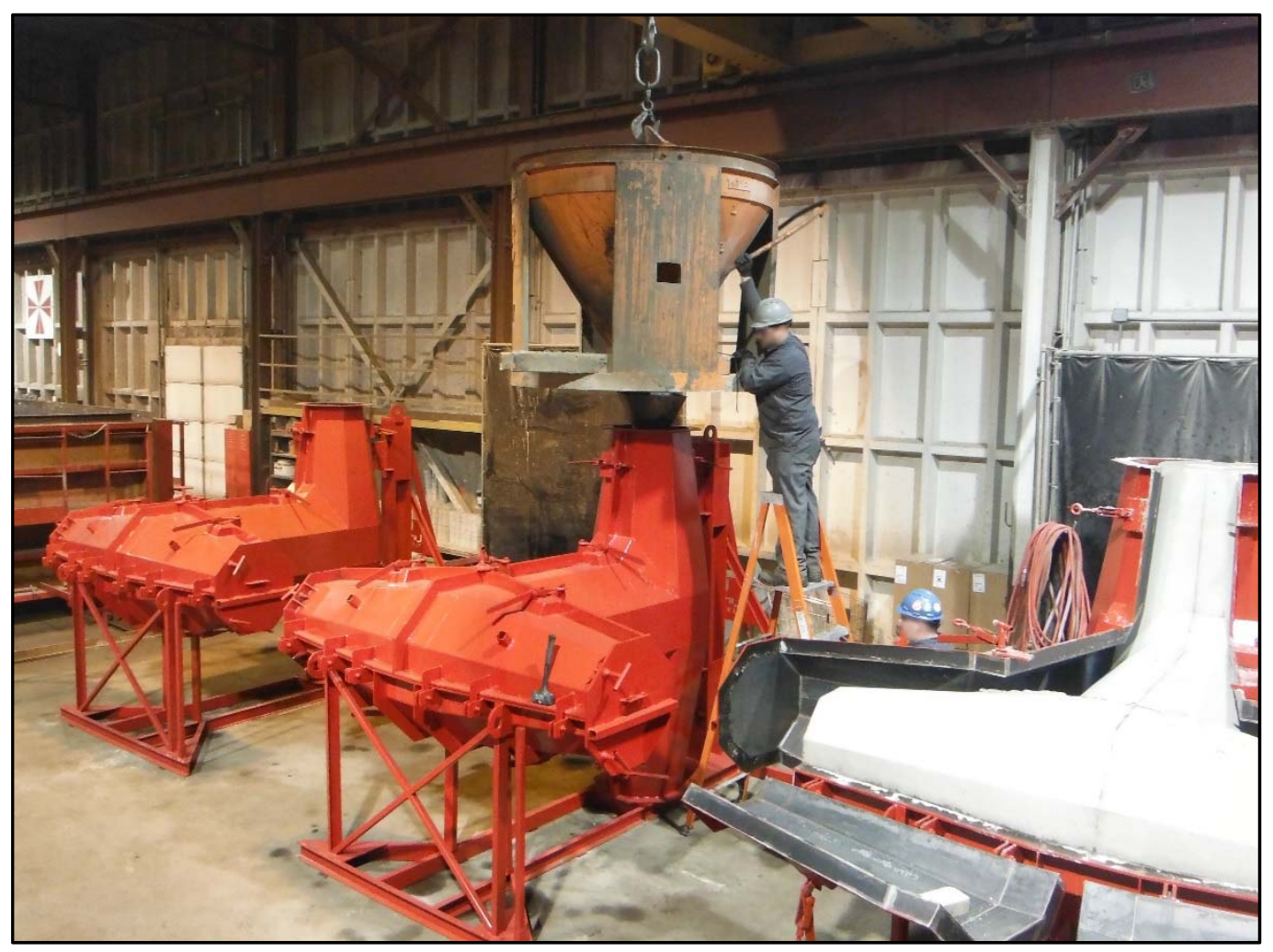

Figure 3-7. Loosening bolts and opening latches on Cleveland 6.5-ton dolos form.

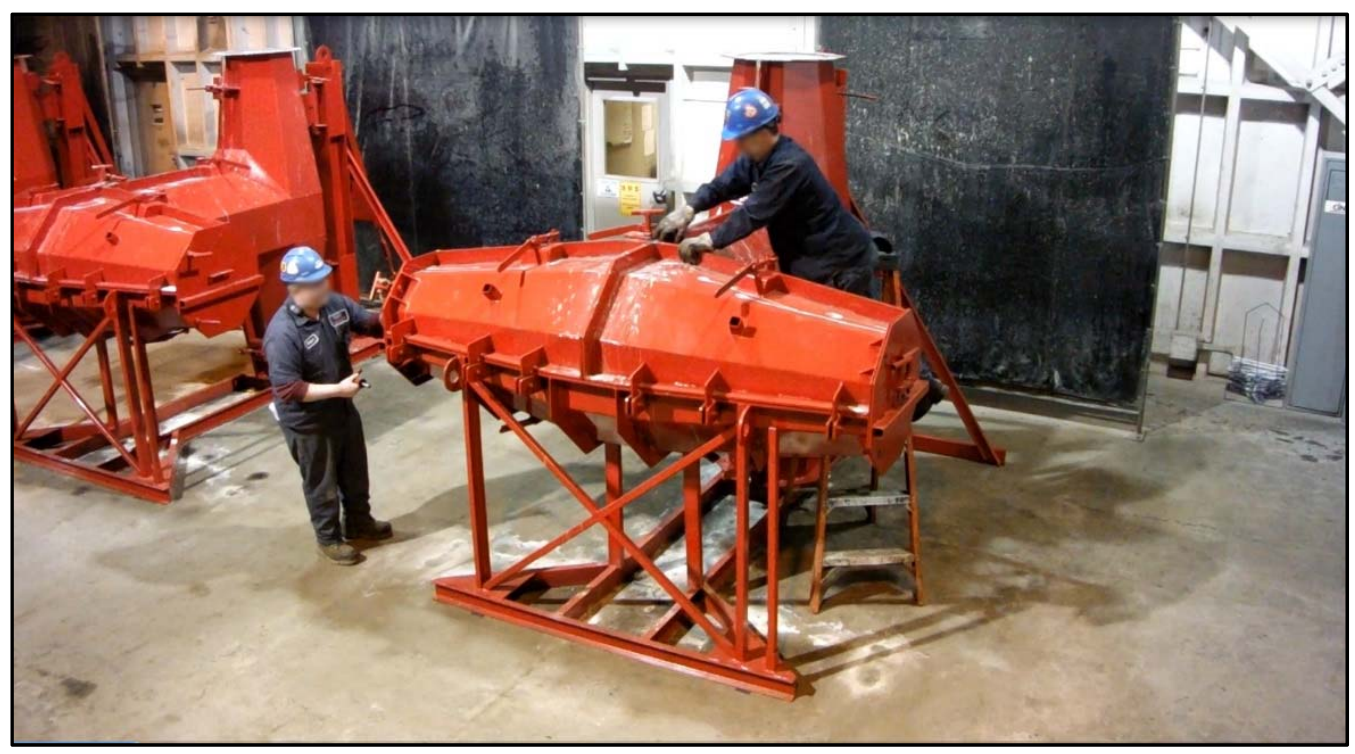


Figure 3-8. Opening Cleveland 6.5-ton dolos form fluke flaps.

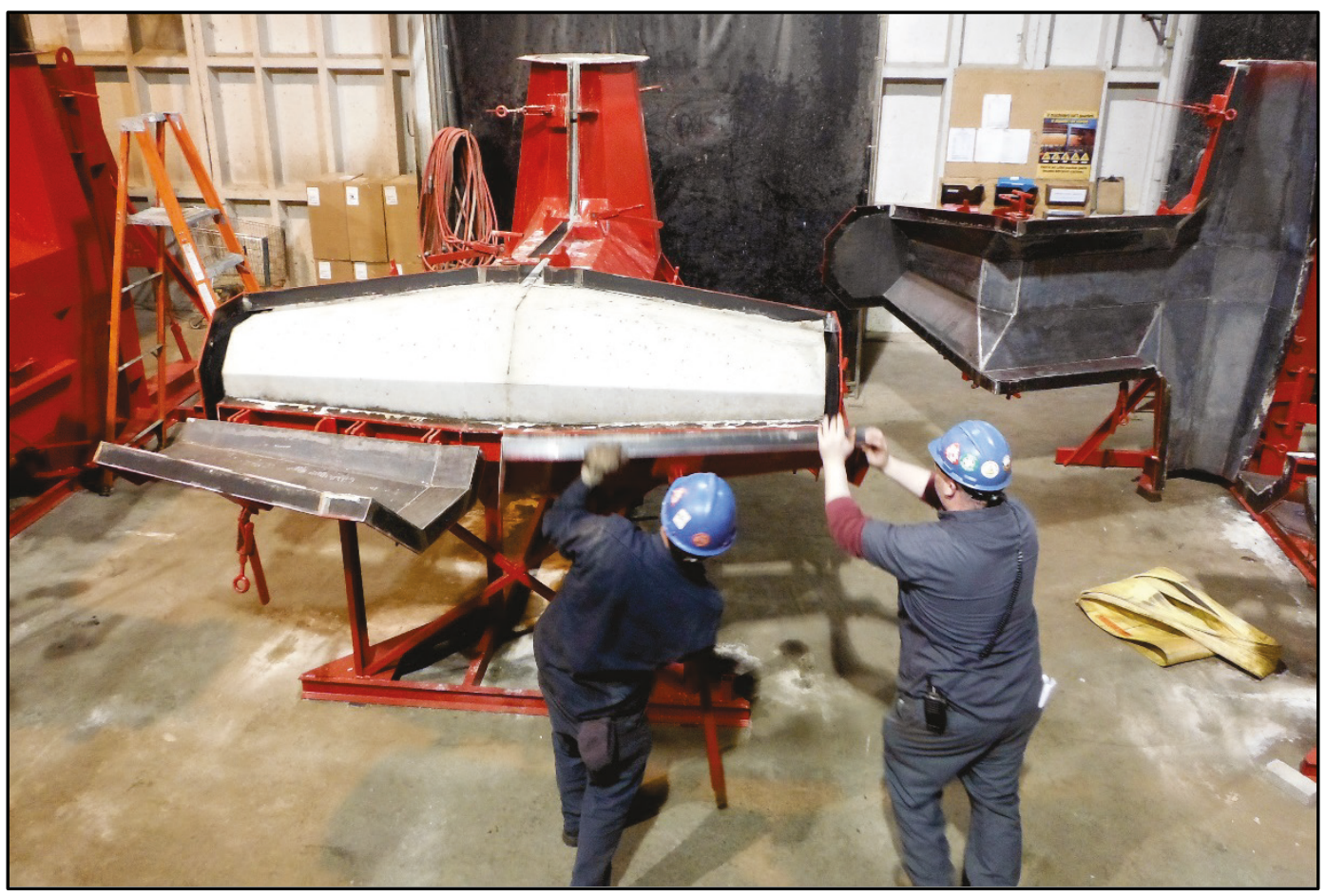

Figure 3-9. Opening Cleveland 6.5-ton dolos form side wings.

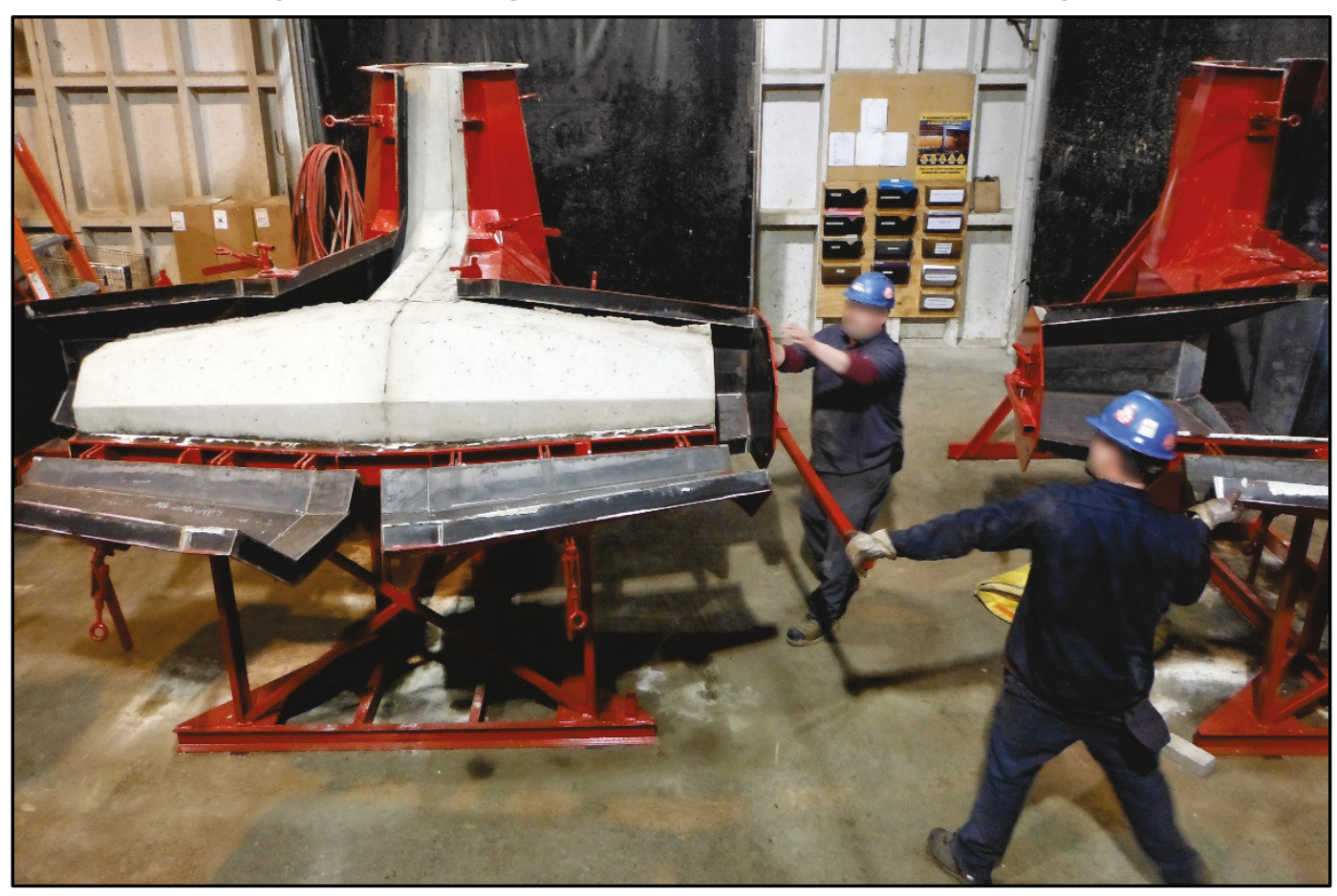


Figure 3-10. Lifting Cleveland 6.5-ton dolos out of form.

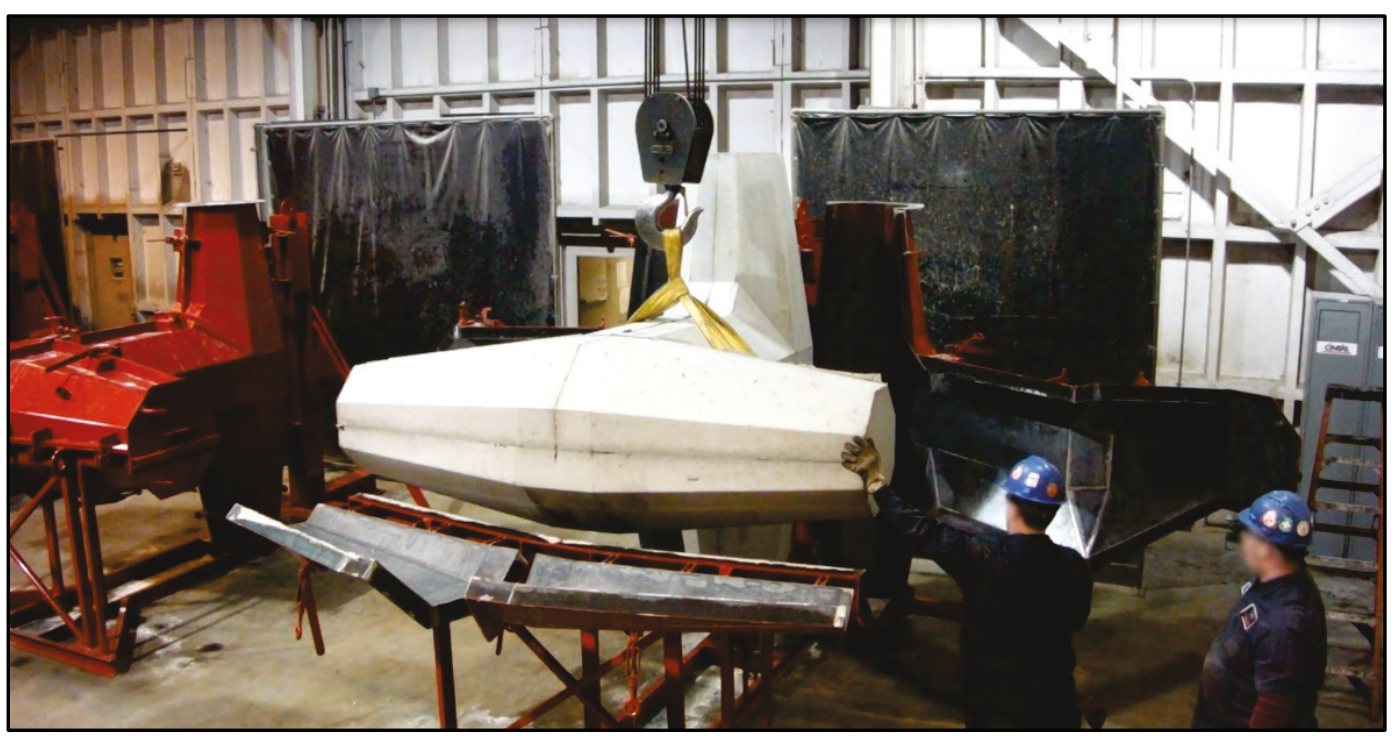

Figure 3-11. Cleveland 6.5-ton dolos empty open form.

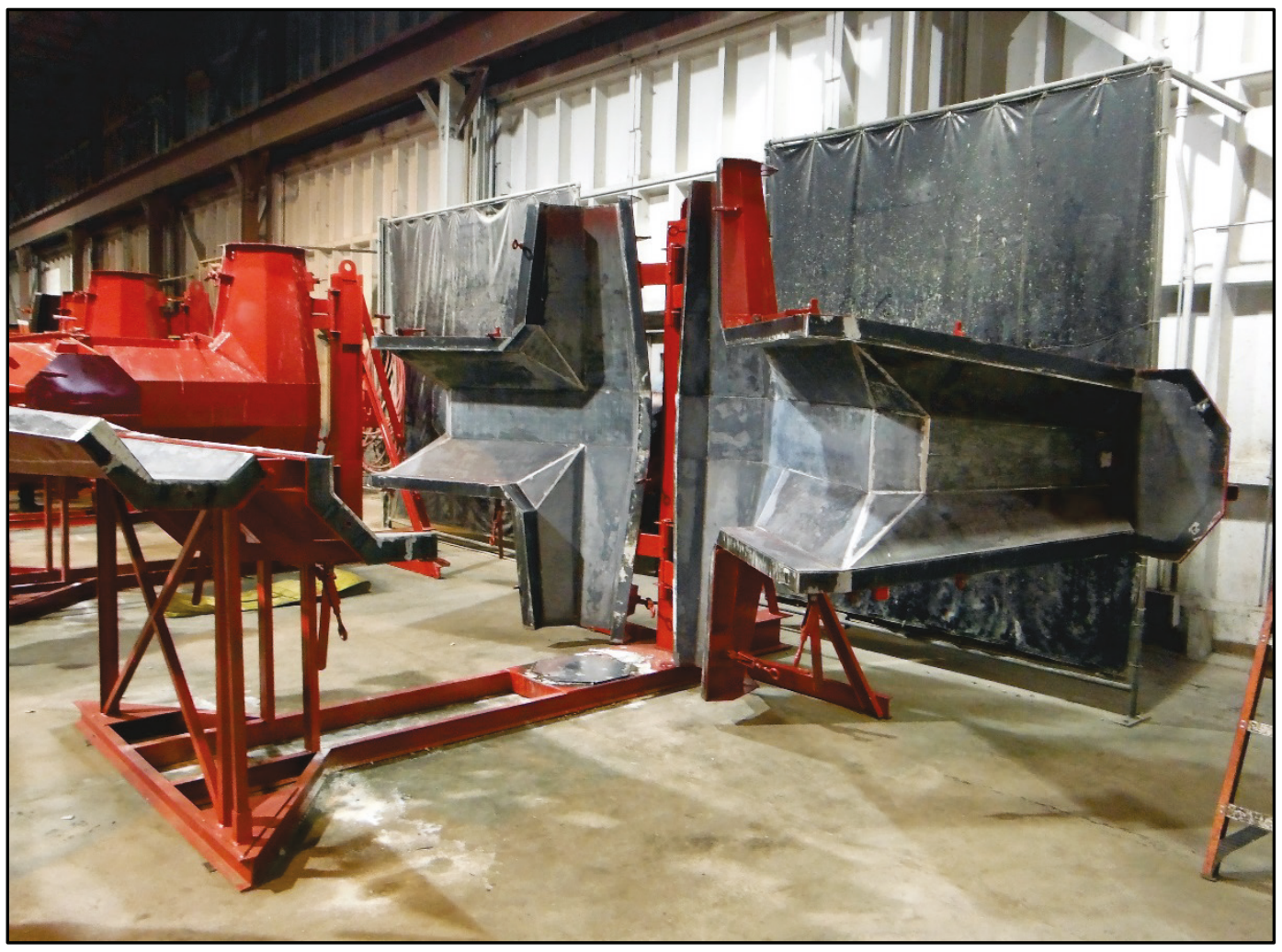


Figure 3-12. Lift method when moving Oswego 16-ton dolos.

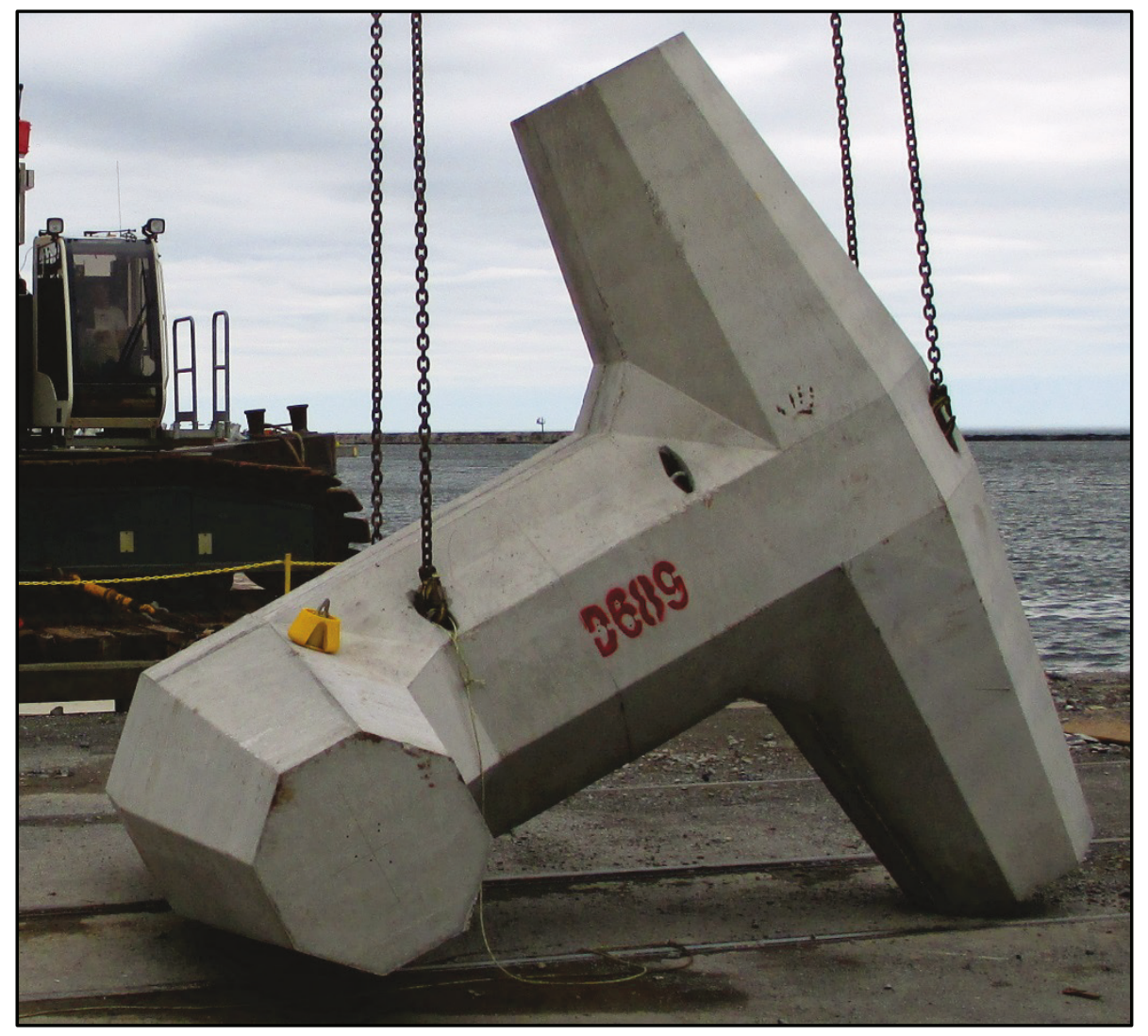

After having made the sample dolos, the contractor cut the dolos (in the presence of a government representative) to check for voids and other imperfections in the following manner:

- Flukes from both ends were cut from the dolos at the shank.

- One fluke from each end was cut into three equal pieces crosssectionally.

- The remaining flukes were cut in half, longitudinally.

- The shank was cut in half, cross-sectionally.

- One half was cut into three equal parts, cross-sectionally.

- The other half was cut in half, longitudinally.

Figure 3-13 and Figure 3-14 show a Cleveland 6.5-ton dolos being cut with a circular saw and an Oswego 16-ton dolos being cut with a wire saw, respectively. Photo inserts show a cut sample. For each project, the tests demonstrated that there was no segregation of aggregates, there were no large voids or air pockets within the mass, and for the 16-ton dolosse there was good concrete bond to the rebar. 
Figure 3-13. Cutting Cleveland 6.5-ton dolos and cut sample.

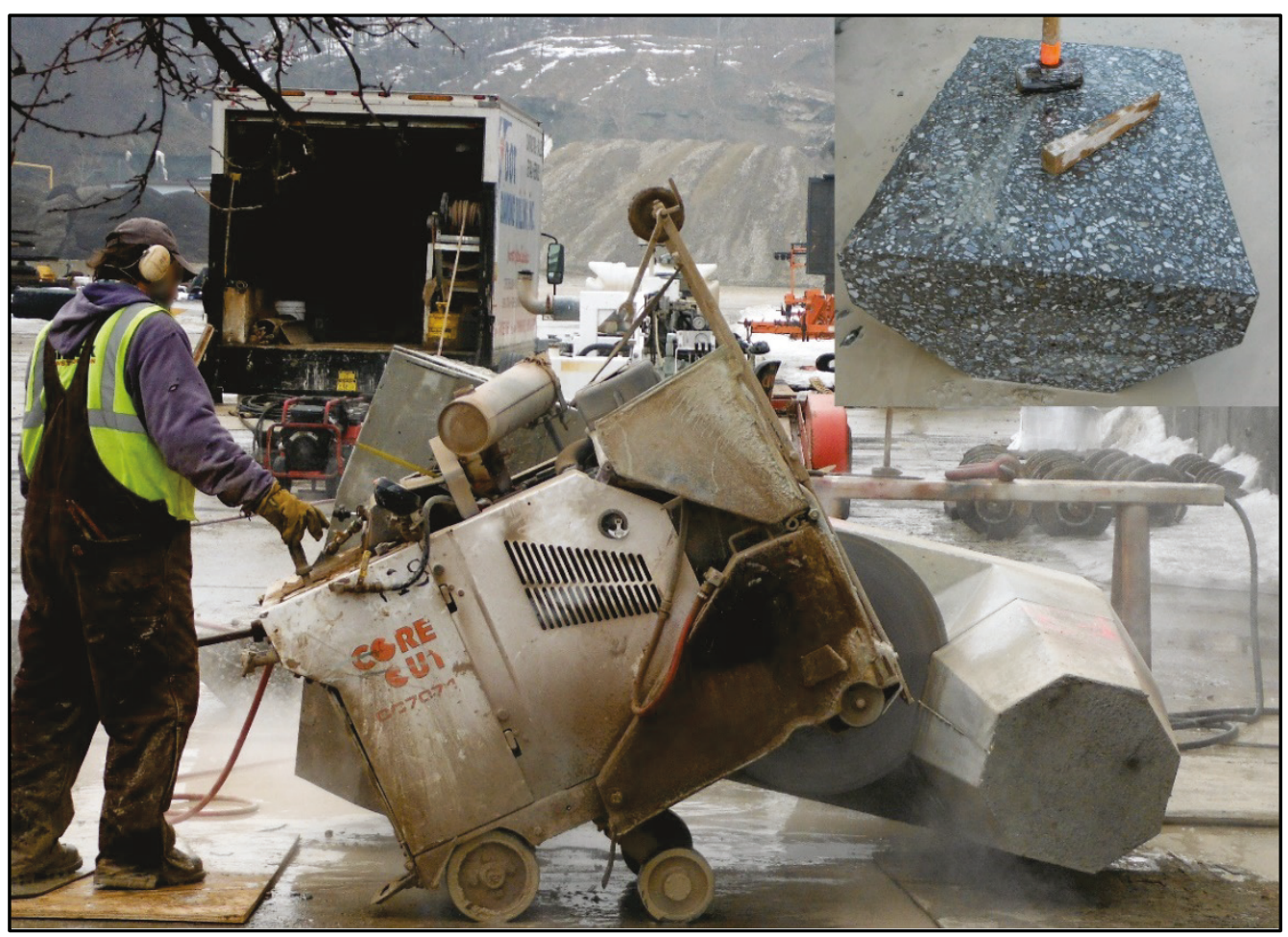

Figure 3-14. Cutting Oswego 16-ton dolos and cut sample.

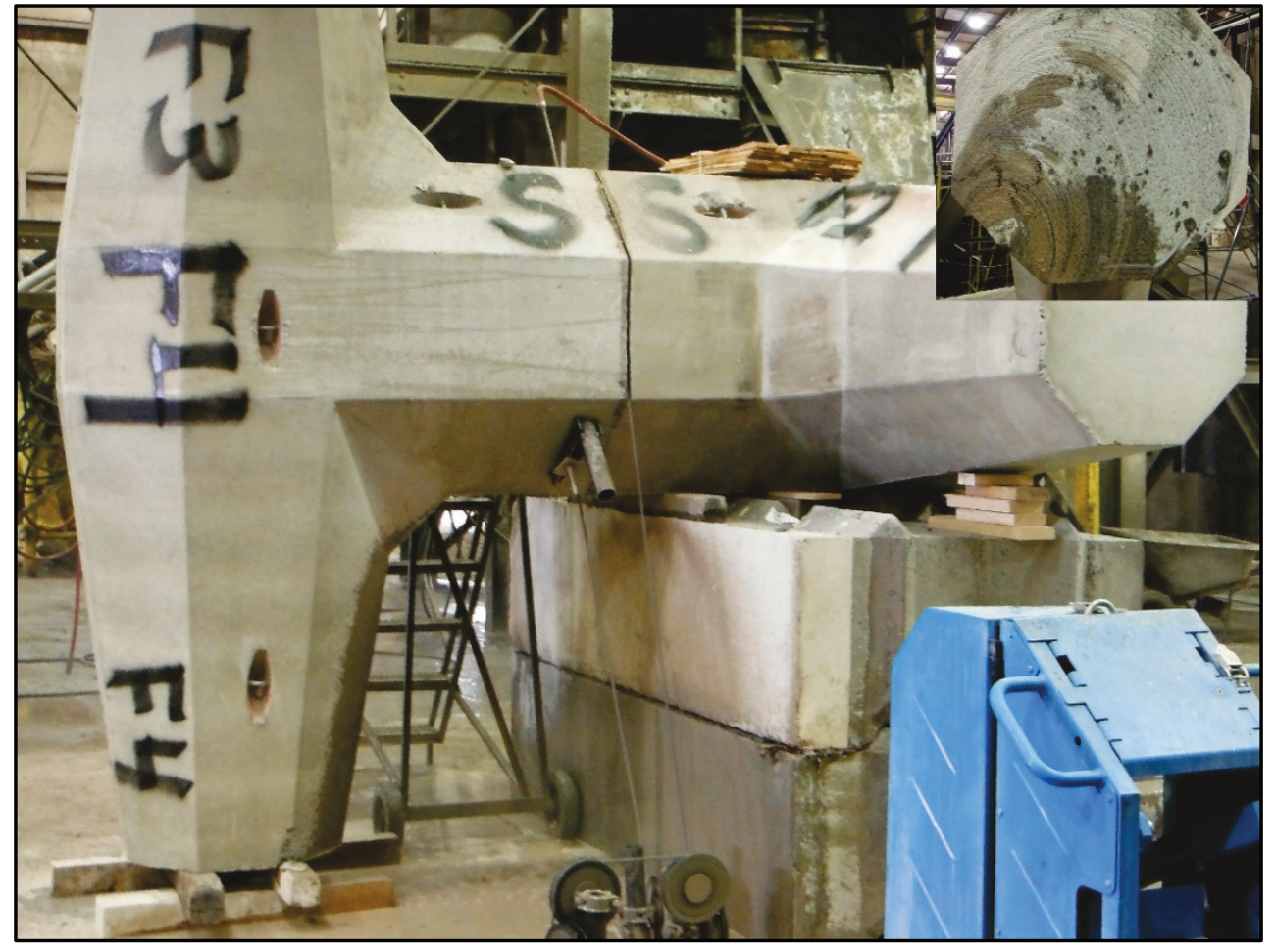




\section{Dolos production}

\section{Production rate}

The Cleveland East Breakwater repair required the placement of 18,259 6.5-ton dolosse. To produce such a large number within the 2-year construction window, Allega Concrete used 54 forms, and the dolosse were made outside in the Allegra Concrete yard. Concrete was mixed in 10.5 cubic yards (yd3) batches, filling approximately three forms per batch. The mix design was modified for the units to be safely removed from the forms each half day (12 hr). The yard space used to make and store the dolosse until they could be shipped was approximately 5.5 acres (Figure 3-15).

Figure 3-15. Ground view of Allega Concrete forms and curing dolosse, June 2015.

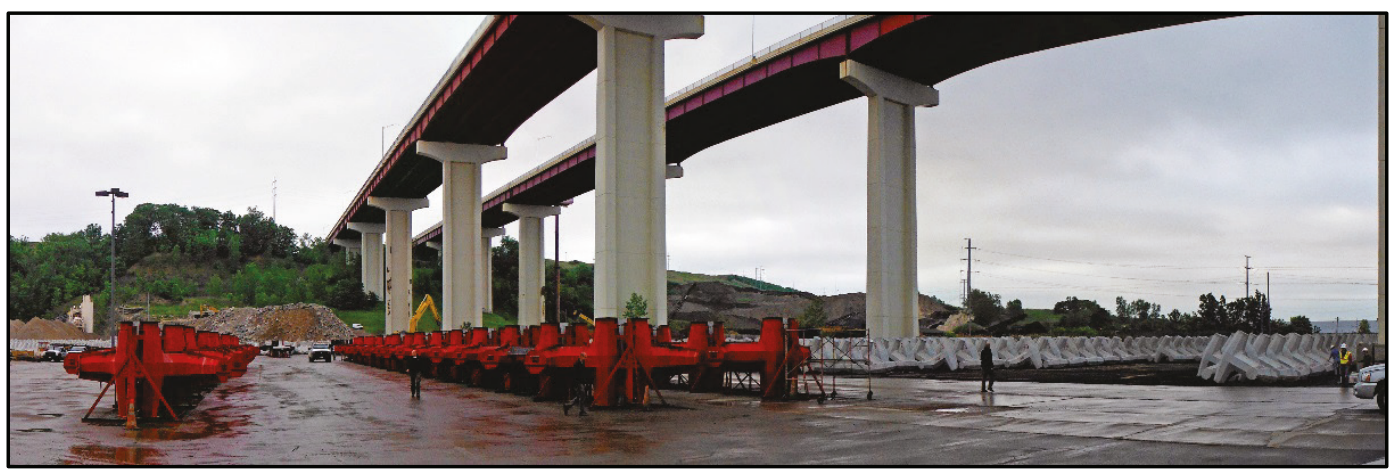

The Oswego Detached Breakwater required 973 16-ton dolosse. Lakelands Concrete chose to build the steel reinforcement cages and cast the dolosse inside the its plant using eight forms. The concrete mix was designed to allow the dolosse to be removed from the forms each day ( $24 \mathrm{hr}$ ), with the outside designated dolos storage area occupying approximately 2.5 acres (Figure 3-16). The contractor requested a slight change to the dolos shape by chamfering the inner facet of the vertical fluke (orientation when casting) to aid in the removal from the form, which added a slight addition of material (Figure 3-17). 
Figure 3-16. Lakeland storage yard for Oswego 16-ton dolosse, February 2015.

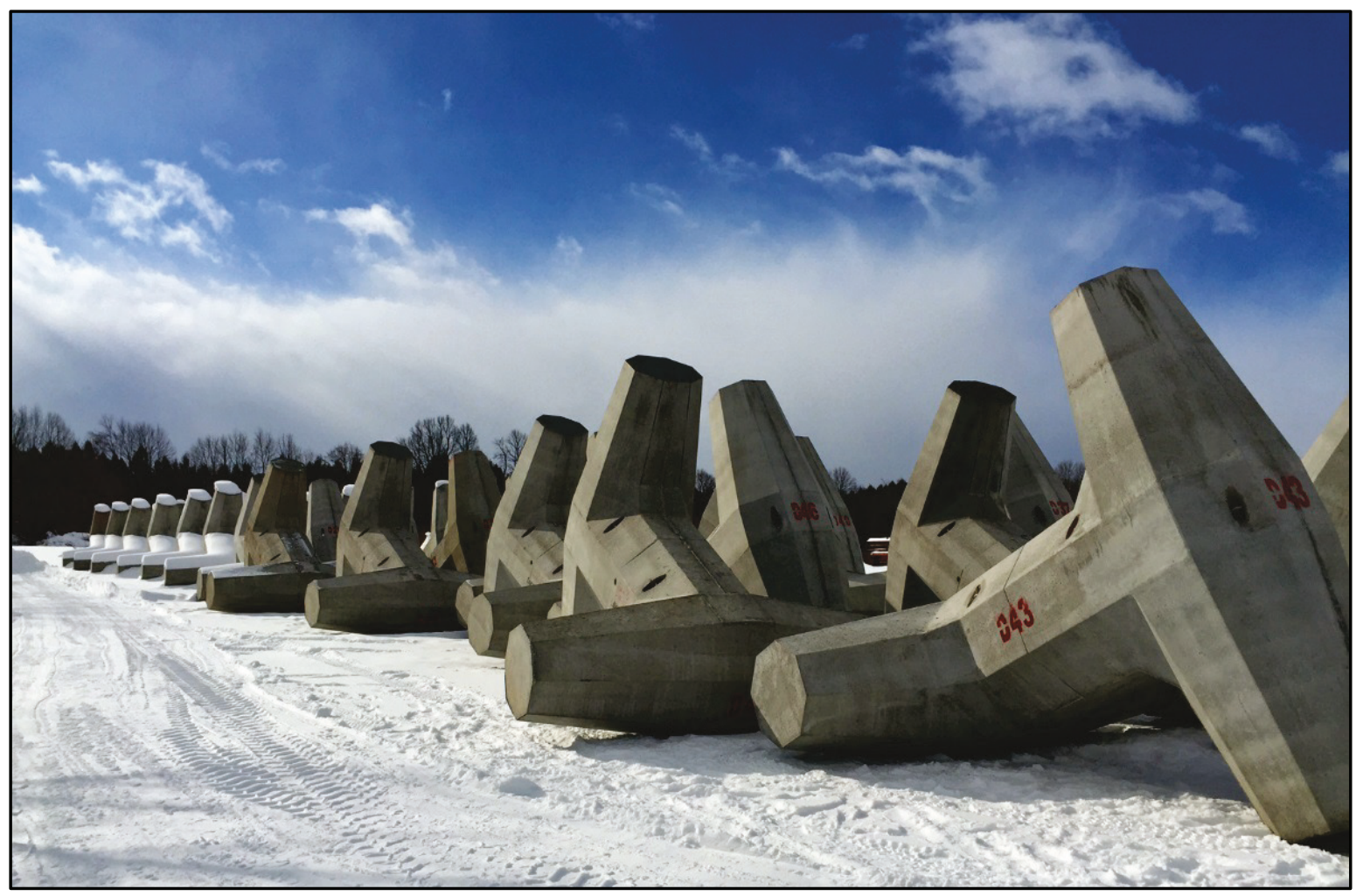

Figure 3-17. Minor modification to Oswego 16-ton dolos shape.

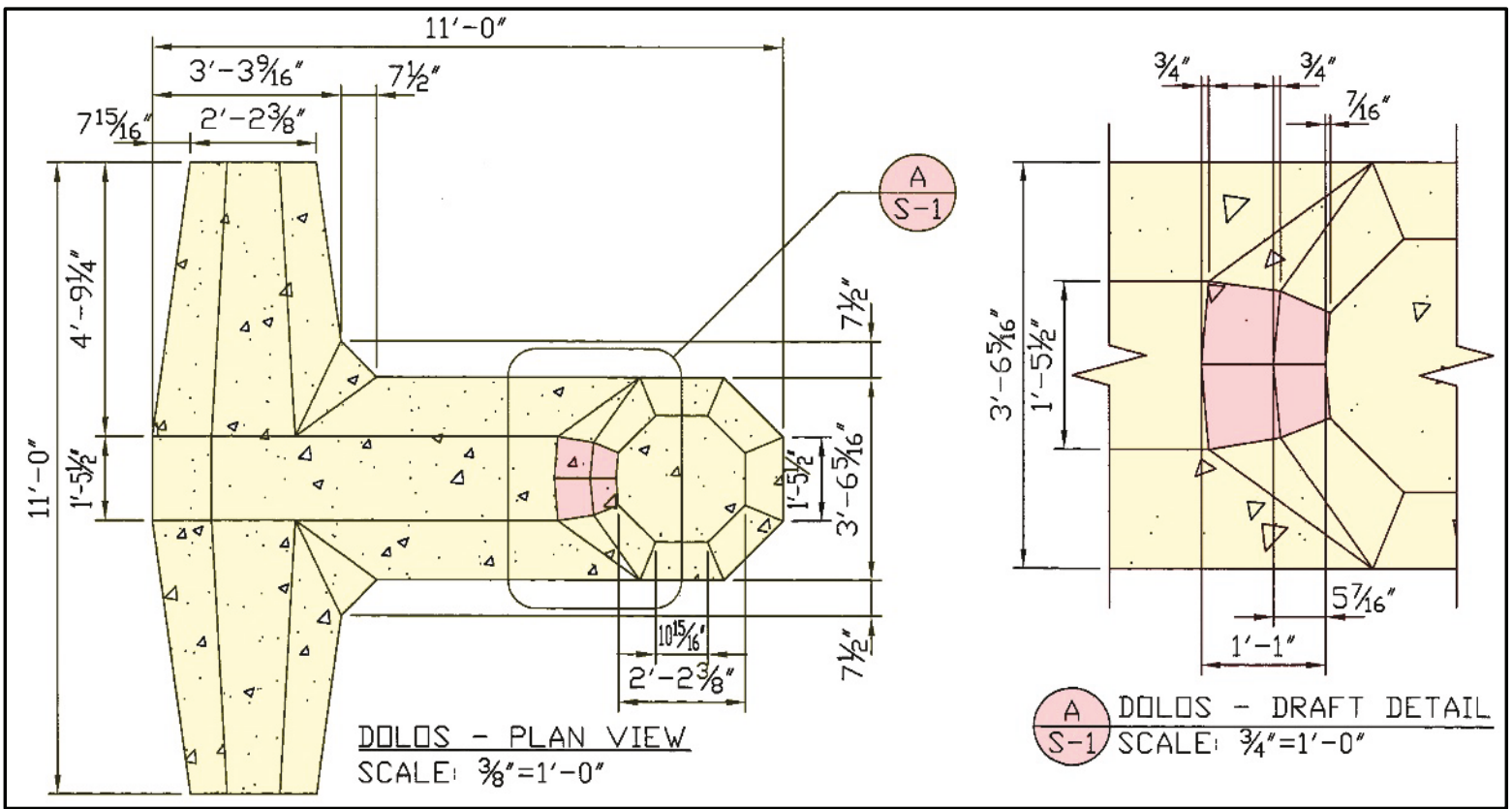




\section{Concrete mix}

The Anthony Allega Concrete Corporation formed the 6.5-ton dolosse for the Cleveland East Breakwater using the concrete mix presented in

Table 3-2.

Table 3-2. Cleveland 6.5-ton dolos concrete mix, $140 \mathrm{lb} / \mathrm{ft}^{3}$, no reinforcement.

\begin{tabular}{|l|c|l|}
\hline Material & Weight & Source \\
\hline Cement & $700 \mathrm{lb}$ & St. Marys Type 1, St. Marys, ON, Canada \\
\hline Fine Aggregate & $1,290 \mathrm{lb}$ & Natural sand, Shelly Materials, Mantua, OH \\
\hline Coarse Aggregate - \#8 Limestone & $652 \mathrm{lb}$ & Carmeuse Lime and Stone, Cedarville, MI \\
\hline Coarse Aggregate - \#57 Limestone & $978 \mathrm{lb}$ & Carmeuse Lime and Stone, Cedarville, MI \\
\hline BASF Masterair AE 2001 & $0.8 \mathrm{oz}$ & $\mathrm{N} / \mathrm{A}$ \\
\hline BASF Masterglenium 7710² & $8.2 \mathrm{oz}$ & Local \\
\hline Water & $266 \mathrm{lb}(31.9$ gallons $)$ & \\
\hline
\end{tabular}

${ }_{1}^{1}$ MasterAir AE 200 is an air entraining admixture, conforming to ASTM C260, that imparts improved resistance to damage from cyclic freezing and thawing. (Found at https://www.master-builders-solutions.basf.us/enus/products/masterair/1497.)

2BASF Masterglenium7710 is an admixture that provides fast setting and high-early compressive strength development. MasterGlenium 7710 admixture meets ASTM C494 compliance requirements for Type A, waterreducing, and Type F, high-range water-reducing, admixtures. (Found at https://www.master-builderssolutions.basf.us/en-us/products/masterglenium/1729.)

\section{Lakeland Concrete Corporation formed the 16-ton dolosse for the Oswego Detached Breakwater using the concrete mix presented in Table 3-3.}

Table 3-3. Oswego 16-ton dolos concrete mix, $150 \mathrm{lb} / \mathrm{ft}^{3}$, steel reinforcement.

\begin{tabular}{|l|c|l|}
\hline Material & Weight & Source \\
\hline Cement & $560 \mathrm{lb}$ & Lafarge Type III, Bath, ON, Canada \\
\hline Slag & $140 \mathrm{lb}$ & Lafarge, Stoney Creek, ON, Canada \\
\hline Fine Aggregate & $1,500 \mathrm{lb}$ & Hanson Aggregates, Victor, NY \\
\hline Coarse Aggregate (\#1's) & $1,410 \mathrm{lb}$ & Hanson Aggregates, Victor, NY \\
\hline ADVA 5851 & $56 \mathrm{oz}$ & W.R. Grace \& Co., North Bergen, NJ \\
\hline Daravair 10002 & $13.65 \mathrm{oz}$ & W.R. Grace \& Co., North Bergen, NJ \\
\hline Water & $275 \mathrm{lb}(33.0 \mathrm{gallons})$ & Town of Lima, NY \\
\hline Water/Cement Ratio & 0.4 & N/A \\
\hline
\end{tabular}

${ }_{1}^{1} A D V A \circledast$ Cast 585 high-range water reducer imparts improved workability to the concrete (enhanced concrete cohesiveness with low viscosity for rapid placement) and to also achieve high early compressive strength. Meets requirements of ASTM C494 Type A and F admixture. (Found at https://www.beyondconstruction.com/beyond-knowledge/article/grace-construction-adva-cast-57514747.html.)

${ }^{2}$ Daravair ${ }^{\circledR} 1000$ is a liquid air-entraining admixture, conforming to ASTM C260, that provides freeze-thaw resistance, yield control, and finishability performance. (Found at http://www.buildsite.com/pdf/wrgrace/Daravair-1000-Product-Data-447803.pdf.) 


\section{Concrete testing}

Concrete was tested according to the schedule presented in Table 3-4.

Table 3-4. Concrete testing requirements.

\begin{tabular}{|c|c|c|}
\hline Test & Cleveland & Oswego \\
\hline $\begin{array}{l}\text { Slump - } \\
\text { ASTM C143/C143M } \\
\text { (ASTM 2012b) }\end{array}$ & $\begin{array}{l}\text { Each } 150 \mathrm{yd}^{3} \text { of concrete } \\
\text { produced or once a day. }\end{array}$ & $\begin{array}{l}\text { Each } 150 \mathrm{yd}^{3} \text { of concrete } \\
\text { produced or once a day. }\end{array}$ \\
\hline $\begin{array}{l}\text { Temperature - } \\
\text { ASTM C1064/C1064M } \\
\text { (ASTM 2011) }\end{array}$ & $\begin{array}{l}\text { Test whenever slump, air, or } \\
\text { compressive tests are made. }\end{array}$ & $\begin{array}{l}\text { Test whenever slump, air, or } \\
\text { compressive tests are made. }\end{array}$ \\
\hline $\begin{array}{l}\text { Compressive Strength - ASTM } \\
\text { C31/C31M (ASTM 2012e); } \\
\text { ASTM C192/C192M (ASTM } \\
\text { 2012d); ASTM C39/C39M } \\
\text { (ASTM 2012f) }\end{array}$ & $\begin{array}{l}\text { Make at least four compressive } \\
\text { strength specimens for each } \\
150 \mathrm{yd}^{3} \text { of concrete, but not less } \\
\text { often than once per day. }\end{array}$ & $\begin{array}{l}\text { Make at least four compressive } \\
\text { strength specimens for each } \\
150 \mathrm{yd}^{3} \text { of concrete, but not less } \\
\text { often than once per day. }\end{array}$ \\
\hline $\begin{array}{l}\text { Flexural Strength - ASTM } \\
\text { C31/C31M (ASTM 2012e); } \\
\text { ASTM C192/C192M (ASTM } \\
\text { 2012d); ASTM C78/C78M } \\
\text { (ASTM 2013) }\end{array}$ & $\begin{array}{l}\text { Make at least four flexural } \\
\text { strength specimens for each } \\
150 \mathrm{yd}^{3} \text { of concrete, but not less } \\
\text { often than once per day. }\end{array}$ & $\mathrm{N} / \mathrm{A}$ \\
\hline $\begin{array}{l}\text { Air Content - } \\
\text { ASTM C231/C231M (ASTM } \\
\text { 2010) or ASTM C173/C173M } \\
\text { (ASTM 2012C) }\end{array}$ & $\begin{array}{l}\text { Test each } 150 \mathrm{yd}^{3} \text {, but not less } \\
\text { often than once per day. }\end{array}$ & $\begin{array}{l}\text { Test each } 150 \mathrm{yd}^{3} \text {, but not less } \\
\text { often than once per day. }\end{array}$ \\
\hline $\begin{array}{l}\text { Unit Weight - } \\
\text { ASTM C138/C138M (ASTM } \\
\text { 2012a) }\end{array}$ & $\begin{array}{l}\text { Test a minimum of once per } \\
\text { week to verify the yield of batch } \\
\text { mixes. }\end{array}$ & $\begin{array}{l}\text { Test a minimum of once per week } \\
\text { to verify the yield of batch mixes. }\end{array}$ \\
\hline
\end{tabular}

For the Cleveland dolosse, so that the manufacturer could safely remove from the forms each half day ( $12 \mathrm{hr}$ ), the mix was modified to result in higher early strength. The resulting unit weight of $147 \mathrm{lb} / \mathrm{ft} 3$ was slightly higher than the design unit weight of $140 \mathrm{lb} / \mathrm{ft}^{3}$, resulting in an actual dolos weight of 6.8 tons. The mean 28-day compressive strength of $6,562 \mathrm{lb} / \mathrm{in}^{2}{ }^{2}$ was $130 \%$ of the minimum required. Table $3-5$ presents the 28-day compressive strength descriptive statistics, and Figure 3-18 shows a histogram of the compressive strength results. 
Table 3-5. Cleveland dolos 28-day compressive strength test statistics.

\begin{tabular}{|l|c|}
\hline Mean & 6,562 \\
\hline Standard Error & 33 \\
\hline Median & 6,549 \\
\hline Mode & 6,980 \\
\hline Standard Deviation & 777 \\
\hline Sample Variance & 603,855 \\
\hline Kurtosis & 4 \\
\hline Skewness & 1 \\
\hline Range & 7,564 \\
\hline Minimum & 1,046 \\
\hline Maximum & 8,610 \\
\hline Sum & $3,701,051$ \\
\hline Count & 564 \\
\hline
\end{tabular}

Figure 3-18. Cleveland dolos 28-day compressive strengths.

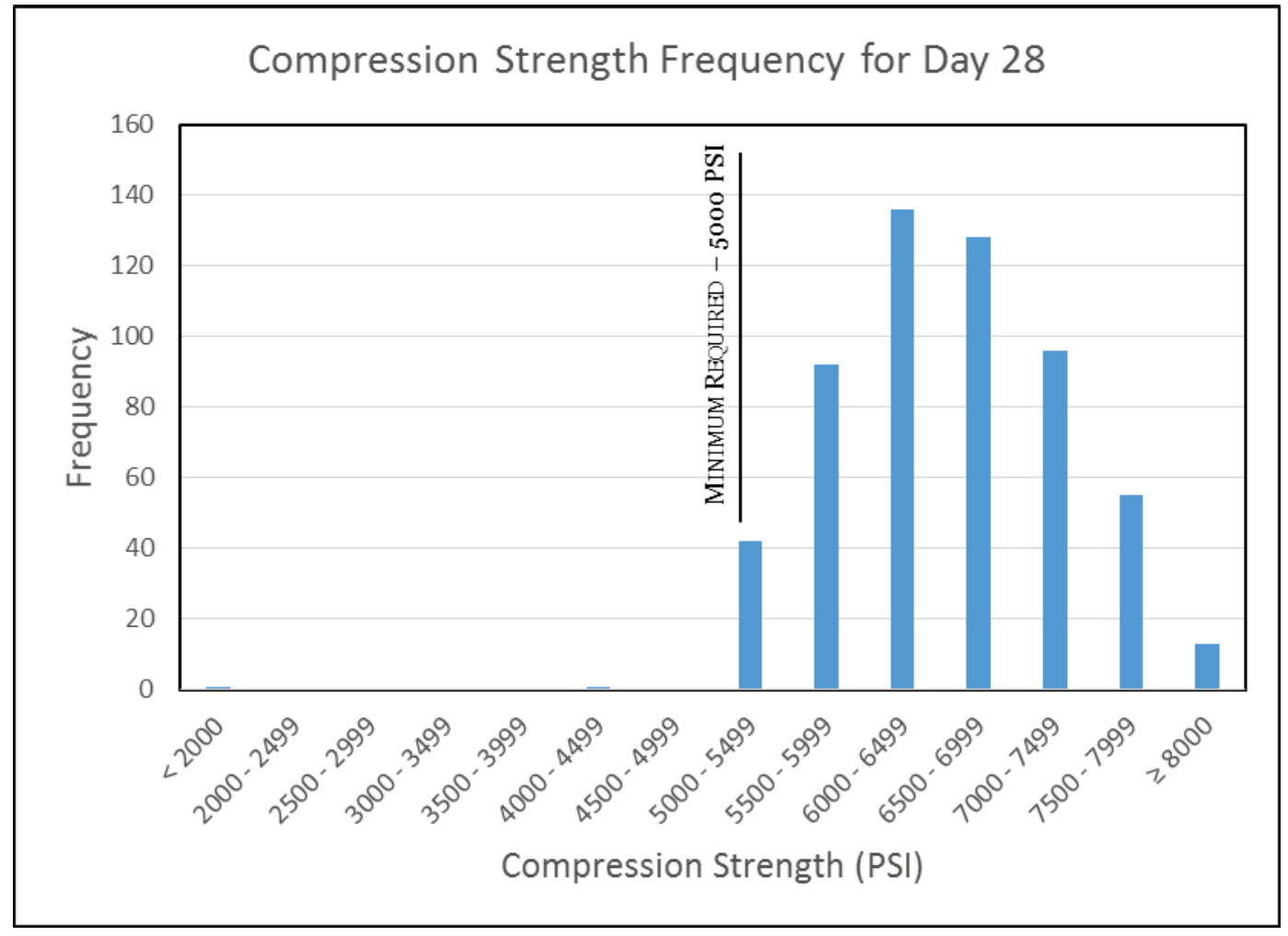


The actual mean 28 -day flexural strength of $1,192 \mathrm{lb} /$ in. $^{2}$ was more than double the minimum required tensile strength of $500 \mathrm{lb} / \mathrm{in}^{2}{ }^{2}$. Table 3-6 presents the 28-day compressive strength descriptive statistics, and Figure 3-19 is a histogram of the flexural strength results. Figure 3-20 presents a plot of actual measured flexural versus compressive strengths with the American Concrete Institute (ACI) equation also shown. Figure 3-21 presents a photo of the testing equipment with a failed specimen at $1,302 \mathrm{lb} / \mathrm{in}^{2}$.

Table 3-6. Cleveland dolos 28-day flexural strength test statistics.

\begin{tabular}{|l|c|}
\hline Mean & 1,192 \\
\hline Standard Error & 4 \\
\hline Median & 1,197 \\
\hline Mode & 1,244 \\
\hline Standard Deviation & 104 \\
\hline Sample Variance & 10,826 \\
\hline Kurtosis & 4 \\
\hline Skewness & 0 \\
\hline Range & 980 \\
\hline Minimum & 855 \\
\hline Maximum & 1,836 \\
\hline Sum & 674,686 \\
\hline Count & 566 \\
\hline
\end{tabular}


Figure 3-19. Cleveland dolos 28-day flexural strengths.

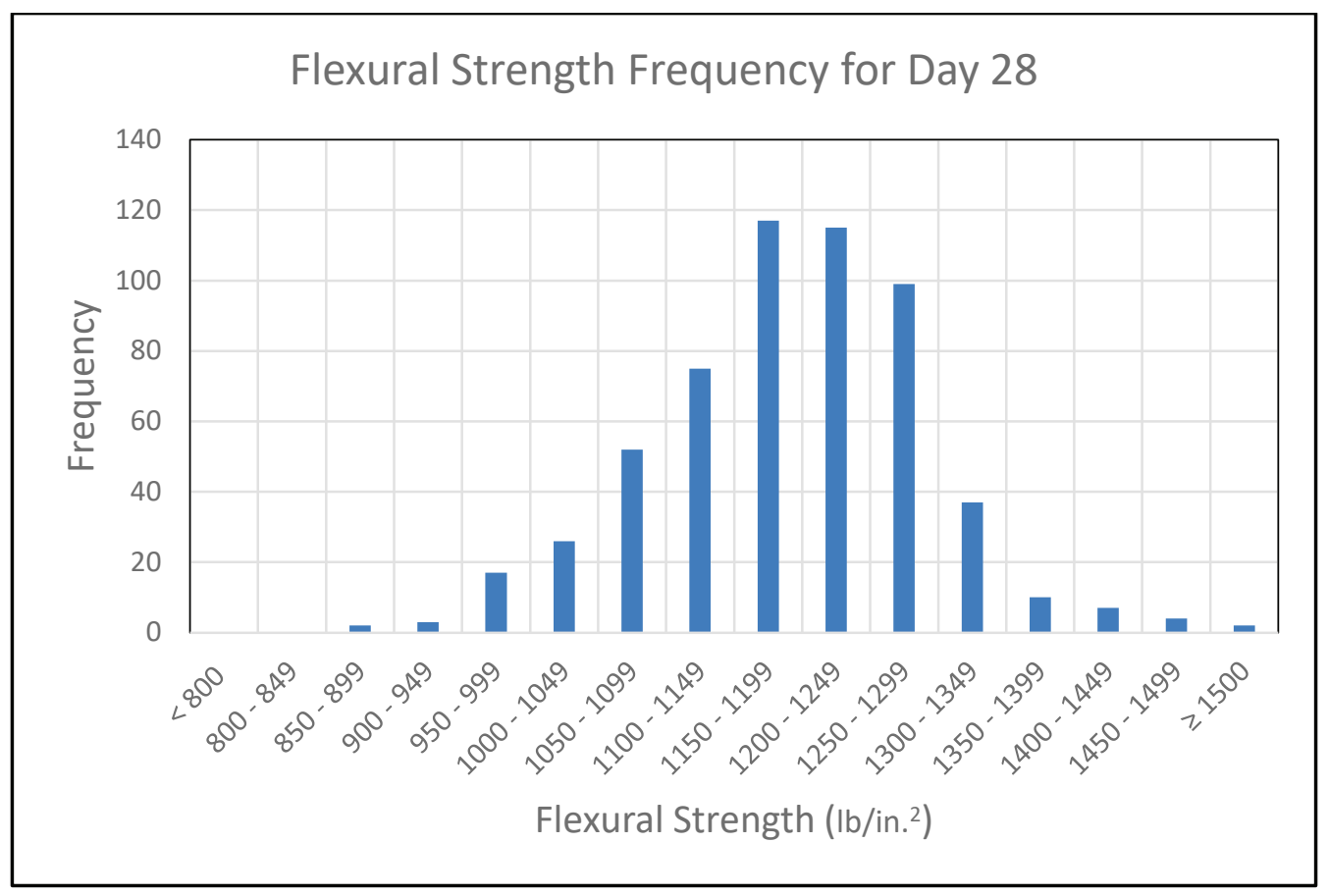

Figure 3-20. Cleveland dolos flexural versus compressive with comparison to $\mathrm{ACl}$ equation.

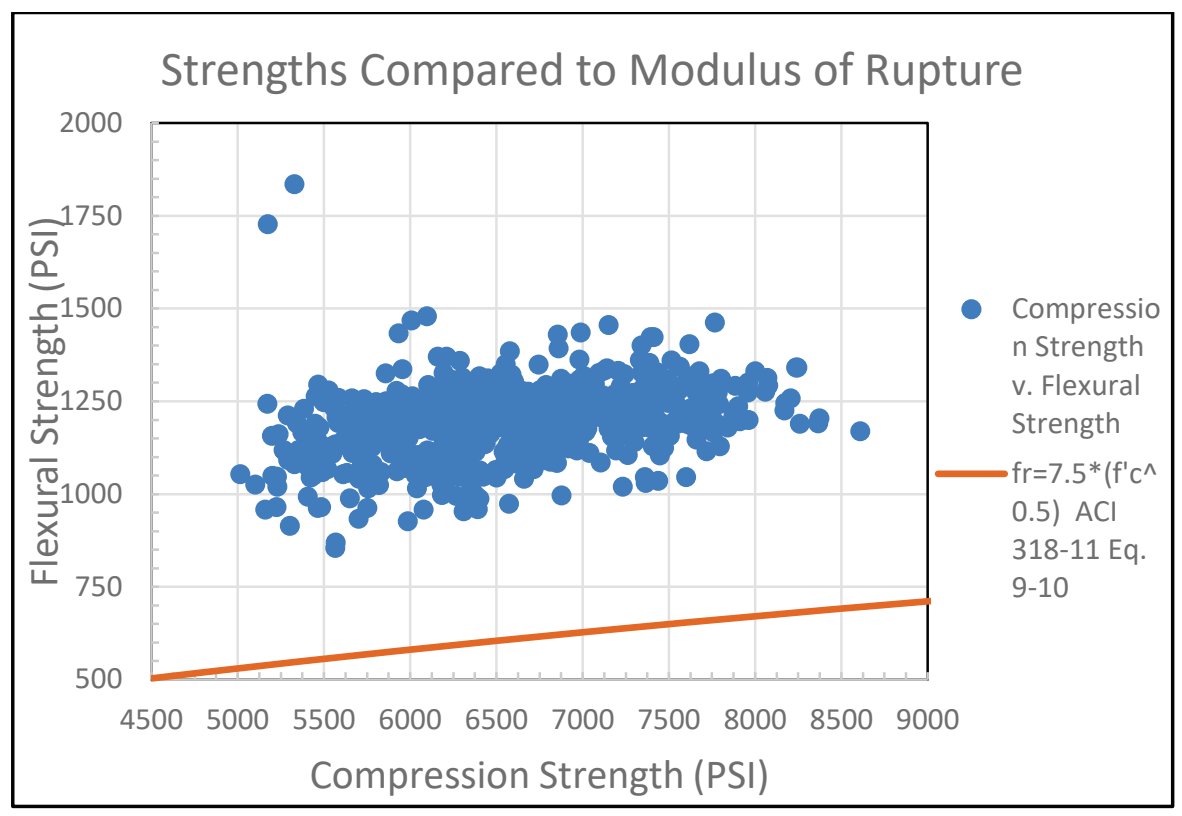


Figure 3-21. Cleveland dolos 28-day flexural strength test (sample failed at 1,302 lb/in.2).

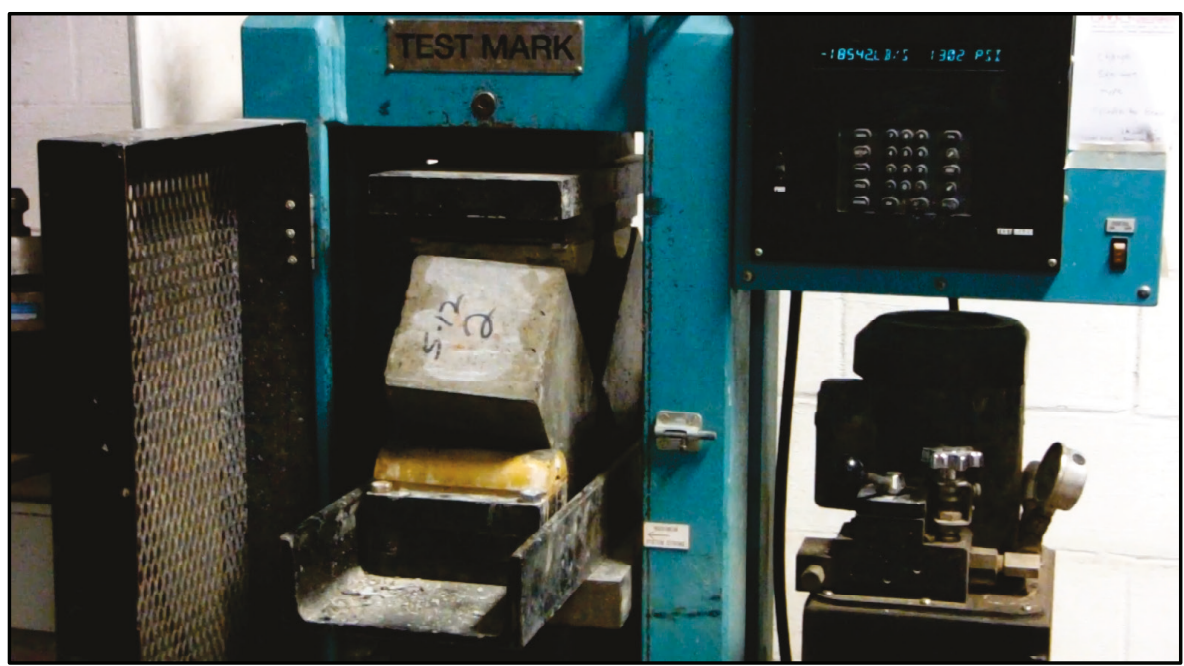

For the Oswego dolosse, so that the manufacturer could safely remove from the forms each day ( $24 \mathrm{hr}$ ), the mix was modified to result in a higher early strength. This resulted in a unit weight of $143.2 \mathrm{lb} / \mathrm{ft} 3$ for the concrete. For the 1-day compressive strengths, $26.7 \%$ of the tests were greater than the minimum required 28 -day strength of $5,000 \mathrm{lb} / \mathrm{in} .^{2}$, $99.7 \%$ were greater than the minimum by the eighth day, and all test results were greater than the minimum requirement by 28 days. The testing apparatus could only measure to $7,003 \mathrm{lb} / \mathrm{in} .^{2}$, and $96.2 \%$ of the 28-day strengths were greater than that value. Note that the quality assurance testing, which could measure values above 7,003 lb/in. ${ }^{2}$, indicated an average 28-day compressive strength of $8,580 \mathrm{lb} / \mathrm{in} .^{2}$, with test results ranging from $7,735 \mathrm{lb} / \mathrm{in}^{2}{ }^{2}$ to $9,690 \mathrm{lb} / \mathrm{in} .^{2}$. Table $3-7$ and Table 3-8 present a summary of dolos strengths greater than $5,000 \mathrm{lb} /$ in. $^{2}$ and 7,003 lb/in. ${ }^{2}$, respectively. The quality assurance tests results are presented in Figure 3-22. 
Table 3-7. Oswego dolos compressive strength tests greater than 5,000 lb/in. ${ }^{2}$.

\begin{tabular}{|c|c|c|c|c|c|}
\hline Days & $\begin{array}{c}\text { Number of } \\
\text { Tests }>5,000^{1}\end{array}$ & $\begin{array}{l}\text { Cumulative Number } \\
\text { of Tests }>5,000\end{array}$ & $\begin{array}{l}\text { Total Number } \\
\text { Tests }\end{array}$ & $\begin{array}{c}\text { Cumulative Total } \\
\text { Tests }\end{array}$ & $\begin{array}{c}\text { Cumulative Tests } \\
>5,000, \%\end{array}$ \\
\hline 1 & 209 & 209 & 783 & 783 & 26.69 \\
\hline 2 & 16 & 225 & 16 & 799 & 28.16 \\
\hline 3 & 182 & 407 & 190 & 989 & 41.15 \\
\hline 4 & 16 & 423 & 16 & 1005 & 42.09 \\
\hline 5 & 4 & 4 & 4 & 24 & \\
\hline 6 & 18 & 22 & 18 & 42 & \\
\hline 7 & 912 & 934 & 914 & 956 & \\
\hline 8 & 8 & 942 & 8 & 964 & 97.72 \\
\hline 27 & 14 & 659 & 14 & 659 & \\
\hline 28 & 356 & 1015 & 356 & 1015 & 100.00 \\
\hline
\end{tabular}

Note: Tested on day 1, 2, 3, or 4; and 5, 6, 7, or 8; and 27 or 28.

Table 3-8. Oswego dolos compressive strength tests greater than 7,003 lb/in. ${ }^{2}$.

\begin{tabular}{|c|c|c|c|c|c|}
\hline Days & $\begin{array}{c}\text { Number of Tests } \\
>7,003\end{array}$ & $\begin{array}{c}\text { Cumulative Number } \\
\text { of Tests }>7,003\end{array}$ & $\begin{array}{l}\text { Total Number } \\
\text { Tests }\end{array}$ & $\begin{array}{c}\text { Cumulative Total } \\
\text { Tests }\end{array}$ & $\begin{array}{c}\text { Cumulative Tests } \\
>7,003, \%\end{array}$ \\
\hline 1 & 0 & 0 & 783 & 783 & 0 \\
\hline 2 & 0 & 0 & 16 & 799 & 0 \\
\hline 3 & 12 & 12 & 190 & 989 & 1.21 \\
\hline 4 & 8 & 20 & 16 & 1005 & 1.99 \\
\hline 5 & 4 & 24 & 4 & 24 & \\
\hline 6 & 16 & 40 & 18 & 42 & \\
\hline 7 & 604 & 644 & 914 & 956 & \\
\hline 8 & 1 & 645 & 8 & 964 & 66.91 \\
\hline 27 & 14 & 659 & 14 & 659 & \\
\hline 28 & 317 & 976 & 356 & 1015 & 96.16 \\
\hline
\end{tabular}


Figure 3-22. Oswego dolos quality assurance compressive test results.

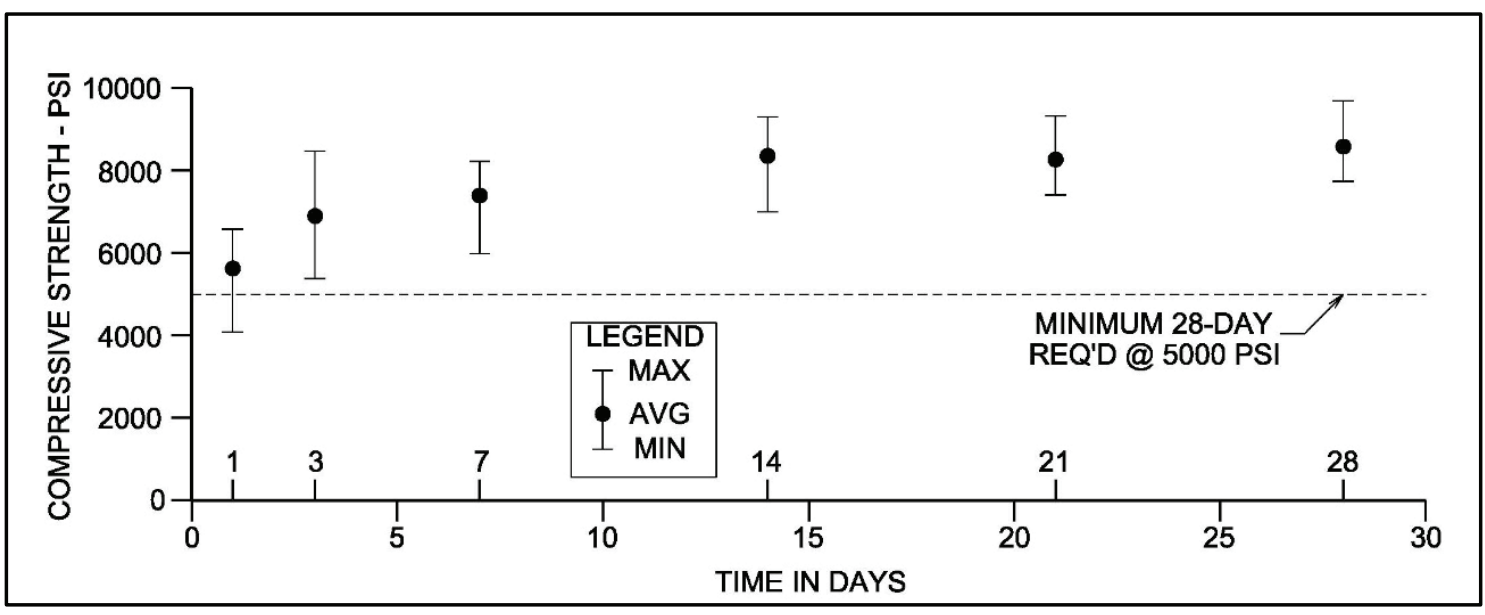

\section{Dolos transportation}

The Cleveland dolosse were transported by flatbed truck approximately 11 miles from the manufacturer to Port of Cleveland (Figure 3-23) where they were temporarily stored awaiting loading onto the contractor's barge. During this process, two dolosse were deemed unsuitable for placement, and two dolosse were broken in transit. Similarly, the Oswego dolosse were transported by flatbed truck approximately 90 miles from the manufacturer to the Port of Oswego (Figure 3-24) where they were temporarily stored awaiting loading onto the contractor's barge.

Figure 3-23. Dolosse at Port of Cleveland, Ohio.

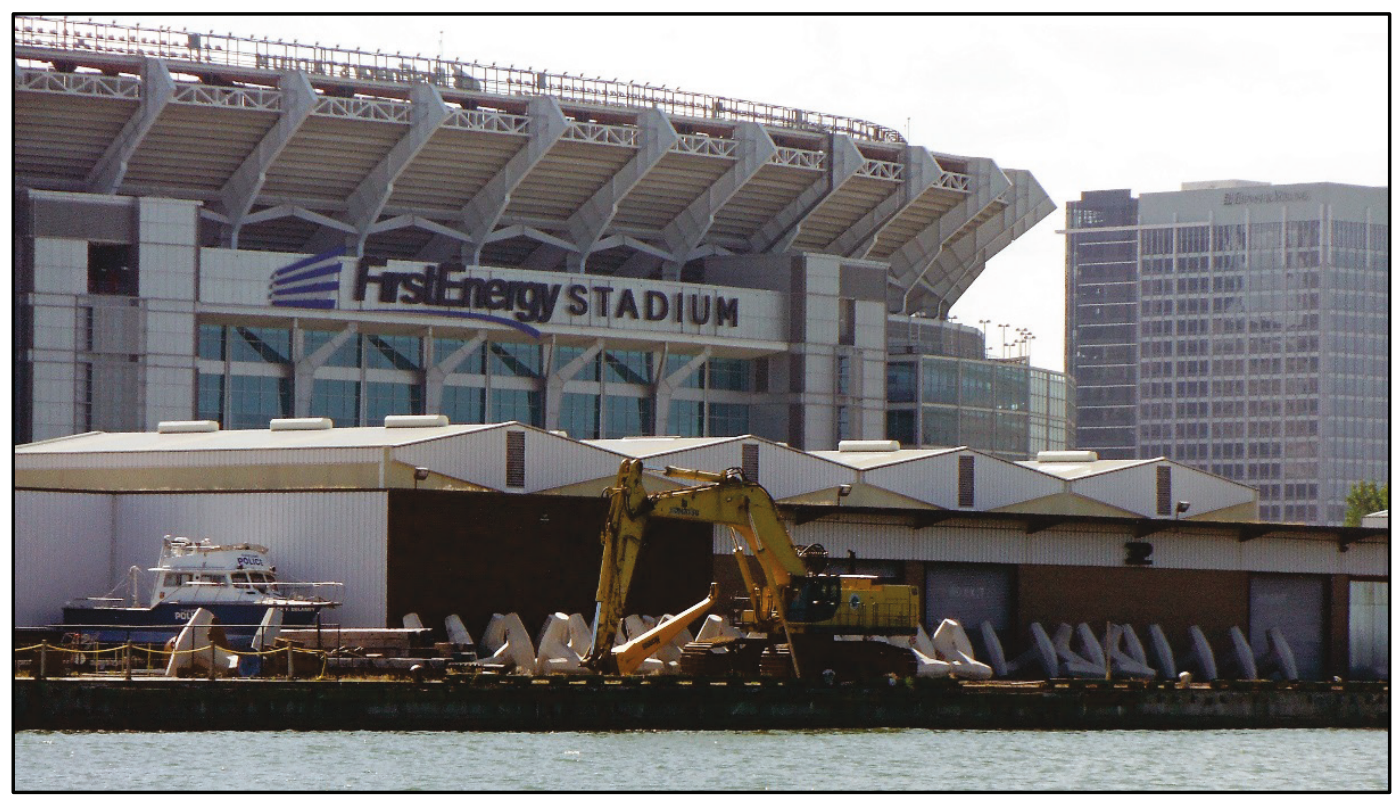


Figure 3-24. Dolosse at Port of Oswego, New York.

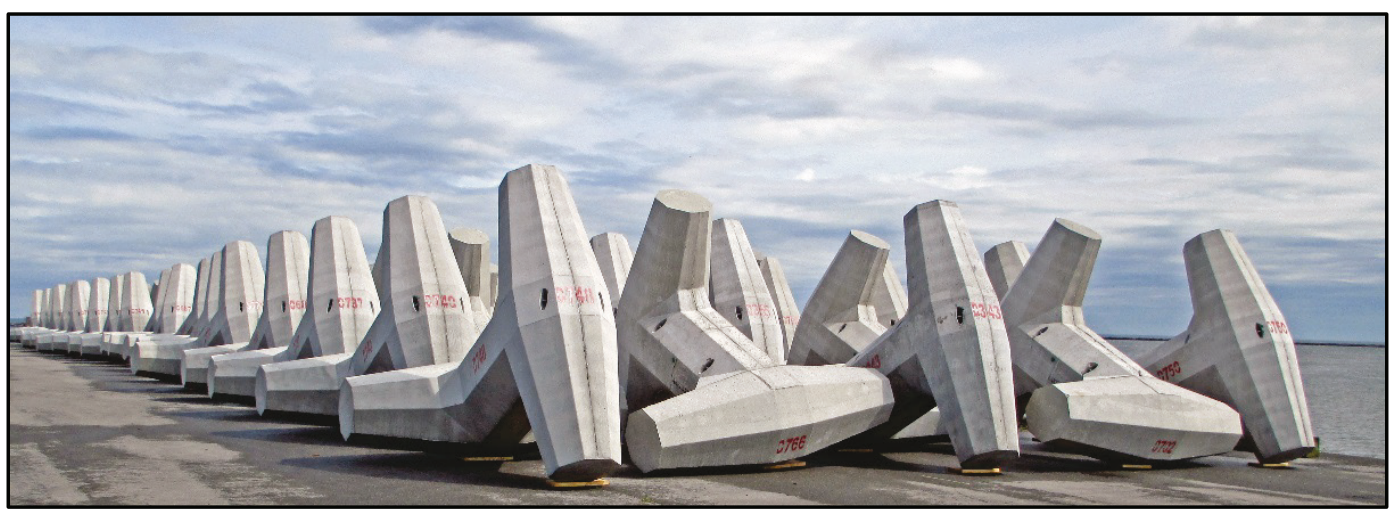




\section{Dolos Placement Techniques}

In addition to using quality materials, excellent placement is required to ensure a quality product. Since most of the dolos placement occurs underwater and is not visible, it was necessary to specify a method that would guarantee proper density, even distribution, and good interlocking (individual dolos orientation randomness) of the dolosse. Prior to fullscale placement operations, a $25 \mathrm{ft}$ length of breakwater was completed as a test of the proper placement and maximum interlocking of the dolosse. The contractor was not allowed to proceed until the test area was completed and approved by the government.

\section{Dolos placement system}

Each dolos had a number spray painted on it. The contractor was required to use an AUPPS when placing all dolosse. The system needed to combine Real Time Kinematic (RTK), Global Positioning System (GPS), and Global Navigation Satellite System (GLONASS) positioning technologies and attitude sensors to produce a three-dimensional (3D) image of the dolos units being placed in real time and be capable of guiding the crane operator to place dolosse in their designated positions with interlocking control. The system needed to be based on topography and not use acoustic communication or video. The system had to operate equally well above and under water to the same degree of accuracy, down to water depth in excess of $75 \mathrm{ft}$. There were to be no limitations when operating close to water surface. A $3 \mathrm{D}$ image of the unit in real time had to be simultaneously displayed on a monitor within the crane cab and on a wireless laptop away from the crane. The image resolution had to be constant and not affected by zooming. All viewing directions were to be possible. The complete armor unit placement and positioning system, including all components and software, had to be provided by a single company that had been manufacturing armor unit placement and positioning systems for a minimum of 5 years.

The AUPPS system basic requirements were that it contained, and integrated, the following:

1. A positioning reference station based on RTK, GPS, and GLONASS satellites.

2. A control and command system installed in the crane cabin.

3. A wireless laptop with WIFI communication. 
4. A reference frame, including cables orientation, verticality and distance measurement.

5. One recoverable and reusable measurement module for attitude measurement of each armor unit.

Although there were other software alternatives available, such as CodaOctopus $^{1}$, contractors for both projects selected the POSIBLOC ${ }^{\mathrm{TM}}$ system developed by MESURiS ${ }^{2}$, which met all of the aforementioned criteria, and is a topographical $3 \mathrm{D}$ system for optimum placement control of armor units above or below water. A recoverable attitude sensor (BIB [MESURiS term]) is attached to the armor unit prior to placement with three small plastic pins. The BIB has internal sensors and micro-controller software that has positional accuracy of 15 centimeters (cm) (5.9 in.) or $\mathrm{h} / 12$, whichever is greater $(\mathrm{h}=$ block height). Given dolos dimensions of $8.33 \mathrm{ft}$ and $11 \mathrm{ft}$, the estimated positional accuracy is $8.3 \mathrm{in}$. and $11 \mathrm{in}$. for the Cleveland and Oswego dolosse, respectively. To recover the BIB after the unit has been placed, the quick release hook is activated, and the POSIBLOC sling removes the BIB from the dolos, following the lifting of the main sling (Mouquet 2009). During placement, the crane operator and the Placement Plan Control Specialist could see the 3D image of the unit being placed in real time in addition to seeing previously placed units and the target points for dolosse not yet placed. A position indicator showed the $x, y, z$ differences between the real-time and target coordinates.

Coupled with the VISIBLOC ${ }^{\mathrm{TM}}$ software, each dolos trajectory was monitored and recorded, out-of-profile units detected, the placement density for any selected area determined, screenshots of dolosse in any direction generated, the center of gravity coordinates stored for each placed dolos unit along with attitude and conditions of placing (positioning quality, speed, first or last attitude selected), and the time and date stored for each dolos unit placed.

Figure 4-1 shows the general POSIBLOC system. Figure 4-2 is a typical view from the crane during the Oswego construction. Figure 4-3 is a closeup view of the operator's computer screen.

\footnotetext{
${ }^{1}$ Coda Octopus Products Limited, 38 South Gyle Crescent, Edinburgh, EH12 9EB, UK, http://www.codaoctopus.com/products/usehttp\%3A

2 MESURiS, 37 rue de l'Océan - 56470 SAINT-PHILIBERT - FRANCE, http://www.mesuris.com/en/systems-2/posibloc.html
} 
Figure 4-1. POSIBLOC system.

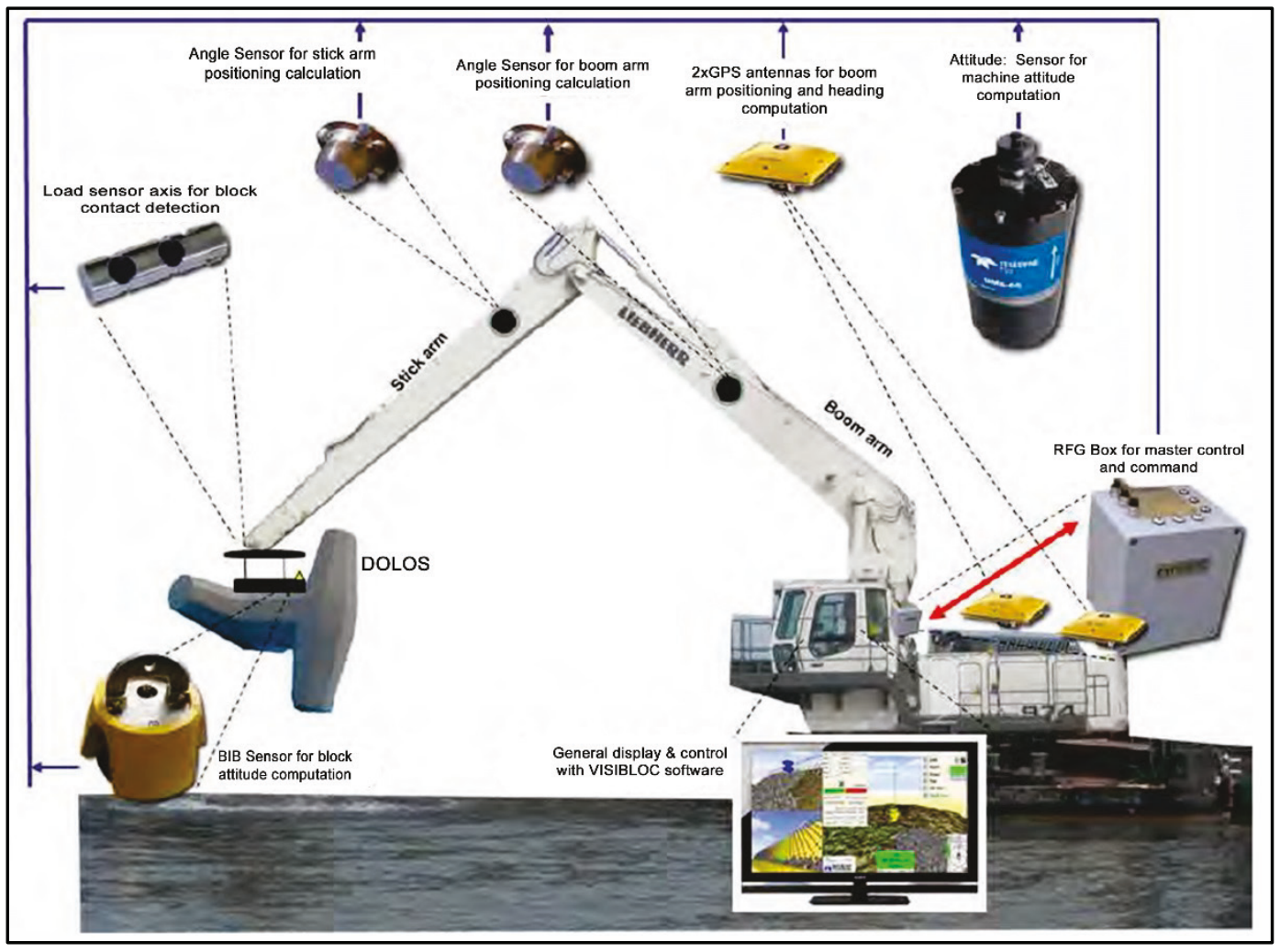

Figure 4-2. Crane operator's view of Oswego dolos placement.

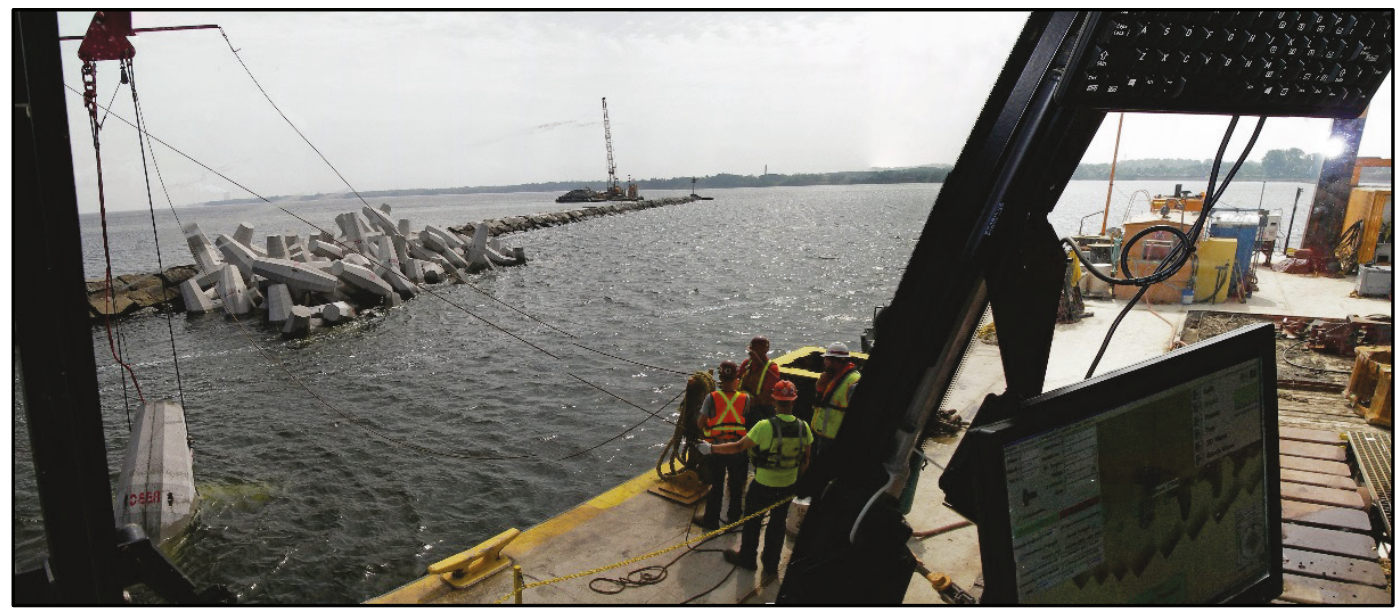


Figure 4-3. Crane operator's view of computer screen during Oswego dolos placement.

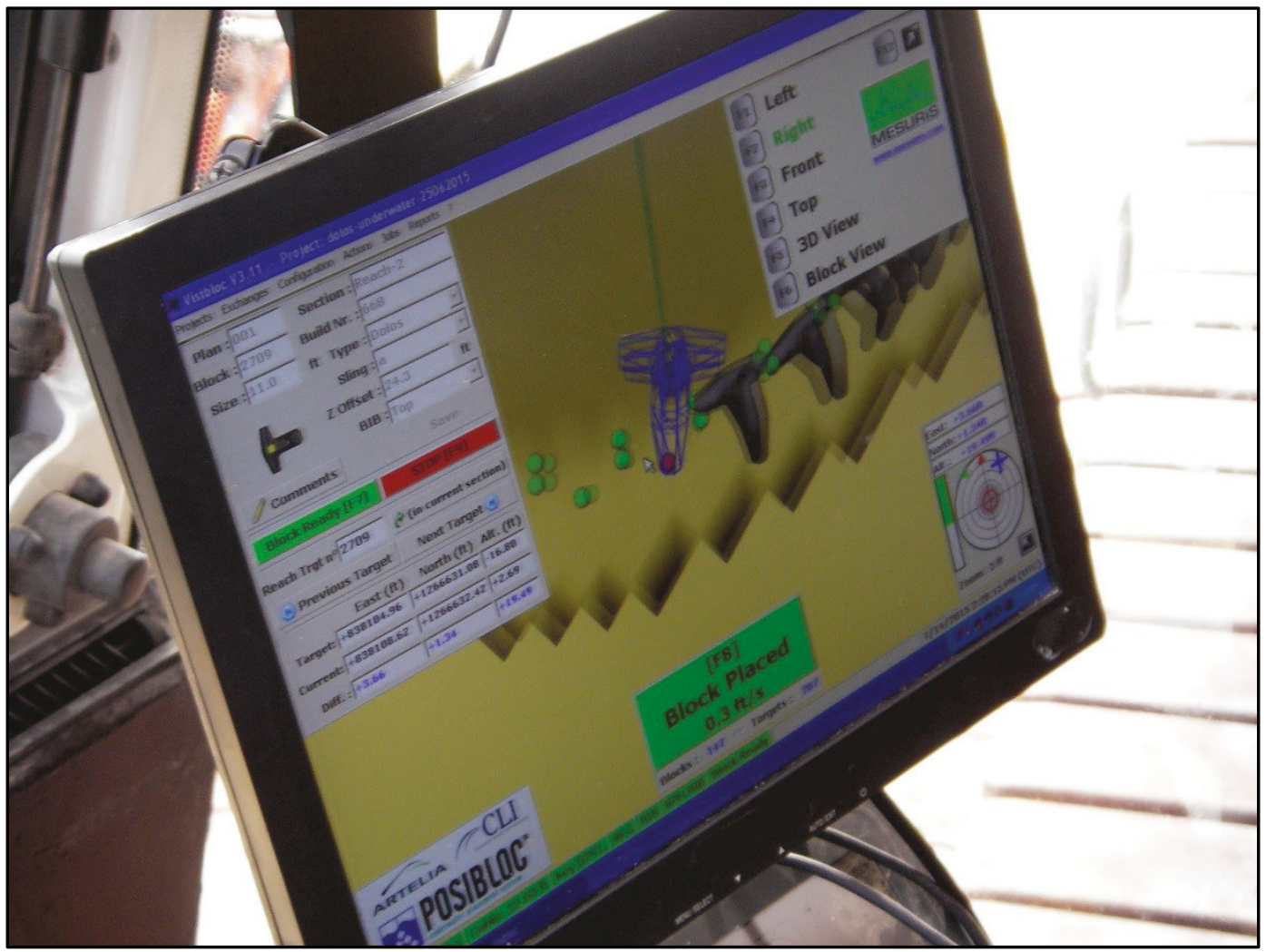

The contractors were also required to (1) use the provided EXCEL spreadsheet to determine the dolosse placed in each $25 \mathrm{ft}$ length of breakwater by quarters, (2) track the number of placed dolosse and their coordinates, and (3) calculate the density of the placed dolosse. A separate table for each $25 \mathrm{ft}$ length was updated daily and divided into quarters as shown in Figure 4-4.

Figure 4-4. Cleveland Breakwater repair section definition of estimated quarter lengths.

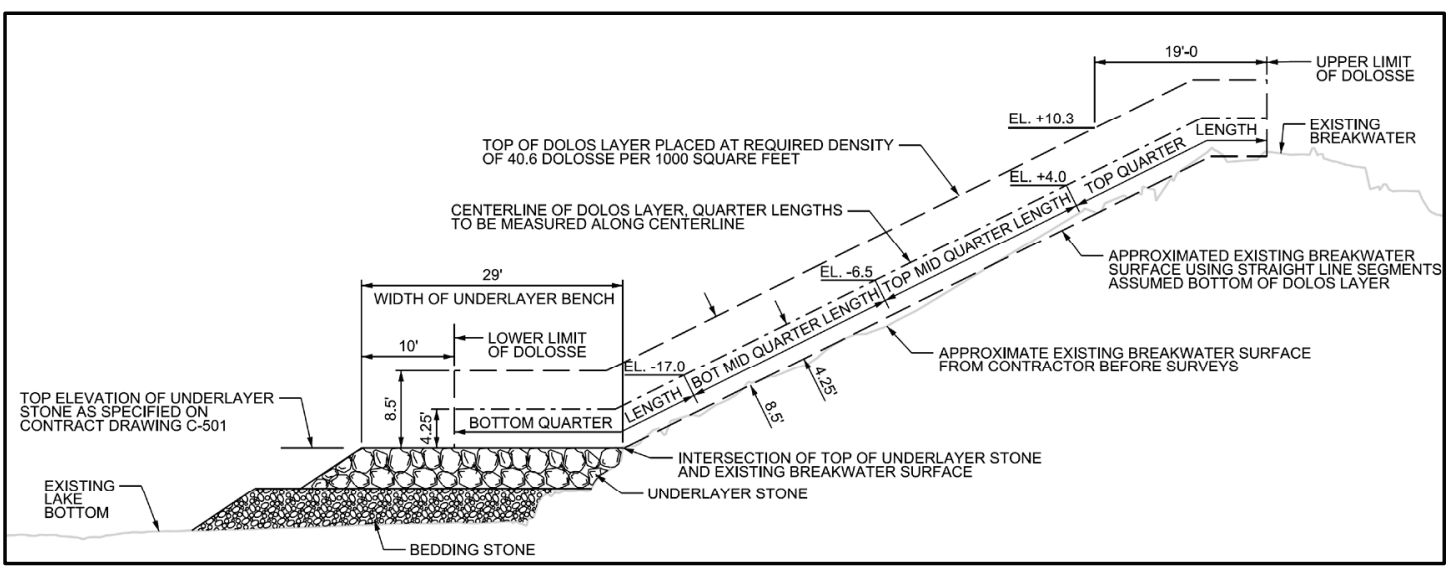


The contractor plotted each placed dolos daily as shown on the typical template presented in Figure 4-5. For Cleveland, the dolosse had to be placed at an average density of 40.6 per $1,000 \mathrm{ft}^{2}$ with a minimum density of 38.6 per $1000 \mathrm{ft}^{2}$, but no more than a maximum of 42.6 per $1000 \mathrm{ft}^{2}$. To ensure maximum interlocking, each quarter could not reach the required density until dolosse were placed at least $5 \mathrm{ft}$ into the adjoining quarter (both within the $25 \mathrm{ft}$ length and adjoining $25 \mathrm{ft}$ lengths), where possible. As each quarter was completed, any dolos density outside of the acceptable dolos density tolerance was to be brought to the immediate attention of the government. Extreme limits of the density tolerance were not to be continuous over an area greater than $1000 \mathrm{ft}^{2}$. If the density were below the tolerance, then the government could direct the contractor to place additional dolosse, at the contract bid item price. If the density were above the tolerance, then the extra dolosse placed would be at no cost to the government. For Oswego, the required density of dolosse was 23.3 dolosse per $1,000 \mathrm{ft}^{2}$ with a tolerance of \pm 1 dolos per $1,000 \mathrm{ft}^{2}$.

Figure 4-5. Cleveland plan of placed dolos centers of gravity.

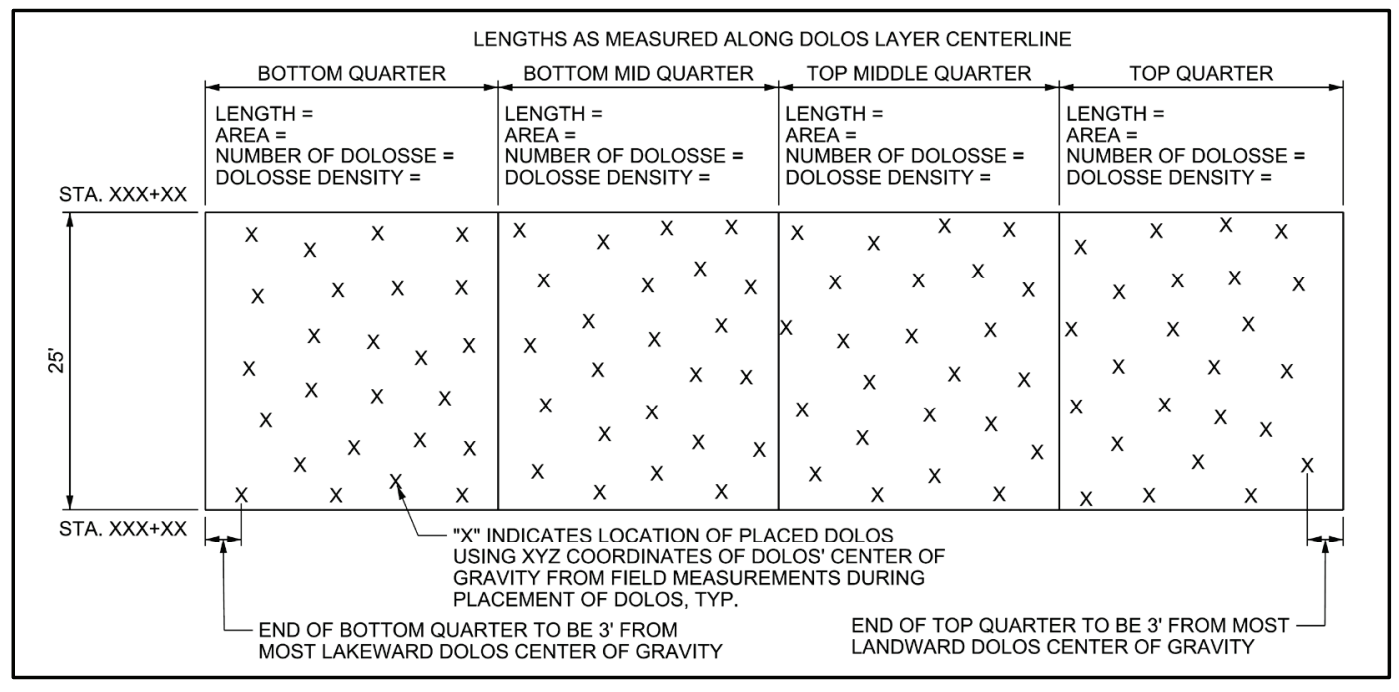

Since the bottom row of Oswego dolosse were specially oriented to ensure slope stability, an additional requirement for placement tolerance was specified as illustrated in Figure 4-6. 
Figure 4-6. Allowable offsets for the placement of the first row of Oswego dolosse.

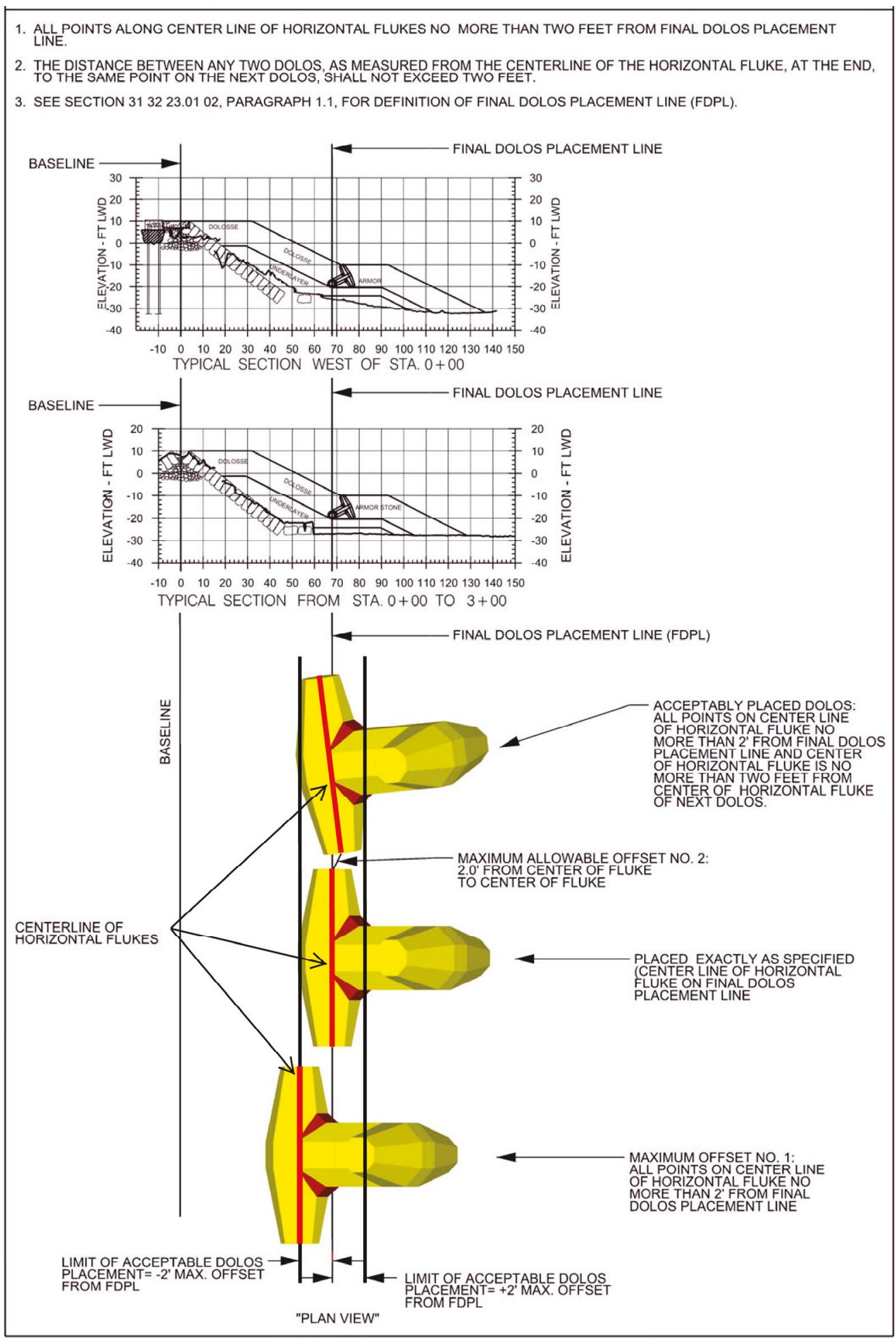


The actual placement values for the bottom row of the Oswego dolosse are presented in Table 4-1.

Table 4-1. Oswego first-row placement descriptive statistics.

\begin{tabular}{|l|c|c|}
\hline Statistic & $\begin{array}{c}\text { Distance from End 1 } \\
\text { and Final Dolosse } \\
\text { Placement Line }\end{array}$ & $\begin{array}{c}\text { Distance from End 2 } \\
\text { and Final Dolosse } \\
\text { Placement Line }\end{array}$ \\
\hline Mean & 1.016 & 1.283 \\
\hline Standard Error & 0.099 & 0.105 \\
\hline Median & 1.05 & 1.5 \\
\hline Mode & 1.3 & 1.6 \\
\hline Standard Deviation & 0.765 & 0.811 \\
\hline Sample Variance & 0.585 & 0.657 \\
\hline Kurtosis & -0.653 & -0.099 \\
\hline Skewness & 0.197 & -0.355 \\
\hline Range & 3.3 & 4.0 \\
\hline Minimum & -0.6 & -1.0 \\
\hline Maximum & 2.7 & 3.0 \\
\hline Sum & 60.93 & 77.0 \\
\hline Count & 60 & 60 \\
\hline
\end{tabular}

\section{Dolos placement equipment}

Prior to placement of the dolosse, the BIB (sensor for block attitude computation) was calibrated on the first unit of the day to ensure the system was recording properly (Figure 4-7).

Figure 4-7. Calibrating BIB on Oswego dolos.

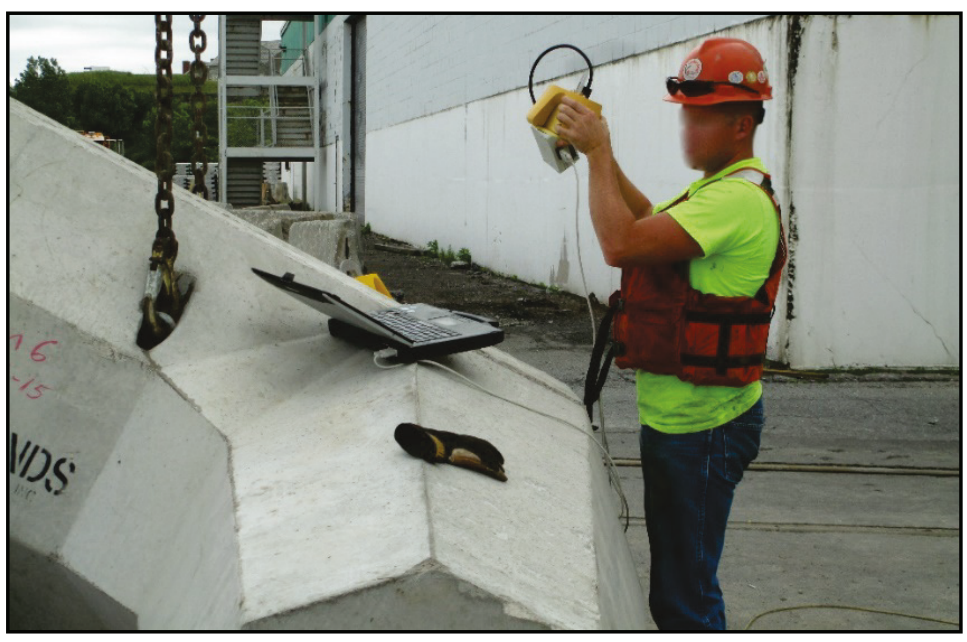


For the Cleveland dolosse, the contractor created a special lifting mechanism that used a hydraulic cam system to tighten and release the lifting cables. This unit also housed the BIB (Figure 4-8). For the lifting assembly to be placed at the same location on the dolos, the saddle (positioning jig) was first placed, and then the lifting mechanism was butted up against this template. Figure 4-9 through Figure 4-13 present a sequence of views captured from video that show a dolos being placed. Note the saddle in Figure 4-9, which is subsequently removed (Figure 4-10) once the lifting cables are taut.

Figure 4-8. Cleveland dolos lifting arrangement.

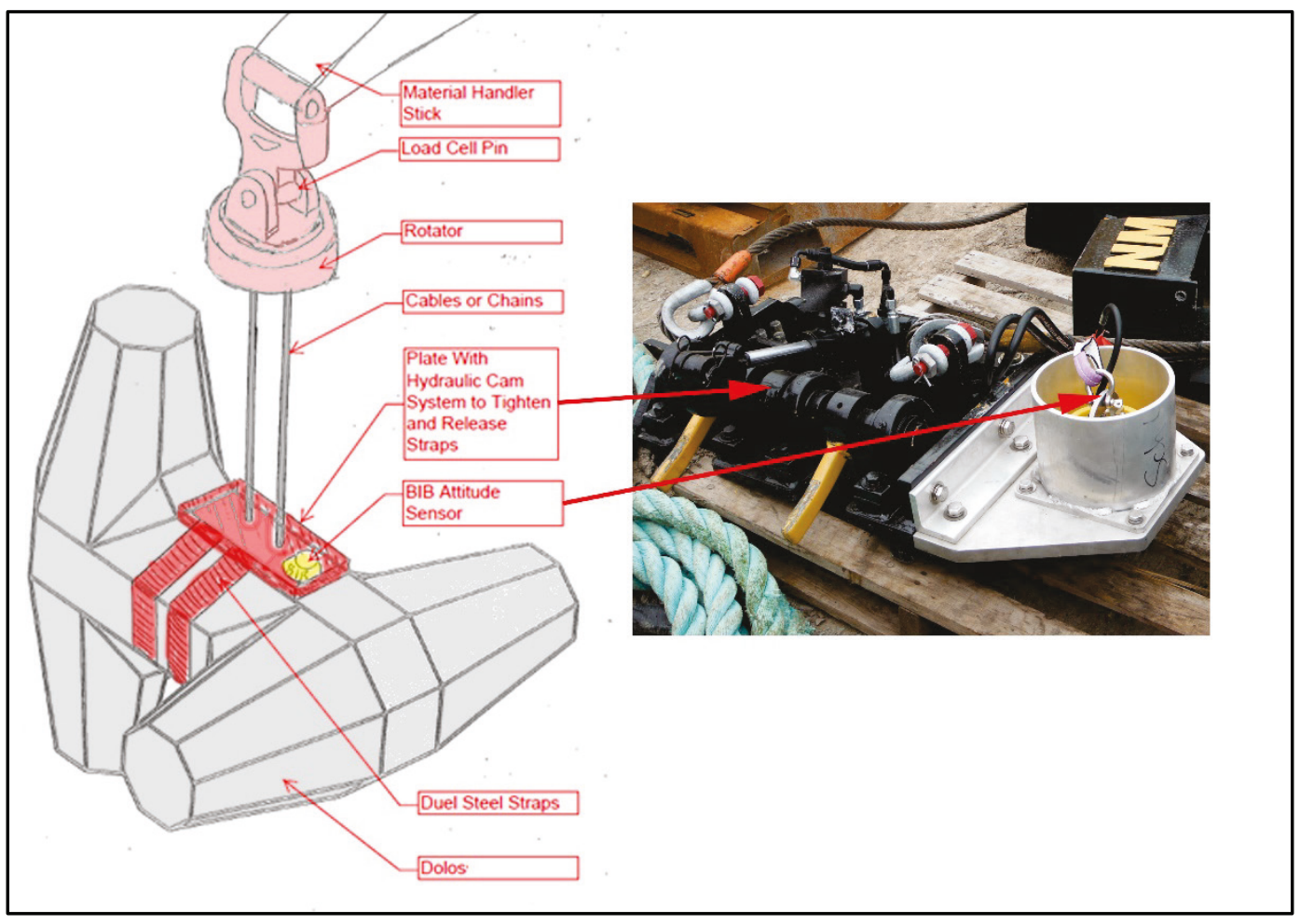


Figure 4-9. Aligning Cleveland dolos lifting mechanism with saddle (video time 0:00 minute:second [min:sec]).

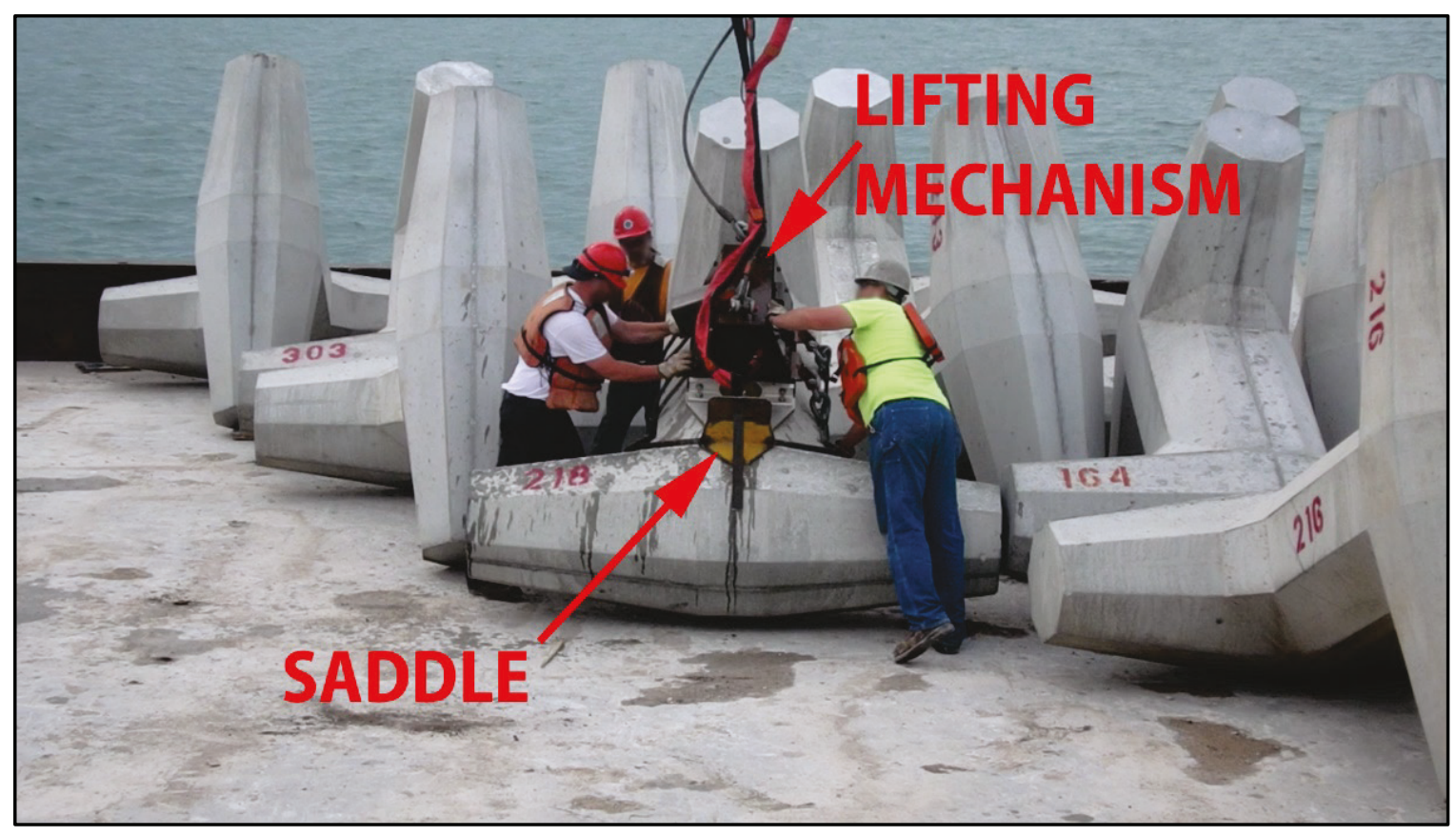

Figure 4-10. Removing saddle from Cleveland dolos prior to lifting (video time 0:21 min:sec).

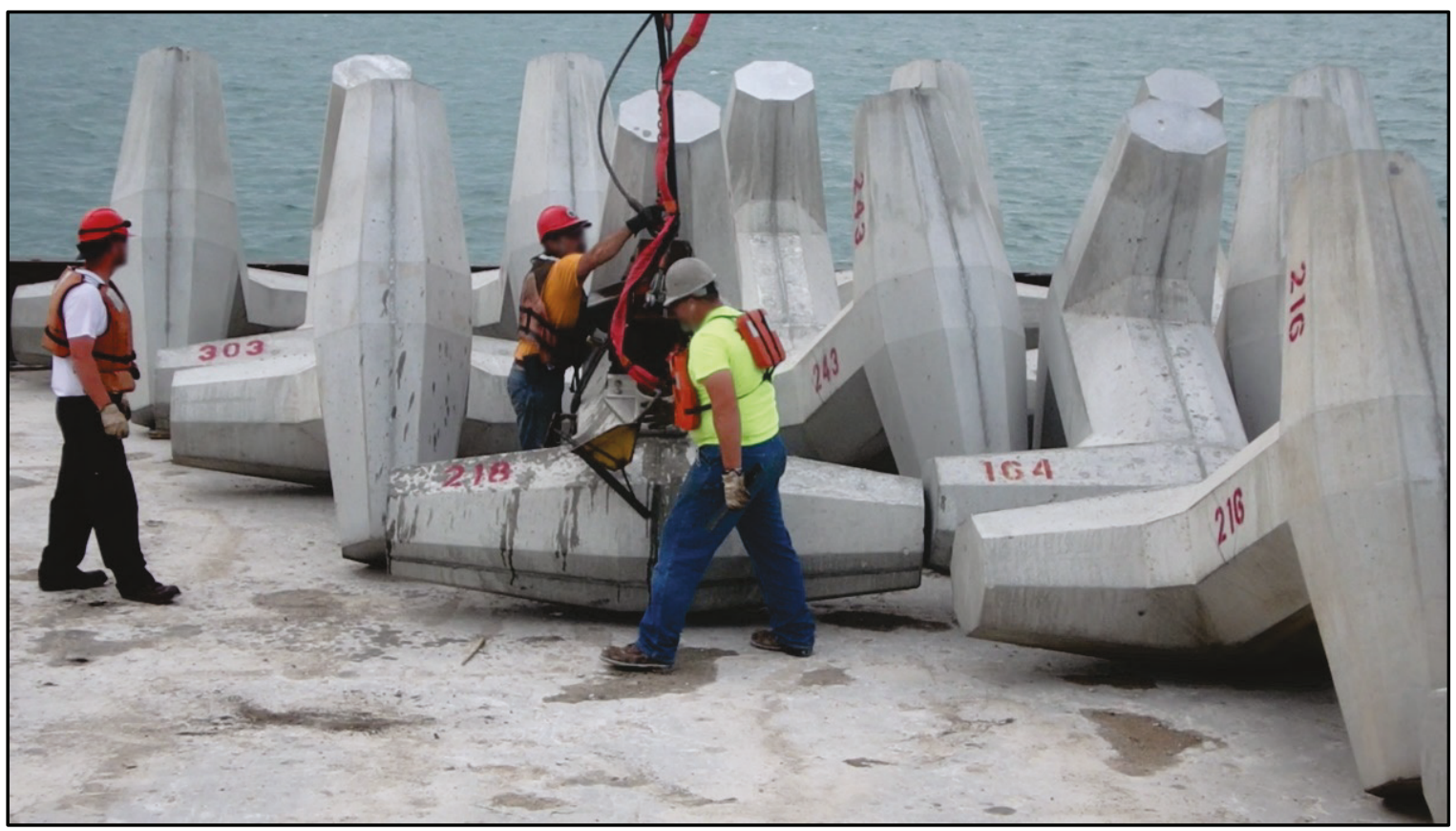


Figure 4-11. Placing saddle from Cleveland dolos at toe of section (video time 1:32 min:sec).

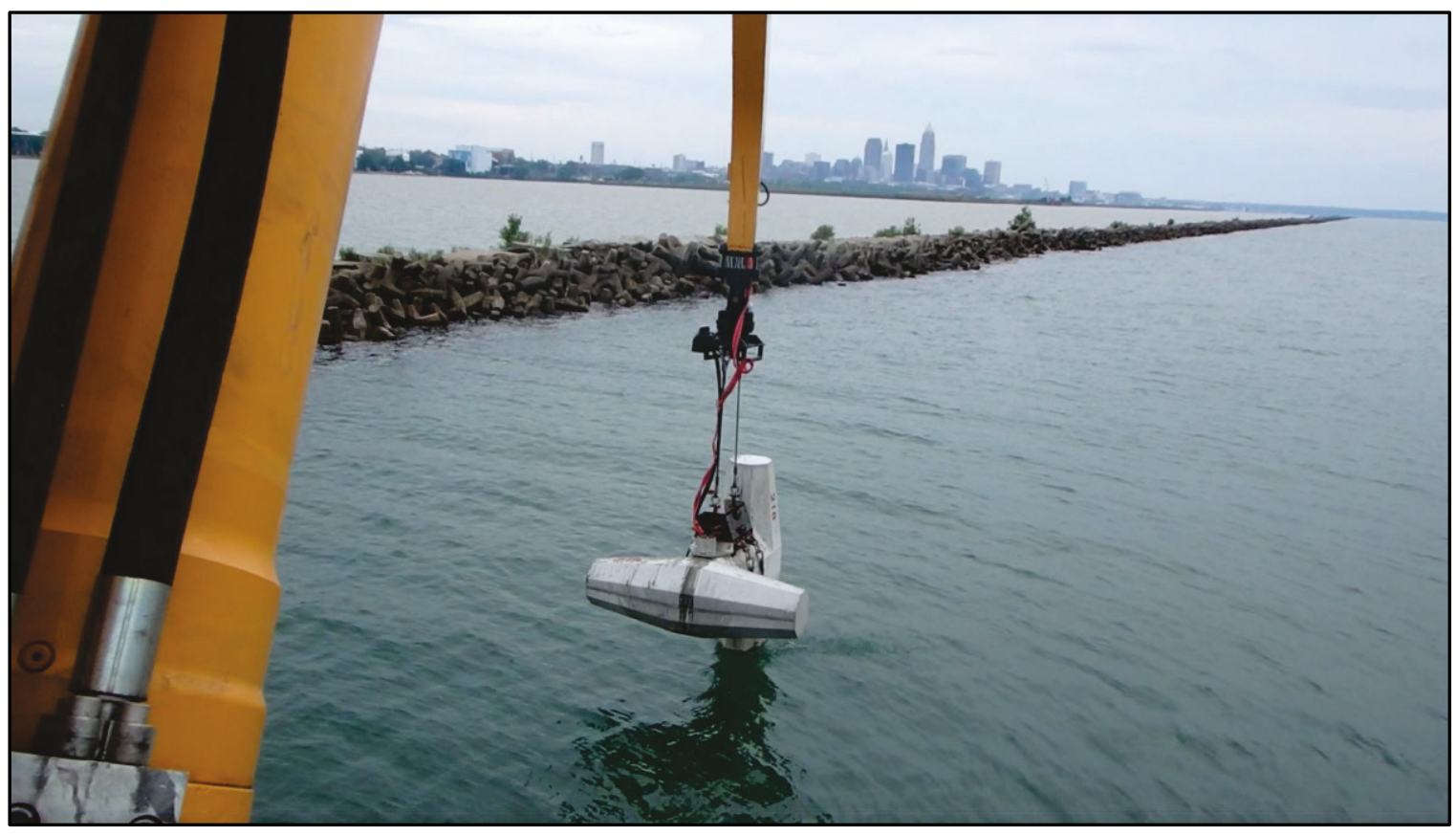

Figure 4-12. Cleveland dolos lifting mechanism returns for next dolos (video time 4:17 min:sec).

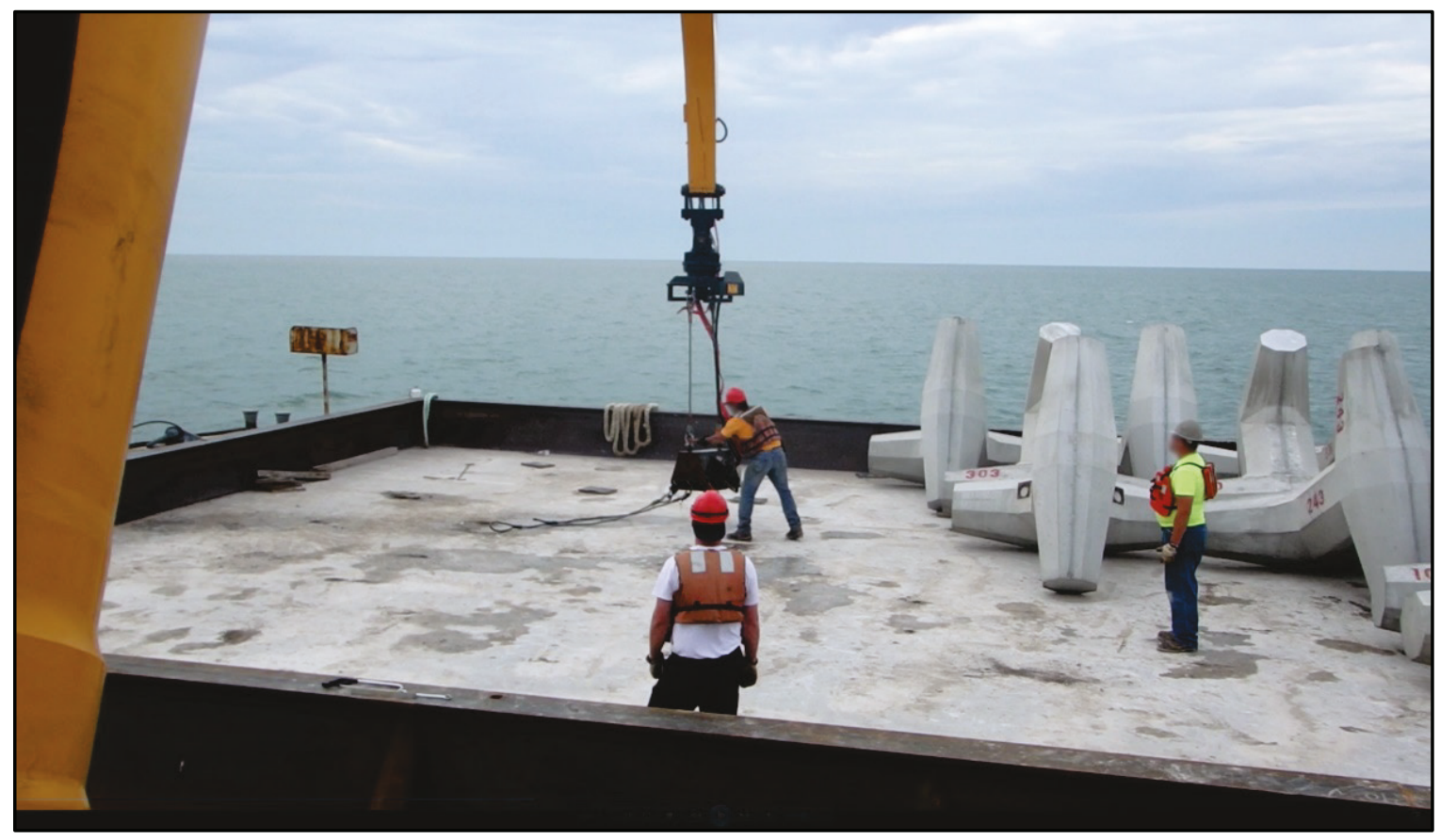


Figure 4-13. Next Cleveland dolos is being lifted for placement (video time 5:39 min:sec).

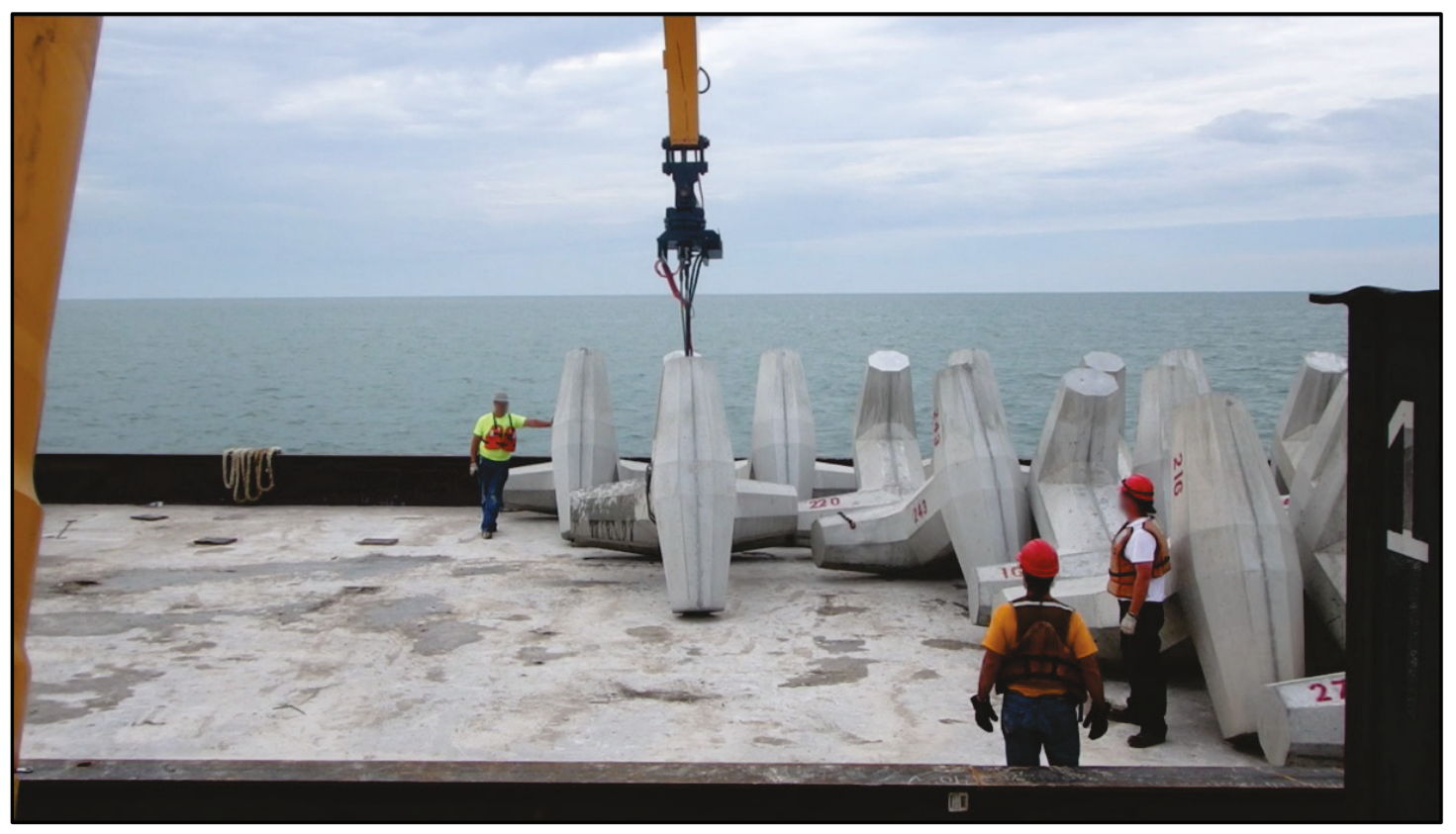

In addition to the crane operator who was placing the dolosse, a Placement Plan Control Specialist was assigned to execute the placement plan by monitoring dolosse placement densities, updating the reporting form as dolos were being placed for each $25 \mathrm{ft}$ length of repair, providing a georeferenced properly scaled plan view electronic image showing all dolosse placed that day and any photographs taken, providing daily files for $3 \mathrm{D}$ viewing where all dolosse were placed, and performing any other duties that might increase productivity and quality of dolosse placement. During the Cleveland project, the specialist was seated adjacent to the crane operator and had his own computer screen showing placement of the dolosse (Figure 4-14). 
Figure 4-14. Placing Cleveland dolos.

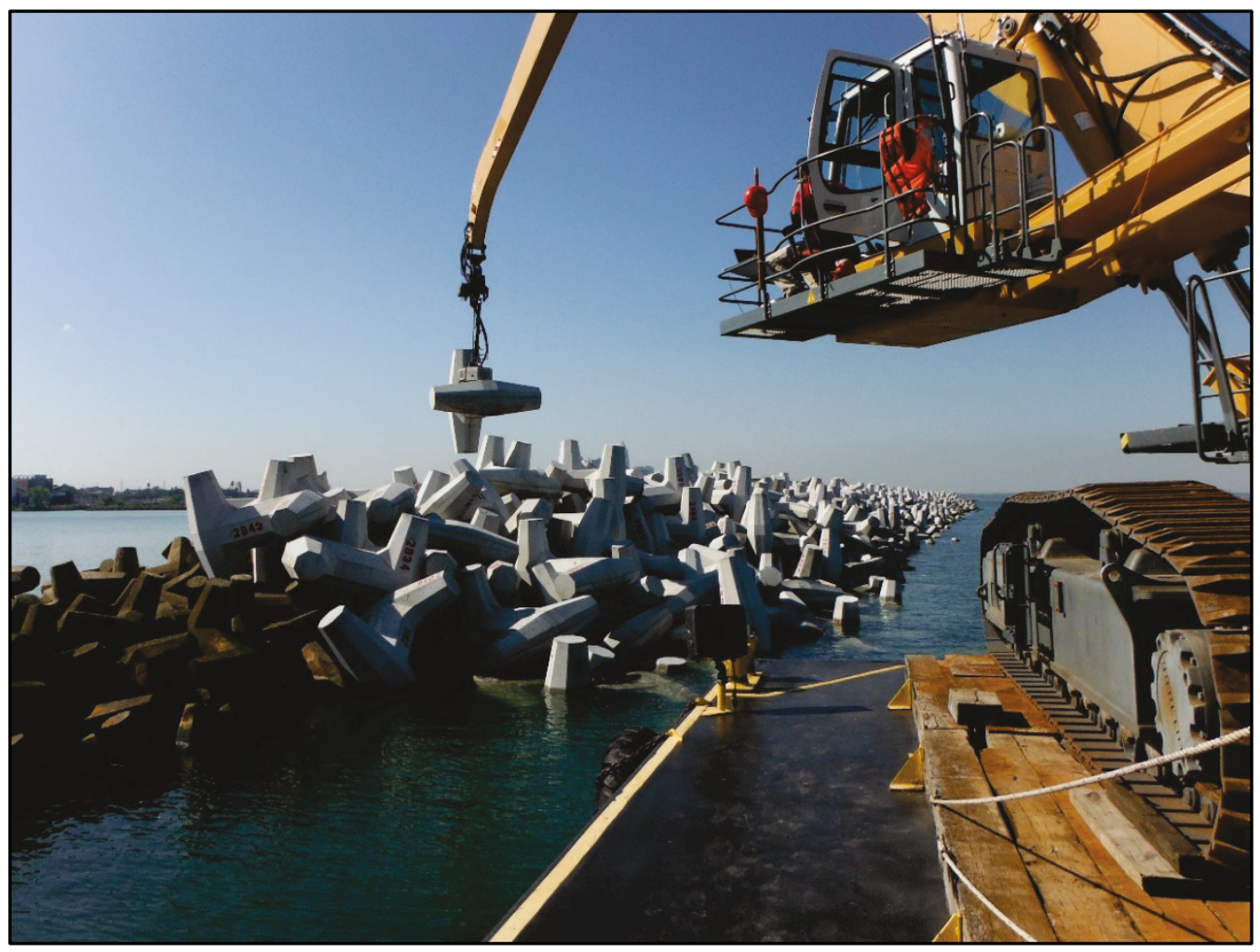

For the Oswego dolosse, the contractor elected to use cables with the BIB temporarily attached to the dolosse with plastic pins (Figure 4-15 and Figure 4-16).

Figure 4-15. Oswego dolos lifting arrangement.

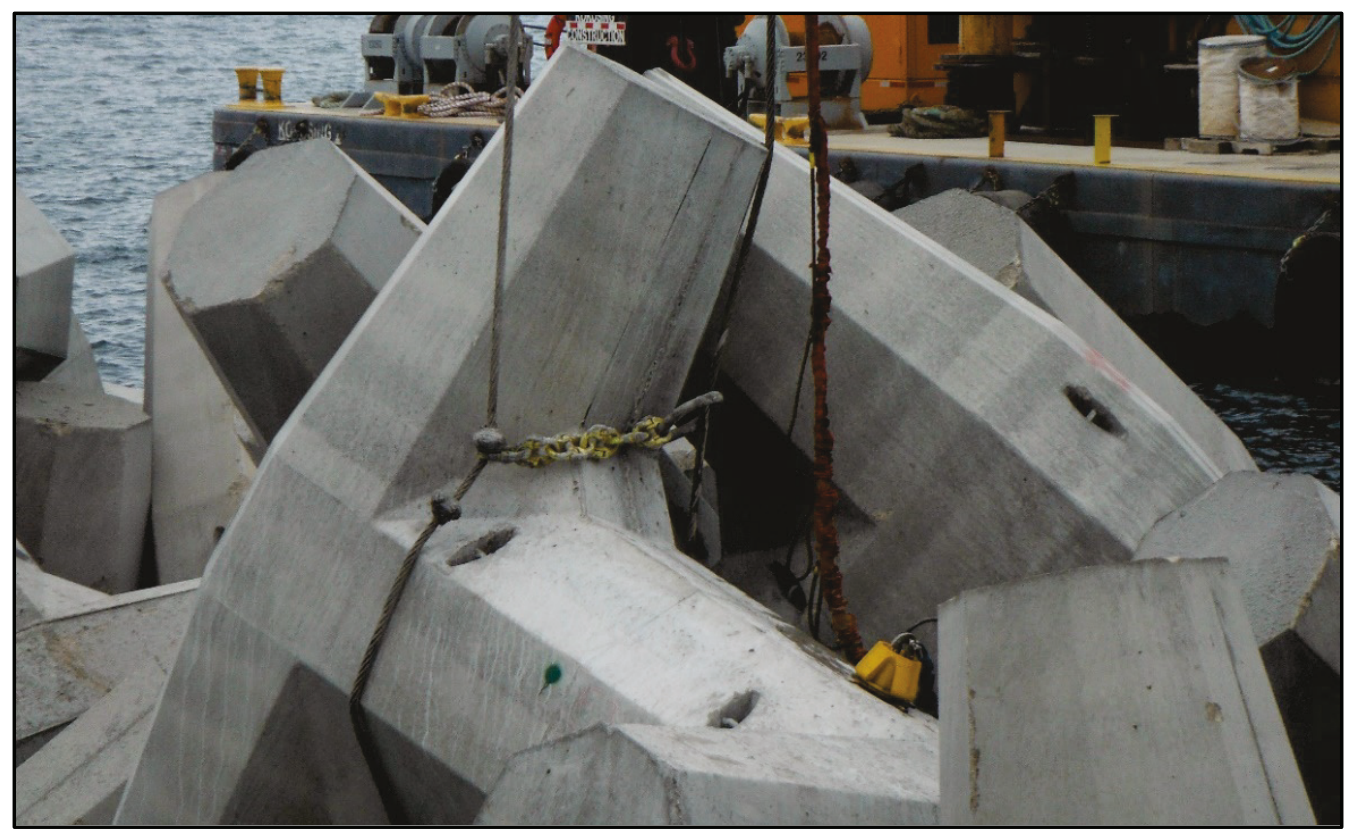


Figure 4-16. Oswego dolos lifting arrangement.

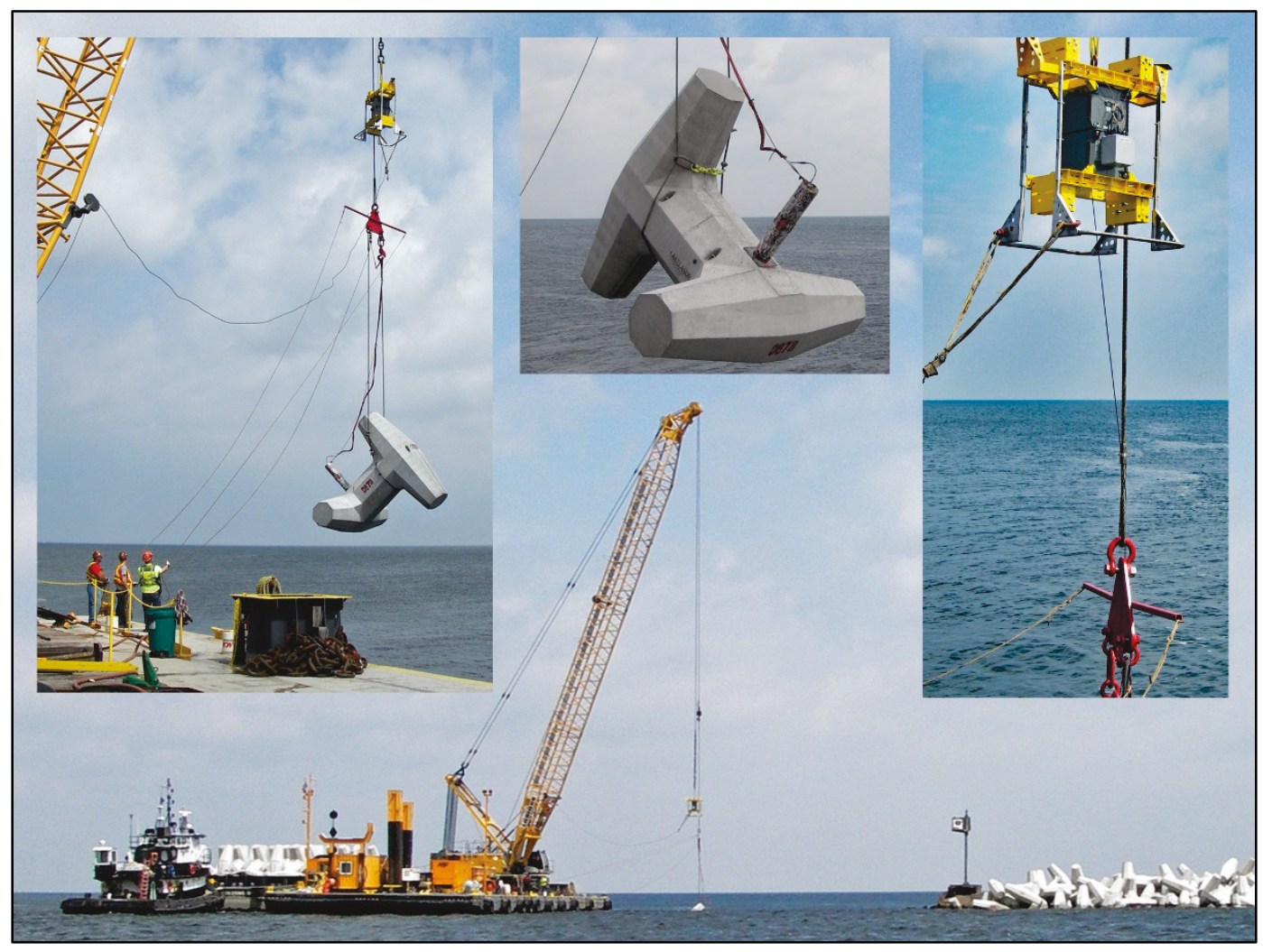

Despite significant project planning and communication among parties to avoid unexpected complications during placement, a complication still arose. An unexpected problem with the Oswego AUPPS arose with the steel reinforcement within the dolosse interfering with the attitude sensor (electromagnetic compass) in the BIB, requiring the sensor to be calibrated for each unit to show actual pitch and roll. The contractor worked on solutions to insulate the BIB and finally settled on placing the BIB on a removable stanchion (riser pipe). This may be seen in Figure 4-16, center top photo. Due to the potential project delays from having to recalibrate the BIB on each dolosse, it was agreed to recalibrate only those at the base that formed the specially oriented toe. Despite this setback, the AUPPS accurately showed the center of gravity for density computation, and by placing the dolosse at random orientations, good interlocking was assured.

The contractor supplied laptops during the construction period to the government with the VISIBLOC software, which allowed for $3 \mathrm{D}$ visualization of the placed dolosse and confirmation of the placement, orientation, and density. Prior to the onset of construction, the contractor, the U.S. Army Corps of Engineers (USACE), and design personnel received training on the use of the VISIBLOC software from a MESURiS company 
representative. During construction, USACE designers were given VISIBLOC software files for the actual placement of the dolosse so that dolos placement could be reviewed as construction progressed. Figure 4-17 through Figure 4-20 present a sequence of views captured from a VISIBLOC video, which shows a dolos being placed on the Cleveland East Breakwater. The upper-left menu presents the dolos information, the current position, the planned location, and the difference from the current and planned position of the dolos. The actual track that the dolos followed is shown by the white line. The dolos changed color depending upon the proximity to the target location. The view orientation could be changed using the menu in the upper right.

Figure 4-17. Cleveland dolos VISIBLOC placement view.

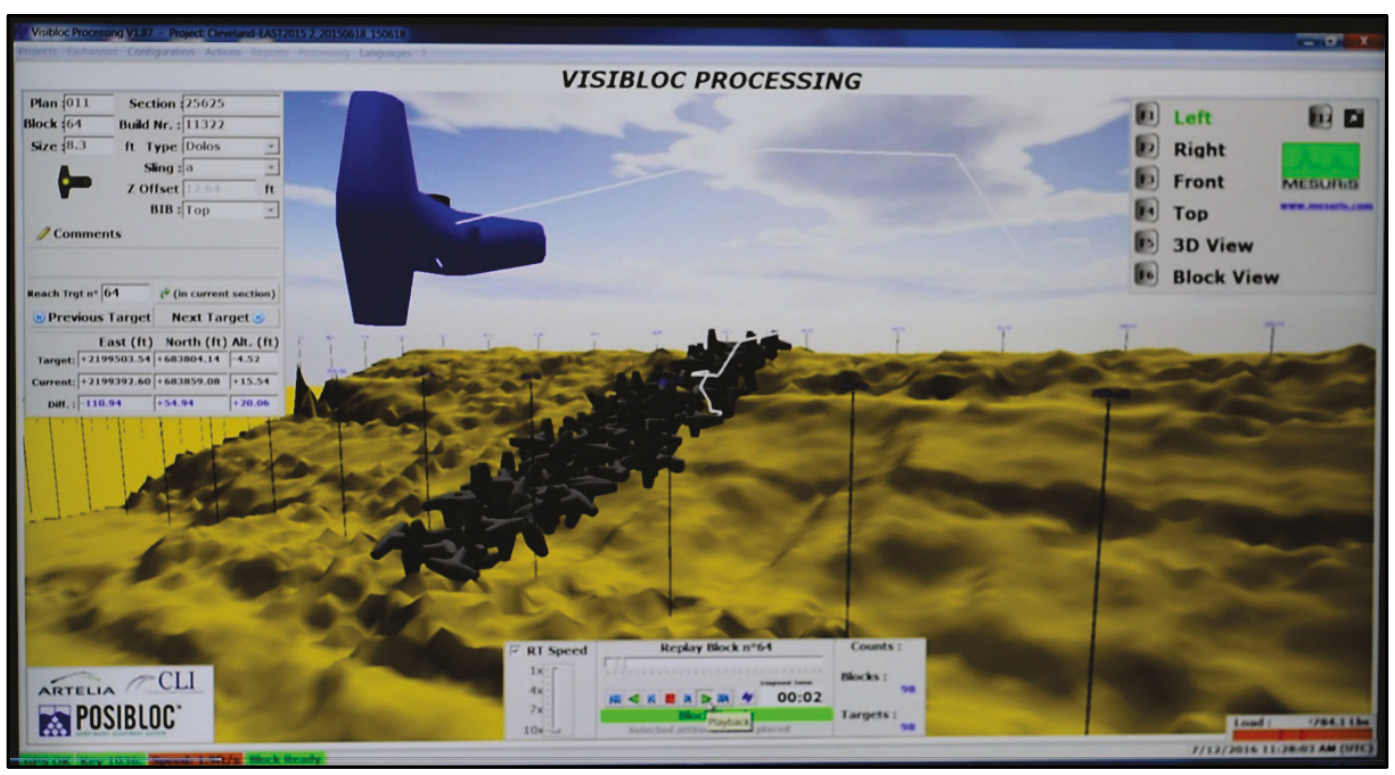


Figure 4-18. Cleveland dolos VISIBLOC placement view.

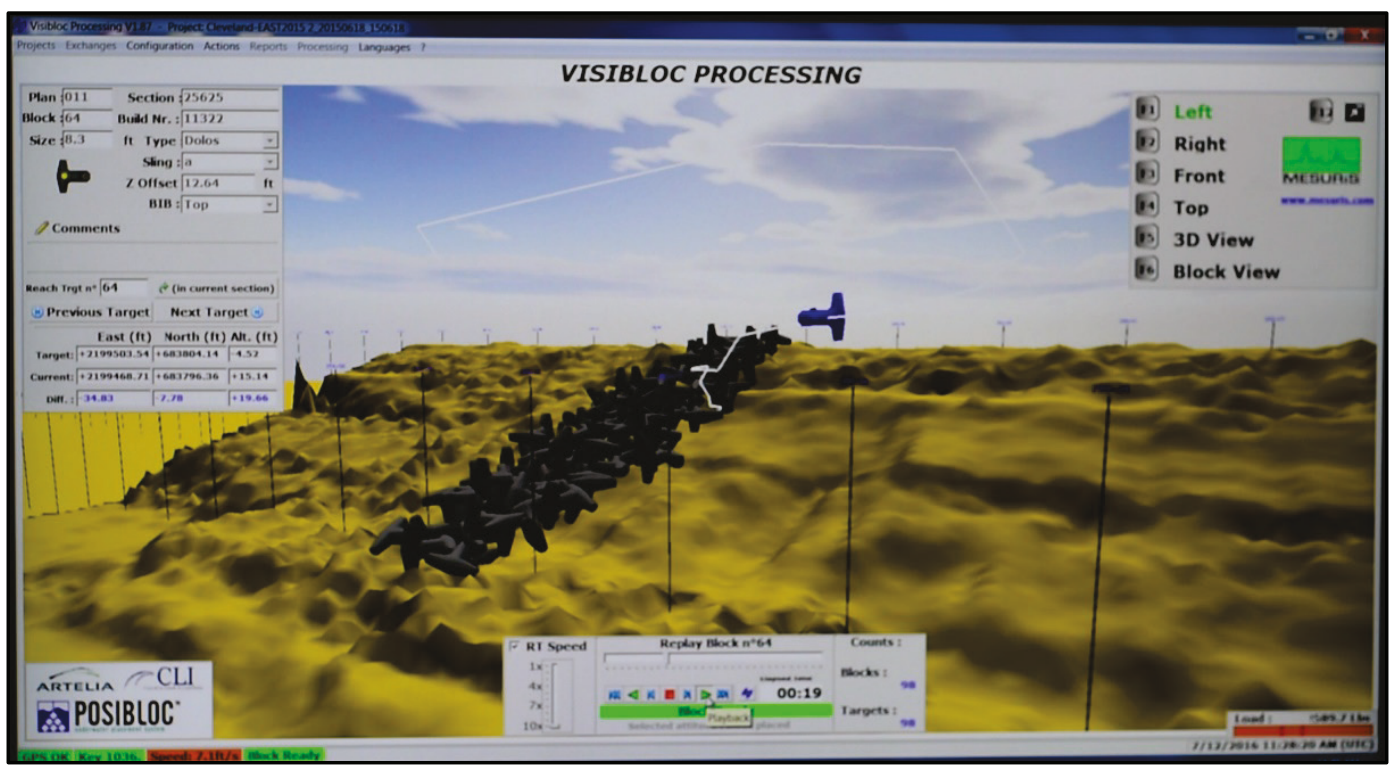

Figure 4-19. Cleveland dolos VISIBLOC placement view.

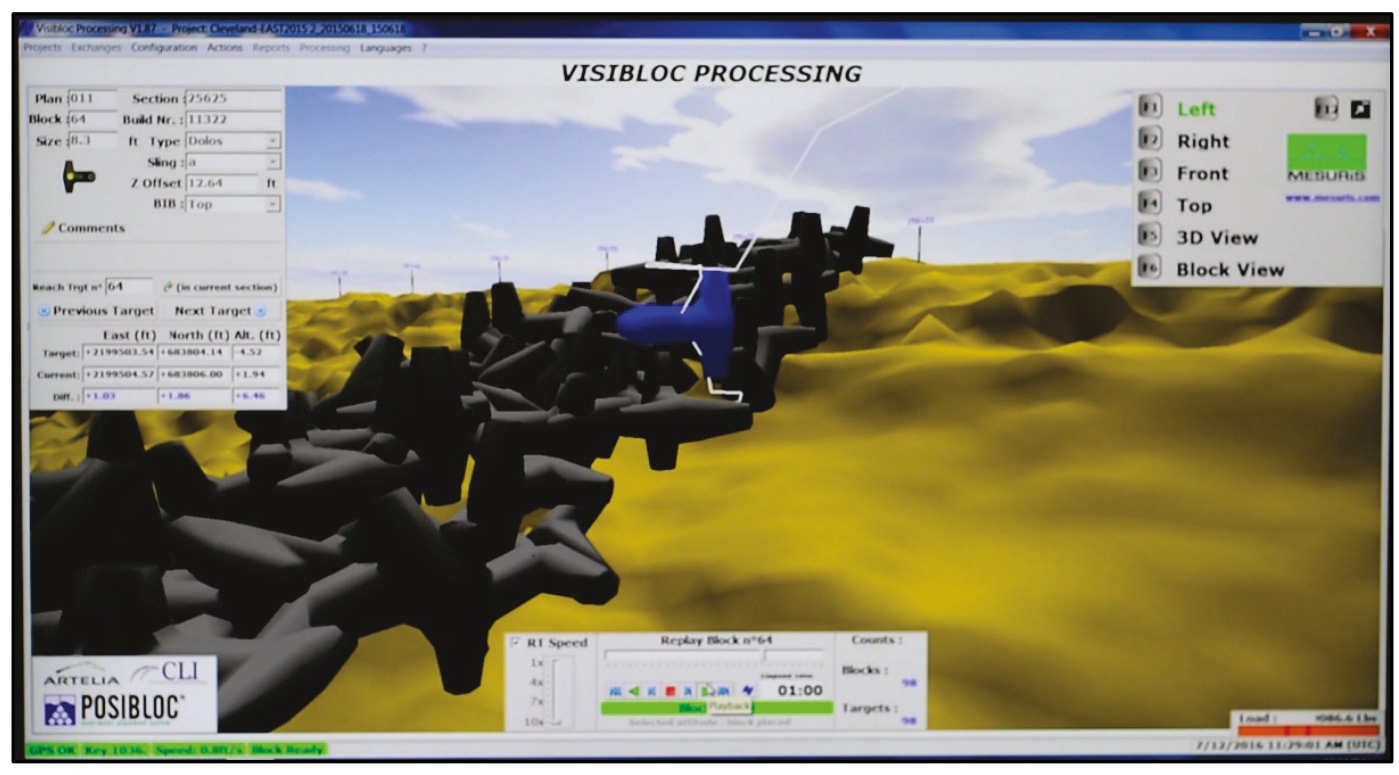


Figure 4-20. Cleveland dolos VISIBLOC placement view.

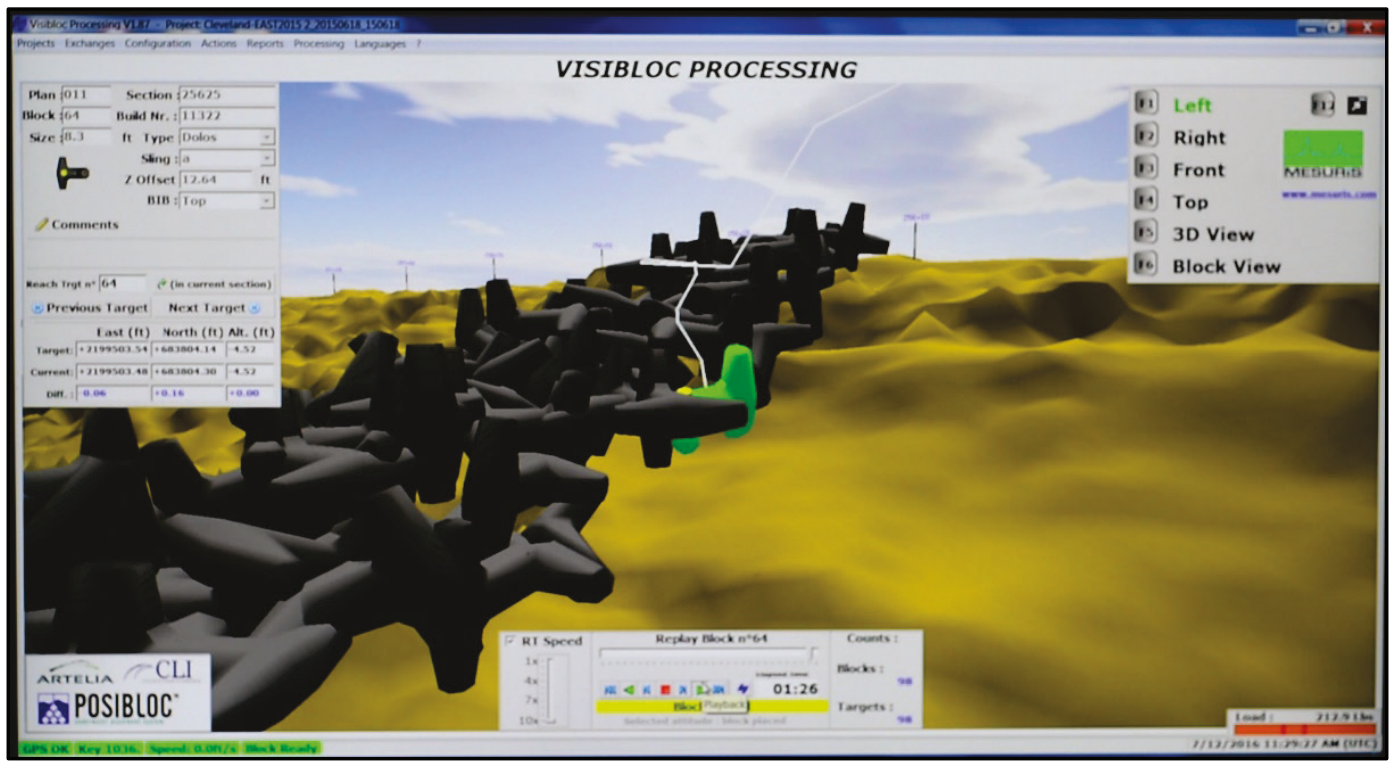

\section{Dolos placement rate}

Mesuris ${ }^{1}$ indicated that POSIBLOC allows placement of an average of 60 to 80 blocks every $10 \mathrm{hr}$ whatever the size of the unit. The quality of placement is perfectly controlled, with no risk of removal for noncompliance. The system was reported to result in a reduction in the placement duration. USACE (2014e) states that the industry standard for full production placement rate for concrete armor is $8 \mathrm{units} / \mathrm{hr}$, assuming that the contractor has no constraints. It was recommended to be conservative and assume 4 to 6 units/hr. Placement rate could be as slow as a few per day during the first week. Poor slinging technique is a hindrance. Releasing the dolos must be done so that the sling does not bind and then lift the unit. Chains tend to get stuck in the layer resulting in lifting on release. A claw-type apparatus also tends to bind. Fabric slings or wire ropes are the most common.

\section{Cleveland dolos placement rate}

The Cleveland East Breakwater repair required the placement of 18,259 6.5-ton dolosse, which occurred over two construction seasons. Minimal breakage during handling and placement occurred and resulted in only four dolosse to be deemed unsuitable. During the 2015 season, o9 June to 16 November, which spanned 161 calendar days, 6,919 dolosse were placed

\footnotetext{
1 MESURIS, 37 rue de l'Océan - 56470 SAINT-PHILIBERT - FRANCE,

http://www.mesuris.com/en/systems-2/posibloc.html
} 
for an average of 43 dolosse/day. However, during that time period, the contractor placed dolosse only during 74 of those days suggesting an average rate of 93 dolosse/day. During the 2016 season, 24 April to 07 November, which spanned 198 calendar days, 11,340 dolosse were placed for an average of 57 dolosse/day. However, during that time period, the contractor placed dolosse only during 87 of those days suggesting an average rate of 130 dolosse/day. The minimum placement rate occurred on the first day when only 8 dolosse were placed, and the maximum placement occurred when 227 dolosse were placed. Figure 4-21 presents the daily placement rate. Table 4-2 presents the Cleveland dolos daily placement rate descriptive statistics.

Figure 4-21. Cleveland 6.5-ton dolos placement rate.

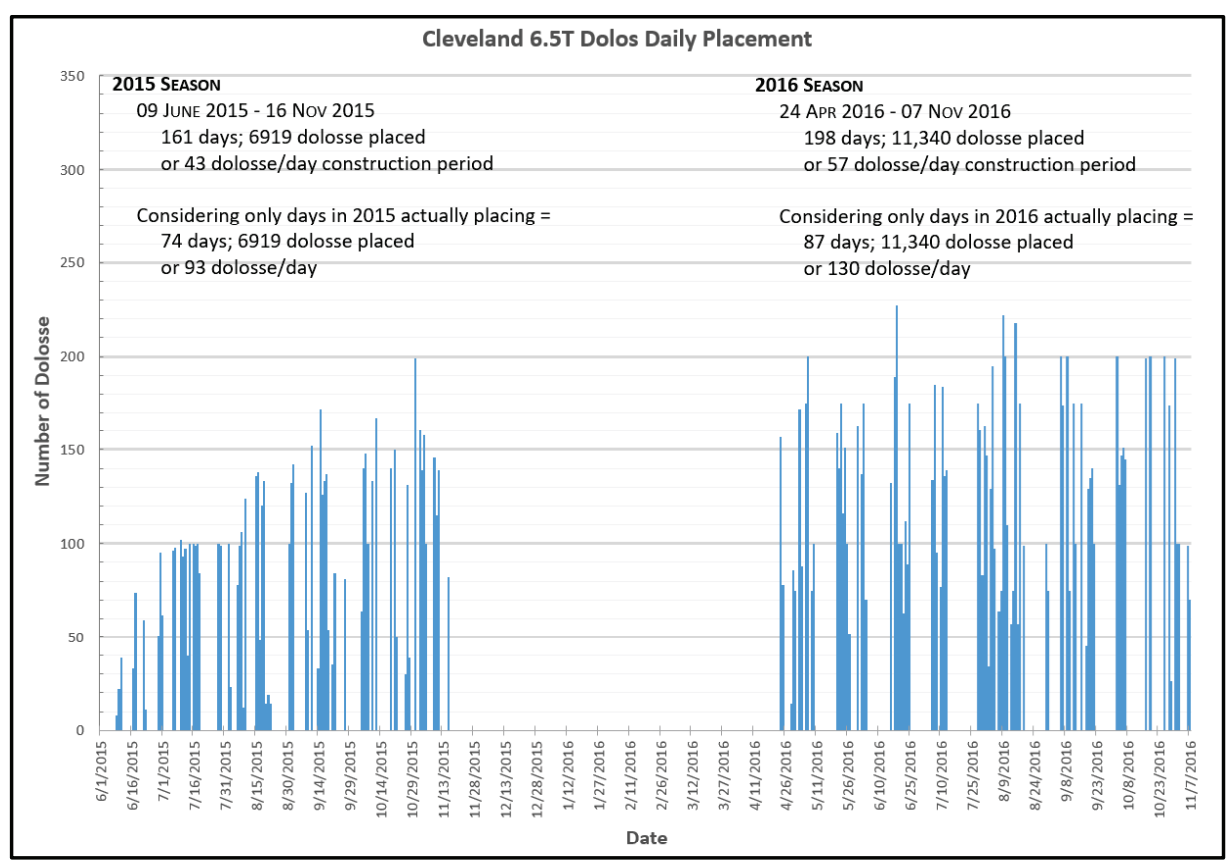


Table 4-2. Cleveland 6.5-ton dolos daily placement rate statistics.

\begin{tabular}{|l|c|}
\hline Mean & 113 \\
\hline Standard Error & 4 \\
\hline Median & 100 \\
\hline Mode & 100 \\
\hline Standard Deviation & 52 \\
\hline Sample Variance & 2,756 \\
\hline Kurtosis & -1 \\
\hline Skewness & 0 \\
\hline Range & 219 \\
\hline Minimum & 8 \\
\hline Maximum & 227 \\
\hline Sum & 18,214 \\
\hline Count & 161 \\
\hline
\end{tabular}

\section{Oswego dolos placement rate}

The Oswego Detached Breakwater repair required the placement of 973 16-ton dolosse during one construction season. During the period 25 June to 17 September 2015, which spanned 88 calendar days, 973 dolosse were placed for an average of 11 dolosse/day. However, during that time period, the contractor placed dolosse only during 39 of those days, suggesting an average rate of 25 dolosse/day. The minimum placement rate occurred on the first day when only 1 dolos was placed, and the maximum placement occurred on the next-to-last day when 54 dolosse were placed. Figure 4-22 presents the daily placement rate. 
Figure 4-22. Oswego 16-ton dolos placement rate.

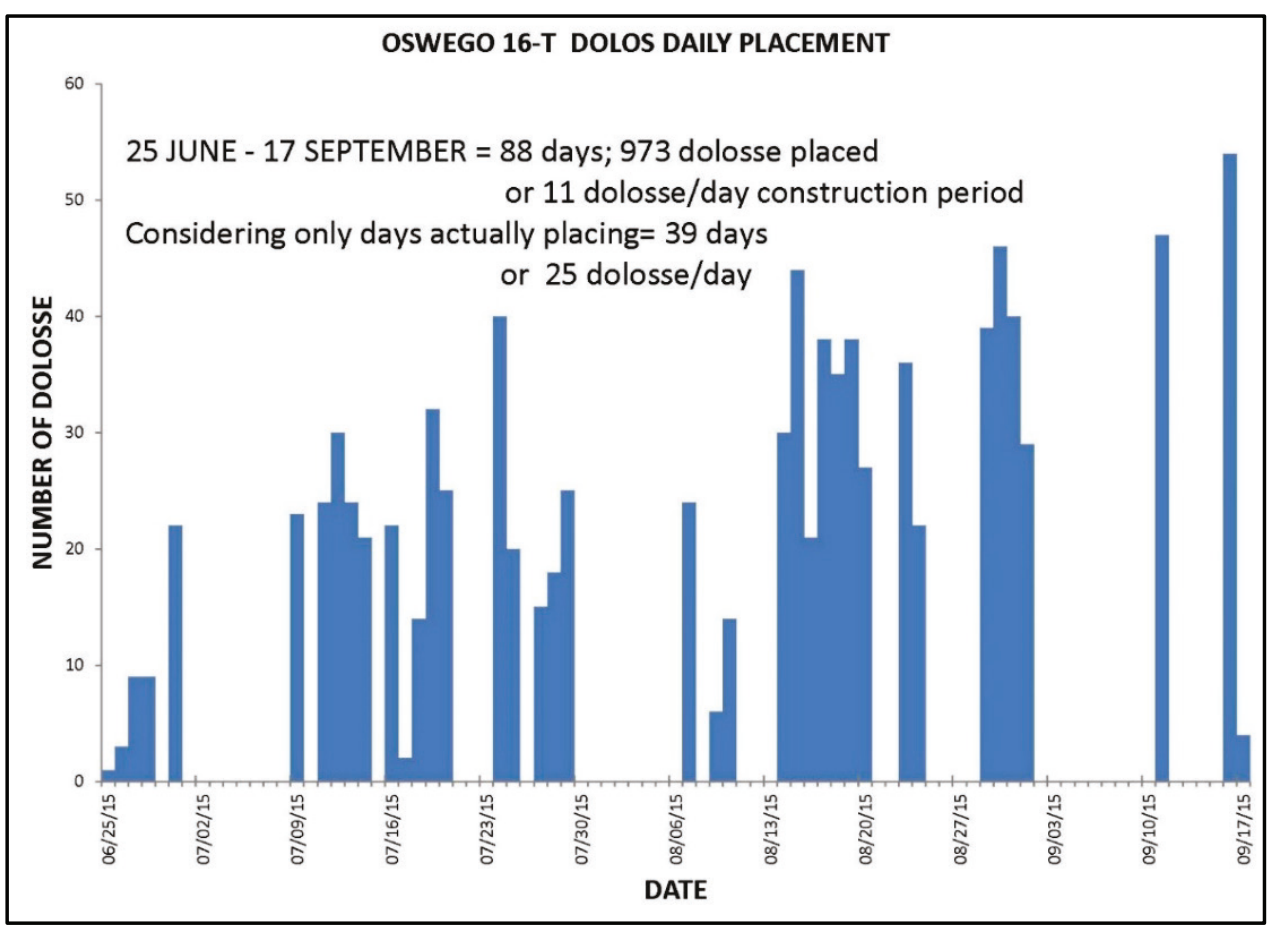




\section{Summary}

\section{Background}

Hurricane Sandy caused extensive damage to federal harbor structures on the Great Lakes. Extensive damage occurred along the eastern 4,400 ft of the Cleveland East Breakwater on Lake Erie, which had been repaired between 1979 and 1980 with 2-ton dolos armor units. Damage also occurred on the $850 \mathrm{ft}$ Oswego Detached Breakwater on Lake Ontario, which is a laid-up cut stone structure built in 1958-1960. Dolosse were selected to repair both structures due to the presence of dolos on the Cleveland East Breakwater and the large design wave for the Oswego Detached Breakwater.

\section{Dolos design}

The Cleveland East Breakwater repair called for the placement of 18,259 6.5-ton unreinforced dolosse. To produce such a large number within the 2-year construction window, 54 forms were used. The mix design was modified to allow the units to be safely removed from the forms each half day (12 hr).

The Oswego Detached Breakwater required 973 16-ton steel reinforced dolosse. The steel reinforcement cages and casting of the dolosse were done inside using 8 forms. The concrete mix was designed to allow the dolosse to be removed from the forms each day ( $24 \mathrm{hr}$ ). The contractor requested a sight change to the dolos shape by chamfering the inner facet of the vertical fluke (orientation when casting) to aid in the removal from the form.

As the use of dolos units is rare in the Great Lakes, it was deemed important to construct a scale model of the typical section for each project to acquaint the potential bidders with the proposed repair. The models were scaled based upon the number and size of available model dolosse supplied by ERDC. The models resided at the respective project office, allowing the contractors to deconstruct and reconstruct the model, giving them a better sense of the placement process and visually demonstrating proper interlocking. 


\section{Dolos production}

Prior to full production, the contractors were required to confirm the creation of a quality dolos, by producing sample dolosse. These dolosse were subjected to visual inspection, strength testing, and destructive testing.

For the Cleveland dolosse, for the manufacturer to safely remove the dolosse from the forms each half day ( $12 \mathrm{hr}$ ), the mix was modified to result in higher early strength. The mean 28-day compressive strength of $6,562 \mathrm{lb} / \mathrm{in}^{2}{ }^{2}$ was $130 \%$ of the minimum required. The actual mean 28 -day flexural strength of $1,192 \mathrm{lb} / \mathrm{in}^{2}{ }^{2}$ was more than double the minimum required tensile strength of $500 \mathrm{lb} / \mathrm{in}^{2}$. The resulting unit weight of $147 \mathrm{lb} / \mathrm{ft}^{3}$ was slightly higher than the design unit weight of $140 \mathrm{lb} / \mathrm{ft}^{3}$, resulting in an actual dolos weight of 6.8 tons.

For the Oswego dolosse, for the manufacturer to safely remove from the forms each day ( $24 \mathrm{hr}$ ), the mix was modified to result in a higher early strength. For the 1-day compressive strengths, $26.7 \%$ of the tests were greater than the minimum required 28 -day strength of 5,000 lb/in. ${ }^{2}, 99.7 \%$ were greater than the minimum by the eighth day, and all test results were greater than the minimum requirement by 28 days. The quality assurance testing indicated an average 28-day compressive strength of $8,58 \mathrm{olb} / \mathrm{in} .^{2}$, with test results ranging from 7,735 to $9,690 \mathrm{lb} / \mathrm{in}^{2}{ }^{2}$.

\section{Dolos placement}

In addition to using quality materials, excellent placement is required to ensure a quality project. Since most of the dolos placement occurs underwater and is not visible, it was necessary to specify a method that would guarantee proper density, even distribution, and good interlocking (individual dolos orientation randomness) of the dolosse. Prior to fullscale placement operations, a $25 \mathrm{ft}$ length of breakwater was completed as a test of the proper placement and maximum interlocking of the dolosse.

Contractors for both projects used the POSIBLOC system developed by MESURiS, which is a topographical 3D system for optimum placement control of armor units above or below water. The system combines RTK, GPS, and GLONASS positioning technologies and attitude sensors to produce a $3 \mathrm{D}$ image of the dolos units being placed in real time and was capable of guiding the crane operator in placing dolosse in their designated 
positions with interlocking control. A recoverable attitude sensor (BIB) was attached to the armor unit prior to placement with three small plastic pins. During placement, the crane operator and the Placement Plan Control Specialist could see the $3 \mathrm{D}$ image of the unit being placed in real time, in addition to being able to see previously placed units and the target points for dolosse not yet placed. A position indicator showed the $x, y, z$ differences between the real-time and target coordinates.

Coupled with the VISIBLOC software, each dolos trajectory was monitored and recorded, out-of-profile units detected, the placement density for any selected area determined, screenshots of dolosse in any direction generated, the center of gravity coordinates stored for each placed dolos unit along with attitude and conditions of placing (positioning quality, speed, first or last attitude selected), and the time and date were stored for each dolos unit placed.

The Cleveland East Breakwater repair occurred over two construction seasons. During the 2015 season, o9 June to 16 November, the contractor placed 6,919 dolosse during 74 of those days, suggesting an average rate of 93 dolosse/day. During the 2016 season, 24 April to 07 November, the contractor placed 11,340 dolosse during 87 of those days, suggesting an average rate of 130 dolosse/day. The minimum placement rate occurred on the first day when only 8 dolosse were placed, and the maximum placement occurred when 227 dolosse were placed. Breakage of dolos units was minimal during the handling and placement and resulted in four dolosse to be unsuitable.

The Oswego Detached Breakwater repair occurred over one construction season. During the 2015 season, 25 June to 17 September, the contractor placed 973 dolosse during 39 of those days, suggesting an average rate of 25 dolosse/day. The minimum placement rate occurred on the first day when only 1 dolos was placed, and the maximum placement occurred on the next-to-last day when 54 dolosse were placed.

\section{Lessons learned}

An unexpected problem with the Oswego AUPPS arose with the steel reinforcement within the dolosse interfering with the attitude sensor (electromagnetic compass) in the BIB, requiring the sensor to be calibrated for each unit to show actual pitch and roll. The contractor worked on solutions to insulate the BIB and finally settled on placing the 
$\mathrm{BIB}$ on a removable stanchion (riser pipe). Due to the potential project delays from having to recalibrate the BIB on each dolosse, it was agreed to recalibrate only those at the base that formed the specially oriented toe. Knowing this, an alternative placement method using multibeam sonar and lidar in combination with the CodaOctopus software that created an image of the dolos using three axial points $(x, y, z)$ may have been more appropriate for placement. Despite this setback, the AUPPS accurately showed the center of gravity for density computation, and by placing the dolosse at random orientations, good interlocking was assured.

\section{Future monitoring recommendations}

To correlate the degree of settlement, tilting, and rocking of each dolos under environmental forces to which it will be subjected, periodic surveys of the Cleveland East Breakwater and the Oswego Detached Breakwater repairs should be conducted on a 3 - to 5 -year interval. This will provide data for predicting future dolos movement to estimate remaining useful life of the structure, based on the probability of future storm events as projected from historical events. The time-dependent damage modeling approach being developed by the MCNP Work Unit "Reliability Analysis of Coastal Structures" allows for the assessment of structure performance throughout the structure lifetime for a wide range of forcing and design conditions, knowledge that is of particular interest for asset-management funding prioritization.

Recently developed technology and acquisition system allows for obtaining high resolution lidar terrain data coincident with red, green, and blue imagery utilizing an unmanned aerial system that is capable of acquiring high-resolution $3 \mathrm{D}$ topography. A high-resolution point cloud consisting of billions of points can be generated with an accuracy of $2 \mathrm{~cm}$. The ability of an unmanned lidar survey system to make multiple passes and approach from various angles enables the data collection to fill in data shadows that previously have occurred during tripod lidar surveys (TLS) of breakwaters due to the stationary, down-looking vantage point of the TLS instrument from the top of the breakwaters. 


\section{References}

ASTM International (ASTM). 2010. Standard Test Method for Air Content of Freshly Mixed Concrete by the Pressure Method. C231/C231M. West Conshohocken, PA: American Society for Testing Materials.

ASTM. 2011. Standard Test Method for Temperature of Freshly Mixed HydraulicCement Concrete. C1064/C1064M. West Conshohocken, PA: American Society for Testing Materials.

ASTM. 2012a. Standard Test Method for Density (Unit Weight), Yield, and Air Content (Gravimetric) of Concrete. C138/C138M. West Conshohocken, PA: American Society for Testing Materials.

ASTM. 2012b. Standard Test Method for Slump of Hydraulic-Cement Concrete. C143/C143M. West Conshohocken, PA: American Society for Testing Materials.

ASTM. 2012c. Standard Test Method for Air Content of Freshly Mixed Concrete by the Volumetric Method. C173/C173M. West Conshohocken, PA: American Society for Testing Materials.

ASTM. 2012d. Standard Practice for Making and Curing Concrete Test Specimens in theLaboratory. C192/C192M. West Conshohocken, PA: American Society for Testing Materials.

ASTM. 2012e. Standard Practice for Making and Curing Concrete Test Specimens in the Field. $\mathrm{C}_{31} / \mathrm{C}_{31} \mathrm{M}$. West Conshohocken, PA: American Society for Testing Materials.

ASTM. 2012f. Standard Test Method for Compressive Strength of Cylindrical Concrete Specimens. C39/C39M. West Conshohocken, PA: American Society for Testing Materials.

ASTM. 2013. Standard Test Method for Flexural Strength of Concrete (Using Simple Beam with Third-Point Loading). C78/C78M. West Conshohocken, PA: American Society for Testing Materials.

Burcharth, H. F., and Z. Liu. 1992. "Design of Dolos Armour Units." In Proceedings of the 23rd International Coastal Engineering Conference. American Society of Civil Engineers (1): 1053-1066.

Carver, R. D. and M. S. Heimbaugh. 1989. Stability of Stone and Dolos-Armored RubbleMound Breakwater Heads Subjected to Breaking and Nonbreaking Waves with No Overtopping. Technical Report CERC-89-4. Vicksburg, MS: U.S. Army Engineer Research and Development Center.

Hudson, R. Y. 1958. Design of Quarry-Stone Cover Layers for Rubble-Mound Breakwaters: Hydraulic Laboratory Investigation. Research Report 2-2. Vicksburg, MS: U.S. Army Engineer Waterways Experiment Station. 
Lin, L., Z. Demirbilek, H. Mase, J. Zheng, and F. Yamada. 2008. CMS-Wave: A Nearshore Spectral Wave Processes Model for Coastal Inlets and Navigation Projects. ERDC/CHL TR-08-13. Vicksburg, MS: U.S. Army Engineer Research and Development Center.

Mouquet, A. 2009. "Armour Unit Placement and Positioning in 3D Real Time.” In Coast, Marine Stuctures, and Breakwaters. Rennes, France: Mesuris Marine Systems.

U.S. Army Corps of Engineers (USACE). 1984. Shore Protection Manual. $4^{\text {th }}$ Edition. Vicksburg, MS: U.S. Army Engineer Waterways Experiment Station.

USACE. 1993. Design Water Level Determination on the Great Lakes. Detroit, MI: U.S. Army Corps of Engineers.

USACE. 2011. Coastal Engineering Manual. Part VI, Chapter 5, "Fundamentals of Design.” EM 1110-2-1100. Vicksburg, MS: U.S. Army Corps of Engineers. https: / $/$ www.publications. usace. army. mil/LinkClick. aspx?fileticket $=$ uvxhTbX2AhA\%3d\&tabid=16 439\&portalid $=76 \& \mathrm{mid}=43544$.

USACE. 2014a. Wave Information Study. Vicksburg, MS: U.S. Army Engineer Research and Development Center. http://wis.usace.army.mil/hindcasts.shtml?dmn=lakesWIS.

USACE. 2014b. Cleveland Harbor, Ohio East Breakwater Repair (Dolosse Section) due to Damage Caused by Superstorm Sandy; Appendix A, Coastal Engineering. Buffalo, NY: U.S. Army Corps of Engineers.

USACE. 2014c. Oswego Harbor Detached Breakwater, NY Repairs Due to Damage Caused by Superstorm Sandy; Appendix A, Coastal Engineering. Buffalo, NY: U.S. Army Corps of Engineers.

USACE. 2014d. Oswego Harbor Detached Breakwater, NY Repairs Due to Damage Caused by Superstorm Sandy; Appendix B, Structural Engineering. Buffalo, NY: U.S. Army Corps of Engineers.

USACE. 2014e. Cleveland Harbor FY14 East Breakwater Repair (Dolosse): Cleveland, Ohio; Documents, Plans, and Specifications. W912P4-14-B-0012. Buffalo, NY: U.S. Army Corps of Engineers.

USACE. 2014f. Oswego Harbor FY14 Detached Wall Repair (Stone and Dolosse): Oswego, New York; Plans and Specifications. W912P4-14-C-0021. Buffalo, NY: U.S. Army Corps of Engineers. 


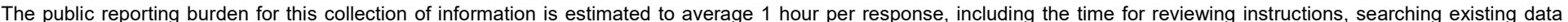

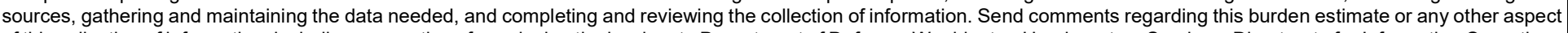

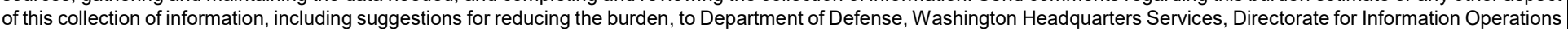

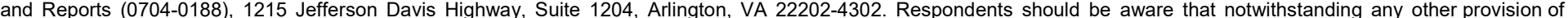
law, no person shall be subject to any penalty for failing to comply with a collection of information if it does not display a currently valid OMB control number.

PLEASE DO NOT RETURN YOUR FORM TO THE ABOVE ADDRESS.

\begin{tabular}{|l|l|l|l}
\hline 1. REPORT DATE & 2. REPORT TYPE & 3. DATES COVERED (FrOm - To)
\end{tabular}

\begin{tabular}{l|l}
\hline June 2018 & Final Report
\end{tabular}

\section{TITLE AND SUBTITLE}

5a. CONTRACT NUMBER

Use of Dolos Armor Units to Repair Hurricane Sandy-Damaged Great Lakes Harbor Breakwaters

5b. GRANT NUMBER 5c. PROGRAM ELEMENT NUMBER

5d. PROJECT NUMBER

5e. TASK NUMBER

5f. WORK UNIT NUMBER

A1060

8. PERFORMING ORGANIZATION REPORT NUMBER

Development Center Coastal and Hydraulics Laboratory 3909 Halls Ferry Road Vicksburg, MS 39180-6199

\section{PERFORMING
ADDRESS(ES)}

U.S. Army Corps of Engineers

1776 Niagara Street

Buffalo, NY 14207-3199

\section{SPONSORING/MONITORING AGENCY NAME(S) AND ADDRESS(ES)}

U.S. Army Corps of Engineers

Washington, DC 20314-1000
ERDC/CHL TR-18-8

10. SPONSOR/MONITOR'S ACRONYM(S)

USACE

\section{SPONSOR/MONITOR'S REPORT} NUMBER(S)

\section{DISTRIBUTION/AVAILABILITY STATEMENT}

Approved for public release; distribution is unlimited.

\section{SUPPLEMENTARY NOTES}

\section{ABSTRACT}

After traveling up the eastern U.S. coastline, Hurricane Sandy made landfall on 29 October 2012 near Atlantic City, NJ, with winds of 80 $\mathrm{mph}$. The backside of the storm moved inland, bringing high winds and rain far into the nation's interior. No longer a hurricane, but termed Superstorm Sandy, the winds were generally from the north over the Great Lakes, extending as far west as Lake Michigan, causing extensive damage to several federal harbor structures especially in the Lower Great Lakes, including Cleveland East Breakwater on Lake Erie and Oswego Detached Breakwater on Lake Ontario. Concrete dolos armor units were selected to repair damage on these two structures. During 2015, 6,919 6.5-ton unreinforced dolosse were placed, and an additional 11,340 dolosse were placed in 2016 on the Cleveland East Breakwater. During 2015, 973 16-ton steel-reinforced dolosse were placed on the Oswego Detached Breakwater. The dolos design process, creation of the forms, strength testing, and placement are described and documented. Knowledge gained from this initial placement and from future periodic monitoring will correlate dolos movement with environmental forces. This information will be used for reliability analysis of coastal structures in determining remaining useful life for asset-management funding prioritizations.

\section{SUBJECT TERMS}

Armourstone, Breakwaters-Maintenance and repair, Concrete blocks, Great Lakes (North America), Hurricane Sandy, 2012

\begin{tabular}{|c|c|c|c|}
\hline \multicolumn{3}{|c|}{ 16. SECURITY CLASSIFICATION OF: } & \multirow{2}{*}{$\begin{array}{l}\text { 17. LIMITATION OF } \\
\text { ABSTRACT }\end{array}$} \\
\hline a. REPORT & b. ABSTRACT & c. THIS PAGE & \\
\hline Unclassified & Unclassified & Unclassified & SAR \\
\hline
\end{tabular}
18. NUMBER
OF PAGES

77 19a. NAME OF RESPONSIBLE PERSON Michael C. Mohr

19b. TELEPHONE NUMBER (Include area code) 563-582-1204 